Portland State University

PDXScholar

$12-4-1981$

\title{
Community Structure on the Urban Frontier: the Jews of Portland, Oregon, 1849-1887
}

Robert Scott Cline

Portland State University

Follow this and additional works at: https://pdxscholar.library.pdx.edu/open_access_etds

Part of the History Commons, and the Jewish Studies Commons

Let us know how access to this document benefits you.

Recommended Citation

Cline, Robert Scott, "Community Structure on the Urban Frontier: the Jews of Portland, Oregon, 1849-1887" (1981). Dissertations and Theses. Paper 77.

https://doi.org/10.15760/etd.77

This Thesis is brought to you for free and open access. It has been accepted for inclusion in Dissertations and Theses by an authorized administrator of PDXScholar. Please contact us if we can make this document more accessible: pdxscholar@pdx.edu. 
COMMUNITY STRUCTURE ON THE URBAN FRONTIER

THE JEWS OF PORTLAND, OREGON

$1849-1887$

by

ROBERT SCOTT CLINE

A thesis submitted in partial fulfillment of the requirements for the degree of

MASTER OF ARTS

in

HISTORY

Portland State University

(C) 1982 Robert Scott Cline 
TO THE OFFICE OF GRADUATE STUDIES AND RESEARCH:

The members of the Committee approve the thesis of Robert

Scott Cline presented December 4, 1981.

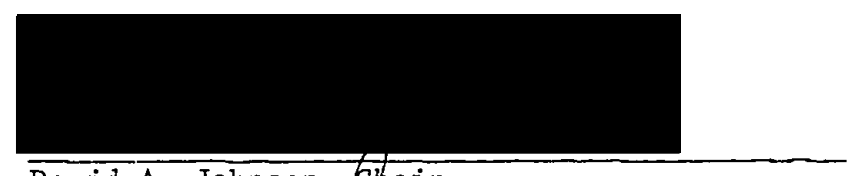

David A. Johnson, Chair

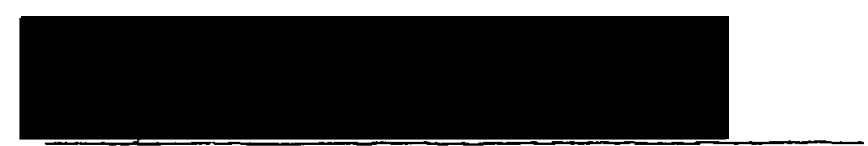

Victor C. Dahl
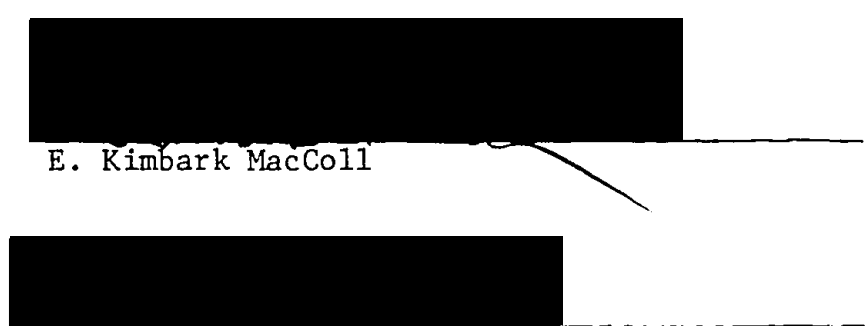

David Romey
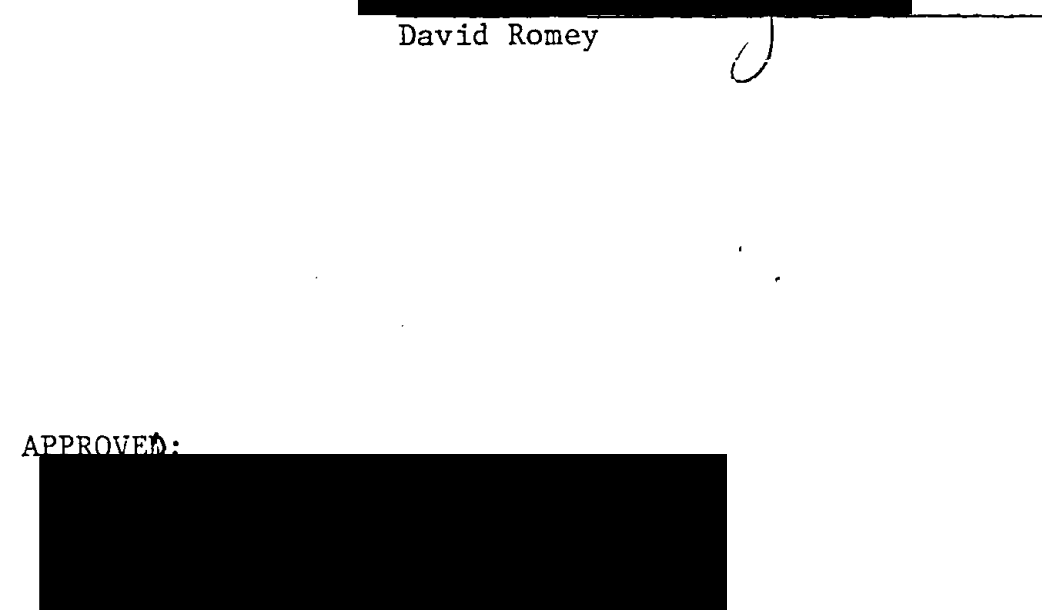

Frederick M. Nunn, Head, Department of History

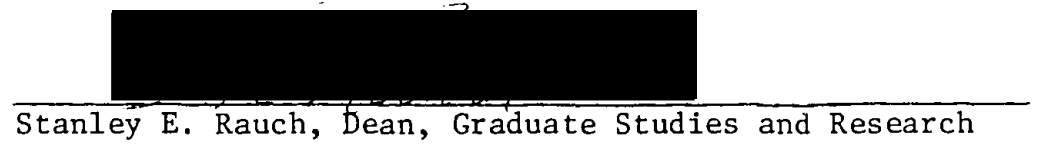


AN ABSTRACT OF THE THESIS OF Robert Scott Cline for the Master of Arts in History presented December 4, 1981.

Title: Community Structure on the Urban Frontier: The Jews of Portland, Oregon, 1849-1887.

APPROVED BY MEMBERS OF THE THESIS COMMITTEE:

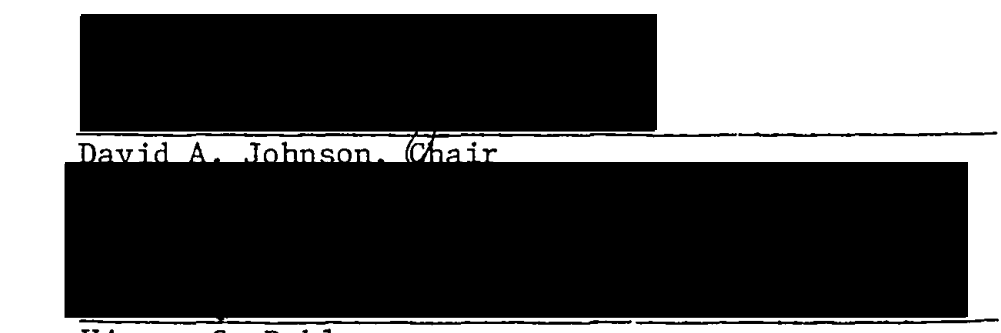
Victor C. Dah1

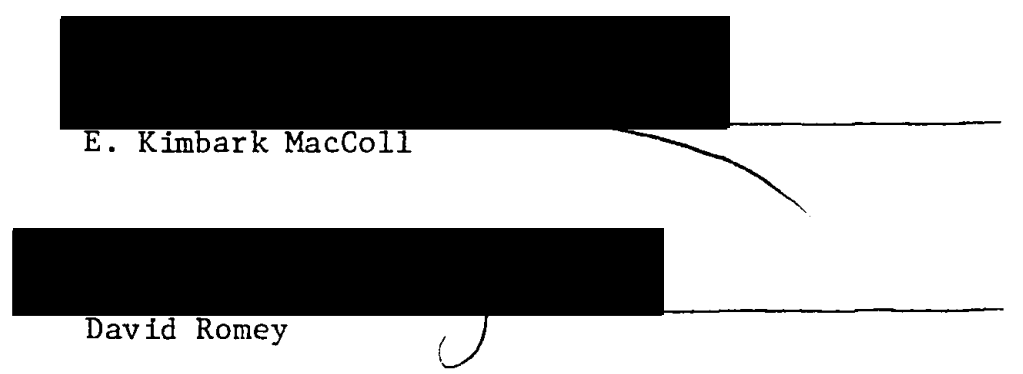

No other ethnic group enjoyed the level of success, defined in terms of economic status and social acceptance, attained by Portland Jews in the second half of the nineteenth century. Hailing predominantly from the German states of northern and central Europe, the Jewish pioneers transplanted middle class values and mercantile skills in their new home. From a small unstable population of single men in the 1850s, Portland Jewry grew into an affluent class conscious family orfented 
community by the mid-1880s.

The center of Portland's Jewish life during the formative years was Congregation Beth Israel, the first congregation in the Pacific Northwest. It provided the spiritual and social cement the community needed to meet the challenges of the frontier environment. As the population increased, the institutional structure of the community expanded with a succession of organizations--Hebrew Benevolent Association, Hebrew Ladies Benevolent Society, B'nai B'rith, YMHA, to name the most prominent.

As the population increased with the immigration of Polish and Prussian Jews in the 1870 s, some internal struggle occurred. The more traditional Jews, primarily from eastern Prussia, formed a new congregetion, rejecting the reforming, Americanized Beth Israel. In the 1880s the split became further institutionalized as the wealthy German Jews established the Concordia Club, a social club for the Jewish elite.

Despite this division, Portland Jewry remained fairly homogenous through the 1880s. The outstanding distinguishing characteristic of the community was its adaptation to American soctety and its integration into city life. The pioneer Jews sought the same rewards as their gentile neighbors--economic success and community stability. They experienced little racial prejudice and moved with no apparent self consciousness in Portland society. Although they were excluded from the Arlington Club, the bastion of the gentile elite, Portland's Jews maintained close business and social ties with the non-Jewish community. This experience was similar to that in other frontier communities where Jews entered city Iife early in its development.

While becoming Americanized, Portland Jewry clung to its cultural 
heritage. Its organizations and institutions which showed the effects of the frontier environment were still distinctively Jewish. And in business, success was fostered by intra-group and family networking and credit arrangements that were familiar in Europe The use of "new social history" techniques provides a view of all levels of Jewish society. By using data gathered from federal and county census records, burlal records, marriage records, and tax records, as well as institutional records and personal papers, the development of institutional structure, leadership roles, and class divisions can be understood. 


\section{ACKNOWL EDGEMENTS}

No historical work is ever the product solely of the author-and this thesis is no exception. The contributions to this history by instructors, friends, archivists and librarians were great, indeed, and my debts are large.

A mere statement of gratitude is insufficient in acknowiedging the contribution of my advisor and thesis director, Professor David A. Johnson. His probing inquiries during the formative stages of subject development facilitated an early and clear definition of its direction. His encouragement at every stage of thesis research and writing kept me going when the spirit waned. And his critical eye and stylistic suggestions were invaluable in the preparation of the final draft.

I want to thank the other nembers of my thesis committee who read the manuscript in its very rough first draft and offered constructive criticisms. My gratitude is extended to Professor Victor C. Dahl and E. Kimbark MacColl who stimulated my interest in regional and local history, and to Professor David Romey whose questions were provocative and challenging. A particular note of thanks goes to Dr. William Toll who early in the development of my topic provided insights and suggestions which helped shape this work. I am indebted to him for the opportunity to read prior to publication the first two chapters of his history of Portland Jewry.

Thanks is owed to the archivists and 1ibrarians of several research institutions, notably the Oregon Historical Society; Western Jewish 
History Center of the Judah L. Magnes Memorial Museum, Berkeley, California; Bancroft Library, University of California-Berkeley; American Jewish HJstorical Society, Wal tham, Massachusetts; Susalow Library, University of Washington; and Portland Archives and Records Center. The Board of Directors of the Jewish Historical Society of Oregon hired me to organize its archival records, providing an opportunity to pull together useful material in that collection, as well as financially supporting my graduate study.

No job seems more overwhelming than the final typing of a thesis. For her perserverance, good humor, and ability to decipher my writing and directions, I am deeply grateful to Athena Pogue-wail.

Finally, my deepest afpreciation goes to my toughest critic auu the inspiration for this work--my wife Carolyn Cohen. Her criticisms, suggestions, and editing made this a better work; and her encouragement and understanding eased the burden of returning to school after several years absence. It is Carolyn to whom this work is dedicated. 


\section{TABLE OF CONTENTS}

PAGE

ACKNOWLEDGEMENTS . . . . . . . . . . . . . . . . 1ii

LIST OF TABLES ..................... . . . . vi

INTRODUCTION ................... . vii vi

CHAPTER

I THE EARLY YEARS, $1849-1862$. . . . . . . . . 1

II PROFILE OF AN EXPANDING COMMUNITY . . . . . . . 19

III THE COMMUNAL IMPULSE . . . . . . . . . . . 38

IV OCCUPATION, PERSISTENCE AND ECONOMIC MOBIIITY . . . 62

V JEWS IN THE LIFE OF THE CITY . . . . . . . . . 79

VI AN EMERTING SENSE OF CLASS . . . . . . . . . 97

CONCLUSION ................................ 114

ENDNOTES .......................................... 121

BIBLIOGRAPHY . . . . . . . . . . . . . . . . 155 


\section{LIST OF TABLES}

I Birtinplace of Portland Jews 16 Years of Age and

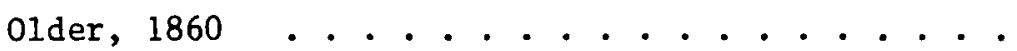

II Population of Portland and Portland Jewish Community, 1860-1880 ................. . . . .

III Origin of Foreign Born Jews by Sex, 1870-1880 . . . .

IV Foreign Born Jews as Percent of Total Foreign Born,

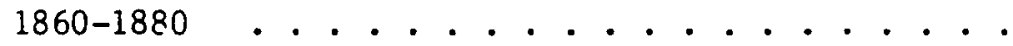

V Marital Status of Portland Jews 18 Years of Age and 0lder, 1860-1880 . . . . . . . . . . .

VI Population of Portland Jews by Age and Sex, 1860-1880 .................

ViI Place of Marriage or Birthplace of First Child,

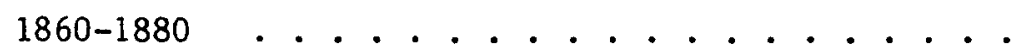

VIII Foreign Born Jews as Percent of Jewish Population by Age, $1860-1880$.............

IX Congregation Beth Israel Membersh1p by Origin, $1860-1880$. . . . . . . . . . .

X Persistence by Marital Status, $1860-1870$ and $1870-1880$. . . . . . . . . . . . .

XI Wealth in 1870 of Jews Persisting 1860-1870 .... .

XII Personal and Real Wealth of Persisters and Non-Persisters, $1870-1880$. . . . . . . . 
XIII Occupation of Persisters, $1860-1870$ and 1870-1880 . .

XIV Occupational Class of Portland Male Jews by Marital Status, 1860-1880 ............

XV Birthplace of Concordia Club Members Located in 1880 Census . . . . . . . . . . . 107 
INTRODUCTION

One student of Portland history noted that "Portland grew by means of the gradual accretion of individual entrepreneurs and by the ropid and often disorderly accumulations of speculators." ${ }^{\prime}$ A small, though disproportionately important, class of entrepreneurs who assisted in the growth of Portland were Jewish immigrants seeking an economic advantage on the frontier. Jews established a permanent community early in Portland's history and by the 1880 s had developed into an affluent, stable presence. The economic contours of the city satisfied the entrepreneurial designs of the aggressive, but conservative Jewish businessmen who concentrated in thc retail, wholesale, and importing trades.

This study analyzes how Portland Jewry, both its leaders and "ordinary" citizens, structured a community and contributed to the development of the city from 1850 to the mid-1880s. The following chapters probe the motivations and aspirations of the community's founders over forty short years in which they constructed the basic institutional framework that would serve as the organizational model for future generations.

The mid-nineteenth century was a critical period in the life of American Jewry. European immigration continually enhanced the Jewish population and the westward impulse spread Jews across the breadth of the United States and its Territories. Jewish pioneers appeared in Portland almost at the point of the city's founding--a circumstance which served 
to aid their integration and acceptence into the frontier community.

The Jewish experience in the West, as In America generally, was decidedly urban. As early as 1861, nearly half of Oregon's Jews lived in Portland, ${ }^{2}$ with most of the balance found in growing towns such as Salem, Corvallis, Albany, and Jacksonville. Therefore, this work also addresses the Issue of urban development and how one distinct group contributed to the birth and growth of the western city.

In recent years American Jewish historiography has undergone a revision which has resulted in new perceptions of the social, political, economic, and cultural experience of Jews in the United States. The long dominant view, articulated by Jacob Rader Marcus, assumed that sequential waves of ethnic immigration determined the main contours of American Jewish history. This hypothesis, reduced to the simplest form, describes three distinct periods of Jewish immigration: the Sephardic, 1654-1776; the German, 1820-1880; and the Eastern European, 1880-1924. However, in his review of American Jewish historiography, Oscar Handlin has argued that all too often this tripartite scheme was used to explain the commural development of American Jews, assuming, for example, that a German-East European split alone explained community divisions. Handlin contends that these tripartite divisions are artificial--that during the colontal period Polish and German Jews emigrated as did Russian and Polish Jews during the German era. He argues, in short, that the "traditional divisions of the Jewish past in the United States rested on a false premise." 4

Handlin believes that too much American Jewish historical writing looks inward for the effect of subsequent waves of immigrants on the preceding group. That consideration, important in its own right, 
Ignores and obscures the place of the Jews in the broader American culture and the effect of the American environment on Jewish communities and institutions. Handlin argues that the problems faced by Jewish immigrants were steps in the acculturation of their institutions, religion, and cultural identity. ${ }^{5}$ William Toll, a student of Portland Jewry, seems to agree when he concludes that American Jewish distinctiveness from other Jewish communities is not based on the development of peculiarly American forms of Judaism, but on the same social tensions which affected other American imigrants. 6

Ellis Rivkin argues that the fate of Jews everywhere was bound to the changes in the host soclety's economy. He sees the cause of Jewish immigration as "the break-up of a European pre-capitalist society resulting from the penetration of capitalism." As the relationship of Jews to the pre-capitalist agricultural system was broken, Jews were propelled to America. Rivkin argues that because capitalism had not reached equilibrium in America, opportunity was rife for the Jews. During periods of economic disintegration, Jews faced a hostile environment, but in a society where capitalism was growing and developing, they could find a friendly home. Rivikin argues that "emancipation and a tendency toward equality always went hand in hand with new outbursts of capitalist energy." 7

Acquiring equal rights and gaining acceptance in America was never a difficult stiuggle, according to Lloyd Gartner, a student of urban Jewry. He sees a jewish community that feels at home in its own country: "In these repects we see in America an emancipated Jewish society probably wthout parallel." Gartner belleves the substance of American Jewish history is the investigation of true freedom and the 
question of how Juda1sm was redefined in America. 8

The methodology employed in the "New Social History" has broadened the scope of Jewish historlography. Quantitative methods have opened the door for historians who wished to recreate the lives of ordinary people rather than emphasize only the roles of religion, welfare institutions, and elites in community development. ${ }^{9}$ Broad urban historles of this genre have been written on the Jews of Atlanta and Columbus, Ohio. ${ }^{10}$ More specialized historles, keying on specific issues or limited time periods, have been written on New York, Syracuse, Las Angeles, San Francisco, Denver, and Portland. ${ }^{11}$

William Toll noted that the use of federal and 1ocal public records provides the historian with a key to the issues of housing, employment, family organization, education, fraternity, residential and geographic mobilty, and the development of class structure. He argues that historians need to emphasize class development and structure to see how classes relate, fade, or grow. ${ }^{12}$ Quantitative analysis also provides an opportunity to compare a single ethnic group's experience in several locals or to contrast different groups in a single area. Toll calls for exactly these kind of studies to further our understanding of the social and economic mobility of different groups. ${ }^{13}$ And Steven Hertzberg presents many of his findings about Atlanta Jewry in quantitative terms so that they "will permit comparison with those of future studies." 14

All these views have influenced this study. Each has merit and I have accepted none as the last word in the writing of American Jewish history. Thomas Kessner could have been discussing American Jewish historlography when he wrote about mobility studies--that they "are still very much like the proverbial blind men touching different parts 
of the elephant: no single description is inaccurate but all are incomplete."15 This Investigation into the development of the Jewish community structure in Portland Includes use of the traditional source material for such historles: congregational records, organizational records, personal papers, and newspaper accounts. Additionally, information was taken from the United States Census, cemetery records, and early county tax and census records found in the Oregon Territorial Documents.

The following chapters are primarily topical in nature, although their structure and arrangement fall roughly in a chronological order. Chapter One deals with the first decade of Jewish settlement in Portland and the first tentative steps in communal development. Chapter Two presents a profile of the people through statistical analysis. Chapter Three concentrates on the evolution of Jewish organizations. Chapter Four raises the issue of economic and occupational mobility and the business structure of the community. Chapter Five treats the role Jews played in the civic, cultural, and political life of the city. Chapter Six closes the perlod with a look at the emergence of a class consciousness within the Jewish community.

Historla: Abraham I. Karp, uriting about the American German-Jewish community in the 1850s, noted it was "beginning to establish those institutions and organizations which would give it structure and identity, which would answer the needs of today, and lay the foundation for the community of tomorrow." 16 As Portland began to emerge in the 1850 s as the leading urban center of the northwest, the Jews who chose to settle in the city were entering the stage of development Karp described. By the mid-1880s Portland Jewry had matured and created the institutional 
framework upon which future generations would build. 
THE EARLY YEARS, $1849-1862$

Like most of the cities and towns of the west coast in the 1850 s, the initial growth experienced by Fortland resulted from the 1849 California gold rush. On the eve of the gold rush, Portland was 1ittle more than a stump-1ined village with a few hundred residents. Nine years earlier Massachusetts ship captain John H. Couch discovered a deep water anchorage adjacent to a level, forested site twelve miles upstream from the Willamette River's confluence with the Columbia. Recognizing the commercial potential of the site on the river's west bank, Couch moved his merchandise store from Oragon City to a clearing which later became known as Couch's Addition. Other proprietors, also appreciating the geographic advantage of Couch's discovery, began developing the location, forsaking the then larger oregon City which was situated above Willamette Falls, a barrier tc sailing vessels. In 1845 the young settlement was named Portland and a townsite of sixteen blocks was platted. Settlers cleared the forest to make way for streets and used the lumber to construct homes and small shops, creating by 1848 what one observer descrthed as a "small and beautiful village of about 100 (with) an air of neatness, thrift, and industry." 1

During the four decades following the platting of the Portland townsite, the village grew steadily, becoming the predominant coumeicial center of the Pacific Northwest. River transportation, shipping, 
and merchandising produced the economic leadership of the city from 1850 into the mid-1880s. ${ }^{2}$

However, the early settlers faced uneasy times in the fragile economy of the mid-1840s. Despite the proximity to the agricultural settlements on Tualatin Plains, markets for Portland merchants were 1 imited and shipping was both difficult and costly. In 1847, a large immigration to Oregon and the beginning of a small California market produced a measure of stability in Portland's economy. ${ }^{3}$ But gold was the impetus for growth in commerce and population. Although the discovery of gold in California nearly depopulated Portland for a short time as members of the community, dreaming of instant wealth, packed their grips and headed for the mines, the ultimate effect of the gold rush was expansion of trading markets for local merchants and a lucrative business in supplying provisions for the mining camps.

The gold rush populated Calffornia almost overnight as tens of thousands of adventurers from every corner of the United States and from several foreign nations sailed around the horn of South America or packed overland to try their luck in the mining regions. Among this migration was an indeterminate number of young Jews. The Jews of midnineteenth century America had already played a role in the westward movement, entering the frontier one step behind other settlers. Seldom in the vanguard of explorers and pioneers, Jewish peddlers and traders followed the lines of settlement with an eye toward exploiting expanding comercial markets. Of the Jews who migrated to California during the gold rush, it is likely that only a handful attempted prospecting since it was not an occupation known in central and northern Europe where most of them were born. Yet, Jews became an intergral part of the mining 
economy, peddli:?g goods, supplying gold camps by pack-train, or establishing small retail stores in San Francisco and the mining communities of the Sierra Nevadua. 5

Life in the mines and mining communities was hard and success was elusive. Many forty-niners whose dreams of fortunes were shattered by the realities of prospecting left California to begin anew, to search out more lucrative opportunities. Among them were Jews who like their gentile fellow pioneers placed the quest for economic success foremost in their thoughts. "To these men," historian Robert E. Levinson observed, "if the chance of greater profits existed in a new region or community, the distance to be travelled in order to cash in was immaterial." 6 Market potential was the most significant factor affecting mid-nineteenth century Jewish migration in America. ${ }^{7}$ It was that consideration that accounted for the appearance of Jewish settlers in Portland in 1849. The lure to Portland was strong for the more adventurous pioneers who were leaving the gold camps. The region was sparsely populated and relatively undeveloped. But, more important, with its location on the Willamette-Columbia Rivers system, the young town offered a bright commercial future for those who were willing to invest their energy and sweat.

Jews entered the Oregon Territory as early as 1840 and it is not unwarranted to assume that a Jewish peddler may have sold his wares in or around Portland prior to 1849. However, students of Portland's pioneer Jews agree that Jacob Goldsmith and Lewis May were the town's first Jewish residents. 8

Little is known about Goldsmith and May. They operated a general merchandise store on Front Street for two years before leaving Portland. 
Both men joined a group of local merchants in forming the city's first Masontc lodge in 1850. May served as the first Grand Marshall of the Grand Lodge of Oregon and Goldsmith was the Portland lodge's representative to the district lodge in California when the former applied for its charter.

Born in Worms, a free city bordering the German state of Hesse, May immigrated to the United States in 1840, settling in Shreveport, Louisiana, where he entered upon his Masonic career. Whether May moved from the south to California before he migrated to Portland is unclear. Goldsmith, on the other hand, came to Portland from San Francisco where he apparently was a partner in J. Goldsmith and Company, an auctioneering firm. Goldsmith returned to San Francisco in 1851 and in the same year May left fnr New York where he became involved in banking and railroading. 9

Following on the heels of Goldsmith and May were several young Jews--often brothers or cousins travelling together--who made their way to Portland and eventually hecame influential community leaders. Simon Blumauer, a merchant from Bavaria, operated a retail store with his brother Jacob as early as 1851 and served as President of Congregation Beth Israel for nearly two decades. 10 The majority of Jewish immigrants, however, either stayed only a short time or immediately fanned out into the surrounding environs.

The first decade of Jerish immigration to Portland was characterized by a high degree of mobility which is illustrated by the population statistics drawn from early census records. The 1850 United States Census for Portland counted only one person in Portland who can be identified as Jewish. That individual, Isaac Stamper, a 32 year old 
Prussian-born merchant, did not appear in the Washington County Tax Roll of 1852 , the county census of 1853, nor in the United States Census of 1860 . Of the 3808 people in Washington County in 1853, only nineteen Jews can be Identified, all of whom resided in Portland. Fifteen of them ( 79 percent) were adult males, and all but one were single. By 1860 only five remained in Portland. 11

of the fifteen Jewish settlers who did not remain through the decade, only two, brothers J. B. and Maier Hirsch, can positively be traced beyond Portland. The Hirschs arrived in Portland from the southern German state of Wurtemberg in 1852 and by early 1854 had moved to Salem, Oregon, where they established a general store. They were joined in Salem during the 1850s by their brothers Leopold, Edward, and Solomon. The former was a partner with Jacob and Simon Blumauer in Portland in 1851, apparently operating a branch of the firm in Salem until the 1860s. Solomon, following a decade and a half of merchandising in Salem, Silverton, and The Dalles, settled in Portland and in 1875 became a senior partner in Fleischner, Mayer and Company, the largest wholesale merchandise house in the northwest. Edward and Solomon played leading roles in the state's Repuolican party in the 1ate 1870 s and $1880 \mathrm{~s} .{ }^{12}$

The early departure of two-thirds of the Jews 1isted in the 1853 census can be explained only in part by the experience of the Hirsch brothers who found Salem a more attractive market. It is likely that a certain number of the Jews in 1853 felt the effects of the fragile economy of the region. Although the Calffornia gold rush had produced a surge in the Portland economy allowing local merchants and shippers to exploit gold-created markets as well as the small expanding regional markets, by late 1853 an overabundance of eastern goods shipped to the 
mercantile outlets of San Francisco hit Portland like a thunderbolt. The city sank into a depression that lasted for two years. ${ }^{13}$ With money tight, prices low, and no distant market to supply, merchandisers faced economic hardships. Thus it is highly probable that most of the Jews who did not remain in Portland left as a result of the downward spiral of the economy. Like other Jews of the period, they recouped their losses and sought success elsewhere. ${ }^{14}$

Despite a dependence on San Francisco, the Portland business community rebounded from the 1853 depression and the city continued to grow in population and commercial strength. Gold discoveries in eastern Oregon and Canada, expanded ocean shipping, and the development of local river transportation assured success for Portland merchants. ${ }^{15}$ While the Jewish community barely expanded to an estimated population of twenty-five by 1855, it grew flve-fold by 1860 with the influx of Jews who left the mining regions of California to seek a less risky environment. While the vast majority moved to San Francisco, large numbers of Jews migrated to Phoenix, Salt Lake City, Los Angeles, Sacramento, Stockton, and Portland. 16

The Jews who immigrated to Portland in the 1850 s were almost exclusively German born or of German parentage. Foreign-born accounted for fifty-seven percent of the Jewish population of the city in 1860 with eighty-eight percent of the persons 16 years of age or older hailing from Europe. Sixty-eight of the seventy-four foreign-born adult Jews ${ }^{17}$ In the 1860 census imigrated from Germany Including sixty-two percent of those from the southern German states, principally from Bavaria (Table I).

There is no indication that any of the Jevish immigrants in the 
1850s arrived in Portland directly from Germany. For them, Portland was a secund ot third or ever fourth stop. Jacob Mayer, a co-founder of Flelschner, Mayer and Company, and a religious and fraternal leader in the community, came to the United States in 1842 from Bechtheim in the German state of Hesse and resided in three cities prior to his arrival in Portland in 1857. He clerked for a brother in New York from 1842 to 1847, then took up residence in New Orleans until the gold fever led him to San Francisco in 1850. Aaron Meier, founder of the Meier and Frank department store empire, made only one stop on his way to Portland. He worked as a clerk for his brothers Julius and Emmanuel in their Downleville, California general store before settling in Portland in 1857. ${ }^{18}$

TABLE I

BIRTHPLACE OF PORTLAND JEWS

16 YEARS OF AGE AND OLDER

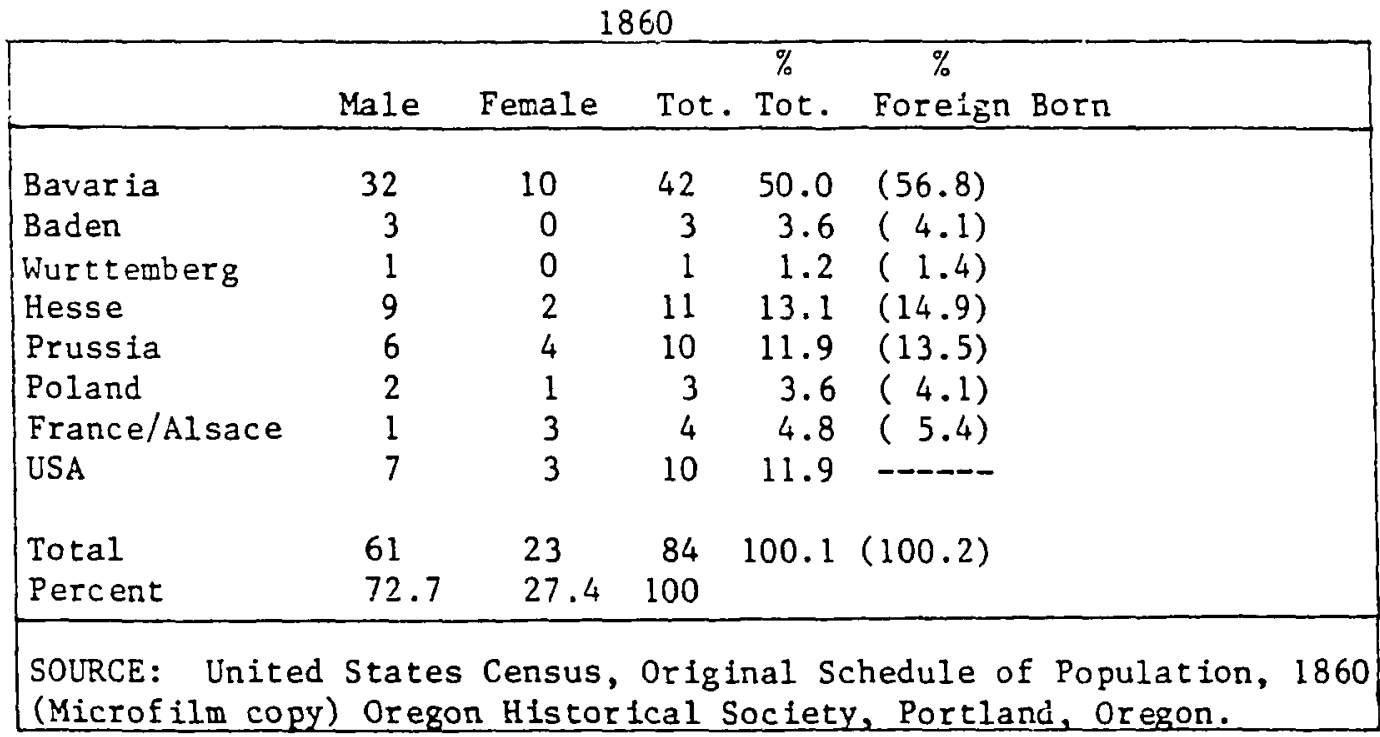

Not all of Portland's pioneer Jews came to the city by way of California. By using the biographies in Joseph Gaston's history of Portland and tracing the birthplaces of children listed in the 1860 census it is possible to determine the routes travelled by 21 adult male Jews 
who arrived in Portland in the 1850s. Eleven of them lived in California prior to migrating to Portland. The others arrived in Portland after first testing the markets of the midwest or south. 19

The migration pattern of Jews who settled in Portland clearly indicates that they had experience with the American frontier before arrival in Portland. By the time they reached the town, they could speak rudimentary English and had adapted in part to the frontier lifestyle. While they may have spcken German among themselves, none of the organizations they founded in the community's first three decades used other than English in conducting meetings or keeping records. 20

The use of English, rather than their native German language, was part of the Americanization process that most pioneer Jews embraced. Although they were proud of their German heritage and strove to retain certain elements of their Germanness, the ploneer Jews were also concerned with adapting to and being accepted by the host society. ${ }^{21}$ Because so many of the western pioneers in the 1850 s were immigrants the issue of acceptance might not, at first glance, seem so immediate. Indeed, as Paul Merriam has observed, "Portland, like other cities of the Far West, was in the broadest sense a city of tmmigrants and their offspring," 22 While it is true that over one-quarter of the city population was foreign-born in 1860, more than half of that group immigrated from English speaking countries. Additionally, the community leaders and the institutions they built were decidedly Anglo-American. Therefore, learning and speaking English must be viewed as a means for the German Jews to integrate with the rest of the populace.

The Jews who came to Portland during the first half of the 1850 s were involved almost exclusively in general merchandising as 
storekeepers and, in a few instances, peddlers. Over the course of the decade, Jewish firms began to specialize and skilled laborers began to settle in Portland. Joseph and Isaac Bergman established a butcher shop on First Street in 1856. In 1859 Moses Seller moved from Corvallis, where he had operated a dry goods store since 1852, and opened a crockery store. But the majority of Jews who found their way to Portland during the decade continued to deal in general merchandise and dry goods. 23

The 1860 census listed 146 merchants in the city and almost onethird were Jews. ${ }^{24}$ Gentiles such as wililiam S. Ladd, Henry W. Corbett, Stephan Coffin, Asa Harker, and Cicero H. Lewis had already accumulated over $\$ 40,000$ in real and personal property, but only one Jewish merchant, Abram Weil, exceeded $\$ 20,000$ in 1 isted wealtin, and even that figure is deceptive. In partnership with his brother Moses, Abram Weil operated a dry goods store. The 24 year old Moses Weil, three years younger than Abram, listed no property. It is reasonable to assume that in the Weil's partnership, the older sibling managed the finances. A simflar, but more striking example, is A. B. Elfelt who with three brothers operated Elfelt and Company, a retail dry goods firm. A. B. Elfelt claimed property values at $\$ 15,000$, while none of the brothers listed any property. 25

The 1850s was a period in which the foundations of many Portland fortunes were laid. Although none of the Jews listed in the 1860 census had acquired a large amount of property, many were becomong quite comfortable. Despite a continuing high incidence of out-migration from Portland, ${ }^{26}$ undeniable signs of permanence among the Jewish community were visible as early as 1853 when Jacob and Simon Blumauer erected the 
city's second brick building. By the end of the decade, of thirtythree brick structures interspersed among the frame buildings, seven had been constructed by Jewish merchants. 27 The brick buildings, sturdier than their wooden counterparts, stood as signs of a permanent Jewish presence in an expanding city.

Coinciding with the commitment to remain in Portland and coupled with a growing population in the latter half of the 1850 s was recognition of the need for organizing basic Jewish communal services. Frontier life imposed the dreaded possibilities of death from disease and high infant mortality, so that the need for traditional Jewish burial preyed heavily on Portland Jews at mid-decade. Julius Nodel, in a history of Portland's first Jewish congregation, argued that the birth of a son to Simon and Mollie Blumauer in 1855 created an urgent need for a religious institution. ${ }^{28}$ And in virtually all burgeoning Jewish communities of the mid-nineteenth century, the burial society and synagogue were founded as the initial response to communal needs. ${ }^{29}$ Creation of those two organizations did, indeed, grow out of a deeply felt communal need. But reaching consensus about these matters was no easy task in the small and unstable community.

The concern for traditional Jewish burial is a thread that is found throughout the history of American Jewish communities. In Europe, burial was handled by the kahal, a form of "corporate" structure that dominated the communal life of the Jews in a city, town, or village. The kahal was a semi-autonomous, quasi-governmental entity given jurisdiction over the Jewish community by the local prince, baron, or king. The leaders of the kahal generally included the religious and business leaders of the Jewish community. The kahal levied taxes and in turn provided all 
the services its constituents expected. 30 Attempts to institute the kahal in America failed, primarily because of the democratic nature of the institutions in the young country. During the colonial period, Sephardic synagogues operated as nearly like a kahal as possible. They controlled the institutional and communal life of colonial Jews. Charity, Jewish education, and burial all fell under the synagogue jurisdiction. The German Jews who arrived in the nineteenth century did not accept the autocratic nature of the Sephardic synagogue and began creating their own religious institutions. The burial ground often preceded the synagogue in the German Jewish immigrant experience, although in Portland, as elsewhere, the synagogue eventually assumed control of the cemetery. In some cases the cemetery was owned and operated by a benevolent sosiety or a fraternal order. 31

In his study of American Judaism soclologist Nathan Glazer noted that "almost all Jews wished to be buried in hallowed ground."32 In Portland, however, there seemed to be some opposition to formation of a burial society. When the issue arose is conjecture. In 1855 Portlander Moses Abrams wrote Isaac Leeser, the leader of traditional Judaism in America, concerning his desire for a cemetery. "We are trying to get a Jewish burying ground," Abram wrote. "There are sum [sic] here who want to wait a while. We are all healthy persons, but I think it is better to prepare." 33

The reasons for the oppostition and who the opponents were are unknown. One possible explanation is that establishing a burial soclety required the purchase of land and membership dues. Portland Jews may have felt their financlal position was less secure than they would prefer before expending sums on a burial ground. A more probable 
explanation related to the high geographic mobility of Portland's first Jewish settlers. Portland often was not the first or final stop in their search for economic success. And thus, without plans to remain in the city, they shied away from supporting a burial ground that would be of no use to thein. In light of the low (33 percent) persistence rate from 1853 to 1860 , this explanation is quite plausible. However, at some point between Abrams' letter of July 10, 1855 and the first recorded meeting to consider forming a congregation on May 2, 1858, the Mount Sinai Cemerery Association was founded.

Twelve men met at the National Hotel in May 9, 1858, and elected officers for the first congregation in the Pacific Northwest. At a meeting a month later the Constitution and By-laws of San Francisco's Congregation Emanu-E1 were temporarily adopted until the new congregation had written its own. "Thus, regularly organized, with nineteen members, did Congregation Beth Israel engage in the holy mission of preserving the rites and customs of the ancient faith of their fathers, and transmitting in purity its elevating principles to the rising generations." 34 Considering the size of Portland's Jewish population in the mid1850 s, organization of a religious institution came late. Cities like Cleveland and Cincinnati had congregations almost as soon as there were enough Jews to form a minyan--a quoram of ten males over the age of thirteen required to hold services. The explosion in San Francisco's Jewish population following the discovery of gold resulted in the formation of two congregations as early as $1850 .^{35}$ Enough adult male Jews lived in Portland by 1853 to form a congregation, and by 1860 sixty Jewish maies over the age of fifteen lived in the city. It is unlikely that the qualified male population dropped below ten between 1853 and 
1858. Why, then, did it take five years for a congregation to develop? The announcement in The Weekly Gleaner of San Francisco of Beth Israel's organization noted: "Much opposition was manifested against this laudable movement by those who little care to exhibit the true principles and beauties of our religion." 36 No records of that organizational meeting remain, and neither the extent nor source of the opposition can be definitely known. However, a possible clue is found in the Articles of Incorporation, filed with the Territorial Government in January, 1859, which stated that Beth Israel was created "for the purpose of conducting religious worship, in conformity to the Minhag Ashkenass, or Custom of the German Israelites...." 37 If discussion at the meeting turned toward which ritual or prayer book to adopt, then a spirited opposition can be explained. The German Minhag was followed throughout the German states with subtle changes in each locale. Jews who immigrated from Poland or the former Polish province of Posen (part of Prussia after 1793) generally followed the Minhag Polen, a slightly more traditional custom. Though the difference was more in nuance that substance, a division existed between the adherents which seldom was bridged. By the 1850 s most large Jewish communities expressed this split either by establishing two separate congregations simultaneously (as in San Francisco), or by suffering a schism within a single congregation. 38

Few Polish or Posener Jews lived in Portland in 1858, but those who did may have opposed the creation of a congregation along the lines of German custom. No Poles appear among the members in 1861 nor among the officers in the years pervious, and the founders were almost exclusively from Bavaria, the Hessen provinces and Prussia. ${ }^{39}$ Thus, it 
appears 1ikely that the Pollsh Jews did initially reject Beth Israel. But since ninety percent of the adult minle Jews in 1860 halled from German states, 40 opposition to a congregation cannot be laid entirely on the more traditionally minded.

Ten of the twelve men who met to establish Beth Israel are found In the 1860 census. By studying the ages of their children it can be determined that at least nine of the ten were married, most with young families, at the time of the congregation's creation. Elghty percent of the members in 1861 who can be located in the 1860 or 1870 census were married by that year. Thus, a correlation can be drawn in Portland between the stage in the life cycle and establishment of a IEIigious institution. Although one Jewish family could be found in Portland as early as 1853, and although the Blumauers began another family in 1856 , it was not until 1858 that enough families resided in the city to warrant a congregation. Nodel's suggestion that Louis Blumauer's birth created an urgent need for organization should, therefore, be viewed symbolically as a commitment to remain in Portland rather than literally as an immediate necessity for commity structure.

Most of the Jews in Portland during the 1850 s were single men trying to establish an economic foothold. They hoped for enough success that they could then marry and begin a family. ${ }^{41}$ Simon Blumauer attained a comfortable position by 1853 . In that year he travelled to New York and married Mollie Radelsheimer. They returned to Oregon and soon eatablished a familȳ. Aaron Mefer, who came to Portland in 1857, travelled to his home in Hesse-Darmstadt in 1864 and married a cousin, Jeanette H1rsch. ${ }^{42}$ Only after his marrlage did Meier join Beth Israel. The pattern of working to build economic stability and only then marrying 
and joining a congregation repeated throughout the nineteenth century among German Jews. In the 1850 s and early 1860 s, most men sought wives in New York, San Franctsco, or even Germany, as in Meier's case.

Portland Jews were unusual in their desire to marry before establishing a congregation. It certainly explains the failure to organize between 1853 and 1858. But that was not the common experience of midnineteenth century Jewish communities. The cities of Cincinnati, Cleveland, and San Francisco all saw congregations created with large numbers of single men. Perhaps there was a feeling during mid-decade, in the midst of an unstable economic climate, that Portland might not offer the optimum environment for establishing a comnunal structure. Given the uncertainiy of life in a frontier society, young single Jewish men had no overriding commitment to remain in the city. Only after the more successful pioneer Jews decided to stake themselves and start families did the urge for community begin in earnest.

Once established, the synagogue's attraction was strong because it provided a spiritual haven in a frontier community which was still characterized by its roughness. Portland at the dawn of the 1860 s remained a small town of 2,874 , economically dependent in great measure on California markets. 43 The need for cohesion and stability, and support and companionship was not lost on Portland Jews. Only one-third of the males 16 and over in the 1860 census were members of Beth Israel in 1861. During the following decade, another one-third of the 1860 male population joined. Most of the latter group were single in 1861 , but married in subsequent years and then joined the congregation. Only three of the elghteen married men in 1860 failed to join Beth Israel. Two of those, Louis Rosenthal and M. Jaretsky, were Polish. The third, 
P. Frankenstein, a Prussian merchant, did not renain in Portland. of the 17 adult males who remained in Portland through the Jecade, only two failed to become members of Beth Israel--Louis Rosenthal, again, and Bavarian tobacconist Henry Rosenfeld. Rosenfeld's brother and partner Issac did affillate with Beth Israel.

Soon after its creation, the congregation became an agent for stability in the small community. Julius Nodel has claimed that charity and economic assistance were dispensed from the beginning. He reported that venture capital, as well as aid to the sick and bereft, were available to members and non-members. ${ }^{44}$ No synagogue records exist prior to 1865 to confirm Nodel's contention. The records after that date illustrate synagogue charity regarding burials ${ }^{45}$ but nothing about aid to the sick. Nevertheless, there is reason to believe that benevolence from the congregation was part of its early function since charity traditionally was the purview of the synagogue in the kahal structure of Europe, as well as in mid-nineteenth century Jewish communities in America. ${ }^{46}$

In the Spring of 1859 , Portland Jews took their first step toward an organized system of benevolence that had no attachment to the religious institution. The First Hebrew Benevolent Association was founded by members and non-members of Beth Israel. Jacob Mayer, in keeping with his organizational propensities, was a founder of the benevolent society. He also was instrumental in the organization of Beth Israel and the first B'nai B'rith lodge in Portland. Additionally, he assisted in the creation of the second benevolent society in San Francisco and that city's first B'nai B'rith chapter. ${ }^{47}$ The officers in 1859 included three young merchants and a jeweler. Two of them, Leopold Mayer 
(Jacob's brother) and J. Kalmes, were also founders of Beth Israel. ${ }^{48}$ No evidence survives to show the size of the membership. The policy and means for providing charity in 1859 is unknown. However, it probably did not change perceptibly by the time the society incorporated in 1863, when the Articles of Incorporation stated that "Its purposes and occupation shall be acts of Fellowship and Charity namely to relieve the distressed and support the afflicted attend the sick and bury the dead. $" 49$

The necessity for a benevolent society in Portland in 1859 is unclear if Beth Israel was administering charity. It is likely that the financial demands of the operation of the congregation limited its ability to dispense aid. Moreover, a synagogue was erected in 1862 and the membership coffers felt the pinch of construction and maintenance costs. 50 The number of Jews arriving in Portland was rapidly increasing. The need for charity, or initial assistance, grew as the population grew. Additionally, in 1862 Beth Israel, by mutual agreement, was given title to the Mt. Sinai Burial Association property and assumed responstbility for the proper burial of the deceased. 51

As Portland's Jewish community moved into the 1860s, it exhibited the rudimentary elements of communal 11fe. The spiritual and associational needs of an ethnic group settled in the midst of an open, raw land had been addressed by establishment of Congregation Beth Israel. Concern about frontier hardship and the vagaries of old age were met by the purchase of land and creation of a burial socfety. Finally, in recognition of the new immigrant's needs, an aid society was created. In the two and a half decades to come, Portland Jewry would undergo an evolution that would radically alter the face of the fledgling community. 
Economic stability in the 1860 s, religious ferment in the 1870 s, and social stratification by the mid-1880s awaited. The demands of internal growth, and the force of external pressures would shape the contours and chart the development of an active and thriving Jewish community. 


\section{CHAPTER II}

PROFILE OF AN EXPAÑDING COMMTUNITY

When, in January, 1862, Congregation Beth Israel purchased a large tract of Carruthers Addition on the southern edge of Portland for the Jewish cemetery, the Daily Oregonian commented that

it was a subject of some remark that the larger portion of the property was purchased by our Jewish brethern. It looks as if the day is nigh at hand when the children of Judah and Benjamin will cease going to and fro, and become attached to the soil.1

The writer's observation contained an important insight about the Portland Jewish community in the early 1860s. The itinerant nature of the Jewish fresence in the 1850 s had been altered slightly by the creation of ethnic organizations, and that change was given further voice with the purchase of property in the name of the community. Although Portland Jewry had expressed its intention to create a permanent presence in the late 1850s, the gentile community, if the Oregonian article can be used as an indication, viewed the acquisition of 1 and in 1862 as a temporal landmark in Portland Jewry's evolution.

The commitment to build a Jewish commity in Portland ushered in a new stage in the group development. The 1860 s and 1870 s witnessed a substantial growth and maturation of the community. This was a period of transition, characterized by a sir-fold increase in population, institutional expansion and internal conflict over religious reform. BeEween 1860 and 1880 Portland Jewry changed from a small community 
composed primarily of young single male adults from the southern German states to a larger, well established community of families with a closer sex ratio, a greater percentage of married men, a broader age range, and a slight, though distinct, shift in national origin. The profile of the community was affected by the changes as they occured during the two decades and the direction of social and institutional development was an outgrowth of Jewish reaction to these changes.

Over the course of the 1860 s, Portland's Jewish population grew from 135 to 469 . In the following decade the population again increased, if less dramatically, to 768. Over the two decades Portland's Jewish population grew at about the same rate as the general population, but in a different pattern. Jews accounted for 4.7 percent of the city's population in 1860. Over the next decade they increased 245.9 percent while the city as a whole grew by 188.6 percent. In the 1870s, the growth rate of the Jewish population slowed to 67.4 percent while the city's population doubled. ${ }^{2}$ (Table II)

TABLE II

POPULATION OF PORTLAND AND PORTLAND JEWISH COMMUNITY $1860-1880$

\begin{tabular}{|c|c|c|c|c|c|}
\hline & $\begin{array}{l}\text { City } \\
\text { Pop. }\end{array}$ & $\begin{array}{l}\text { Growth } \\
\text { Rate }\end{array}$ & $\begin{array}{l}\text { Jewish } \\
\text { Pop. }\end{array}$ & $\begin{array}{l}\text { Growth } \\
\text { Rate } \\
\end{array}$ & $\begin{array}{l}\text { Jews as } \\
\% \text { of } \\
\text { Pop. }\end{array}$ \\
\hline $\begin{array}{l}1860 \\
1870 \\
1880\end{array}$ & $\begin{array}{r}2874 \\
8293 \\
17577\end{array}$ & $\begin{array}{l}--188.6 \\
111.9\end{array}$ & $\begin{array}{l}135 \\
467 \\
768\end{array}$ & $\begin{array}{r}----- \\
245.9 \\
67.4\end{array}$ & $\begin{array}{l}4.7 \\
5.6 \\
4.4\end{array}$ \\
\hline \multicolumn{6}{|c|}{$\begin{array}{l}\text { SOURCE: United States Census Bureau, Original Schedule of Population, } \\
1860 \text {, 1870, } 1880 \text { (Microfilm copies) Oregon Historical Society, Portland } \\
\text { oregon; Paul G. Merriam, "The 'Other Portland': A Statistical Note on } \\
\text { Foreign Born, 1860-1910," Oregon Historical Quarterly, 80 (Fall, 1979) } \\
\text { pp. 258-68. }\end{array}$} \\
\hline
\end{tabular}


The city's economic climate explains much of the difference in the Jewish and gentile growth patterns during the 1860s and 1870s. Portland's population reflected national and regional events such as gold discoveries and labor demands created by railroad construction. 3 Even during the depression of the 1870 s laborers were in demand. However, fan Portland Jews belonged to the urban labor class. Rather, Jews were almost exclusively white collar workers, artisans, or (to a lesser extent) semi-skilled workers. The fluid and expanding economy of Portland in the Sixties, and the increasing size of the city, provided an opportunity for the expansion of Jewish business establishments. The 1870 s, however, offered less opportunity for commercial development. The nation-wide Panic of 1873 and subsequent depression brought about by the failure of Jay Cooke--and locally the bankruptcy of Ben Holladay-hurt the small frontier shopkeeper who could not compete with larger, better established houses that could draw on larger capital reserves. ${ }^{4}$ For example, B. Hamburger, a 53 year old dry goods dealer who had operated stores in San Francisco and Sacramento, opened a store in Portland in 1871. He developed a small stock purportedly worth $\$ 8000$ but was unable to compete and was forced to petition for bankruptcy in 1873 . Likewise, N. Goodman, a dry goods merchant who originally came to Portland to operate a branch of Galland, Goodmarı and Company--a dry goods concern which failed in 1869--and later opened his own store, could not meet his notes in 1873 and was forced to declare bankruptcy and settle with his creditors. 5

Larger firms also experienced difficulty but were able to remain solvent. L. Goldsmith and Company, the successor to Elfelt and Company, was backed by almost half a million dollars in capital in 1873 . The 
wholesale dry goods firm had branches in New York and San Francisco. Bernard Goldsmith, capitalist, speculator, and mayor of Portland, purchased the firm in the 1860 s from the Elfelt brothers for his brothers Louis and Max, and he later became the principle partner. R. G. Dun and Company, the New York credit agency, reported in June 1873 that L. Goldsmith and Company "held that trade has been light and losses heavy all around." But by March, 1874 the Dun investigators reported that L. Goldsmith and Company experienced no unusual losses and that trade during the previous Fall was good. 6

Disastrous fires In 1872 and 1873 fanned the depressed atmosphere in Portland's business community. The August 1873 fire destroyed twenty-two city blocks and caused between $\$ 1.3$ and $\$ 2.3$ million in property losses in the city's commercial district. Jewish businessmen, like their non-Jewish counterparts, suffered large losses. Aaron Meier and Sigmund Frank lost most of their stock, but were abie to rebuild after a favorable settlement with their creditors. ${ }^{7}$ Henry Sinsheimer, a dealer in musical instruments whose business was modest, at best, was able to recoup his losses after the 1873 fire, but never managed more than a marginal operation afterward, 8

In addition to national and local economic trends affecting Portland in the 1860 s and 1870 s, the growth of the clty's Jewish population must be seen in the context of the general European migration from Europe to America. Jewish Immigration to America was part of a universal population movement that saw the number of immigrants entering the United States in the years 1815-1860 surpass the nation's population of $1790 .^{9}$ Many of the reasons that caused the English, Irish, and German gentiles to settle in America also pushed the German Jews toward 
the new world. Devastating winters throughout the 1820 s destroyed crops, drove prices up, and bankrupted small tradesmen, village shopkeepers, and marginal farmers. ${ }^{10}$ After 1830 , continuous inflation, urbanization, surplus labor, and a liberal economic system that offered no protection for the lower middle class also spurred immigration. Farmers, shopkeepers, and artisans according to historian Mack Walker were "squeezed out by interacting social and economic forces: a growth of population without a corresponding growth of economic bases, and the increased cosmopolitanization... of the economy."11

In addition to the economic uncertainty of nineteenth century Europe, Jews in the German states suffered from social, political, and economic discrimination. A reaction against Jewish emancipation--won following the French Revolution--set in after the defeat of Napoleon in 1815. ${ }^{12}$ Assaults on Jews occurred in most large German cities. 01d restrictions reappeared, particularly in the southern and western states, governing travel, place of habitation, employment, and marriage. Corporativism was reinstated in some areas, notably Posen, a Polish province annexed by Prussia in varying stages between 1793 to 1815 . A few liberal German states attempted to maintain a semblence of equality for Jews, but efforts to improve the social and economic standing generally failed. Attempts to increase the number of Jewish artisans, an occupation long closed to Jews, failed because of a lack of available jobs and virulent anti-Jewish sentiment among the craft guild leadership. 13

In the 1830 s the worst conditions for Jews were found in the southern German states. And not surprisingly, by 1860 the majority of forefiñ born adult Jews in Portland had immigrated from Bavaria and its 
neighboring states. Bavarians dominated Jewish immigration to most American communities between 1830 and $1860 .^{14}$ An indeterminate number of Jews left Germany after the failure of the revolutions of 1848 . As Bernard Goldsmith, a leading Portland merchant, speculator, and two term Portland mayor noted: "In 1848 there was a general revolution and general dissatisfaction over there [Bavaria] and I did not like things and just made up my mind that I would come here."15 He arrived in the United States in 1849. Many of the "48ers," Jewish and non-Jewish, actual1y immigrated in the early 1850 s as German reaction against liberalism grew stronger. ${ }^{16}$ The number of Portland Jews who immigrated for that reason is unknown. But Joseph Gaston, in his history of Portland, included fifteen biographies of German Jews who were 15 years or older in 1848. Seven of them immigrated between 1848 and 1855.17 While not conclusive, we can safely assume that some of them, and others, fled Europe following defeat of the revolutions.

The Immigration of German Jews continued unabated into the 1870s. By the mid-1860s and certainly into the following decade, the origin of Jewish immigrants to Portland had undergone some change. Comparison of Tables I (Chapter I) and III clearly illustrate the changing character of the immigration during the 1860 s and 1870s. The birthplace of most adult foreign born Jews located in the 1860 census was Bavaria and its neighboring states. But, by 1880 the southern German immigrants comprised only 23.6 percent of the forelgn born adults, while almost 34 percent halled from Prussia. This change, coupled with the increase in Polish Jews arriving in Portland, affected the institutional structure of the community. Polish jews and some Prussians tended to follow more traditional religious practices than the Bavarians, a condition 
which led to the creation of a second congregation in Portland in $1869 .^{18}$

TABLE III

ORIGIN OF FOREIGN BORN JEWS BY SEX $1870-1880$

\begin{tabular}{|c|c|c|c|c|c|c|c|c|}
\hline & \multicolumn{4}{|c|}{1870} & \multicolumn{4}{|c|}{1880} \\
\hline & Male & Fem. & Tot. & $\%$ & Male & Fem. & Tot. & $\%$ \\
\hline Bavaria & 39 & 34 & 73 & 34.0 & 33 & 24 & 57 & 18.4 \\
\hline Baden & 9 & 7 & 16 & 7.4 & 5 & 6 & 11 & 3.6 \\
\hline Wurttemberg & 1 & 0 & 1 & 0.5 & 3 & 2 & 5 & 1.6 \\
\hline Hesse & 15 & 22 & 26 & 12.1 & 10 & 5 & 15 & 4.9 \\
\hline Hambu=g & 1 & 0 & 1 & 0.5 & 0 & 0 & 0 & --- \\
\hline Weimer & 1 & 0 & 1 & 0.5 & 0 & 0 & 0 & --- \\
\hline Prussia & 32 & 16 & 48 & 22.3 & 59 & 45 & 104 & 33.7 \\
\hline Germany, n.d. & 2 & 0 & 2 & 1.0 & 14 & 7 & 21 & 6.6 \\
\hline Austria/Bohemia & 9 & 4 & 13 & 6.0 & 13 & 9 & 22 & 6.9 \\
\hline Hungary & 1 & 1 & 2 & 1.0 & 4 & 2 & 6 & 1.9 \\
\hline France/Alsace & 4 & 5 & 9 & 4.2 & 10 & 6 & 16 & 5.2 \\
\hline Poland & 9 & 11 & 20 & 9.3 & 20 & 11 & 31 & 10.0 \\
\hline Russia & 0 & 1 & 1 & 0.5 & 5 & 1 & 6 & 1.9 \\
\hline other & 2 & 0 & 2 & 1.0 & 8 & 7 & 15 & 4.9 \\
\hline $\begin{array}{l}\text { Total } \\
\%\end{array}$ & $\begin{array}{l}124 \\
57.7\end{array}$ & $\begin{array}{c}91 \\
42.3\end{array}$ & 215 & 100.3 & $\begin{array}{l}184 \\
59.5\end{array}$ & $\begin{array}{l}125 \\
40.5\end{array}$ & 309 & 99.6 \\
\hline $\begin{array}{l}\text { SOURCE: United } \\
1870,1880 \text { (Mic } \\
\text { Oregon. }\end{array}$ & Stat & es $\mathrm{Ce}$ & $\begin{array}{l}\text { isus } \\
\text { ies) }\end{array}$ & Burea & & $1 \mathrm{~S}$ & dule & $\begin{array}{l}\text { of } P \\
\text { Por }\end{array}$ \\
\hline
\end{tabular}

The increase in non-Germans among the foreign born Jews did not, however, change the balance of leadership in the community. Despite evidence that Polish Jews may have been a majority in some parts of the west, ${ }^{19}$ such was not the case in Portland. Moreover, many of the Poles were "Germanized" either in Europe, as a result of Prussian policies In Posen requiring the study and adoption of German culture and language, or in America, in order to integrate with the more numerous German Jews. ${ }^{20}$ For example, Julius Loewenberg, a close friend of Bernard Goldsmith and a dealer in tin and stoves, listed his birthplace 
as Prussia, though he was from Posen. H1s background was not an issue in the community as he became a leader in Congregation Beth Israel and in the First Hebrew Benevolent Association.

The German Jews comprised a portion of the largest immigrant group in Portland. Germans, both Jewish and gentile, accounted for one-quarter of Portland's foreign born population in 1860 and 1870 . And although birthplace tabulations were not made for 1880 , Germans probably remained the most numerous foreign born element in the city. Jews accounted for over one-third of the German born population in 1860 and over one-quarter in $1870 .^{21}$ (Table IV) Because the respective populations were small and they shared a common language and background, strong ties developed between German Jews and German gentiles in the 1860 s.

TABLE IV

FOREIGN BORN JEWS AS PERCENT

OF TOTAL FOREIGN BORN

$1860-1880$

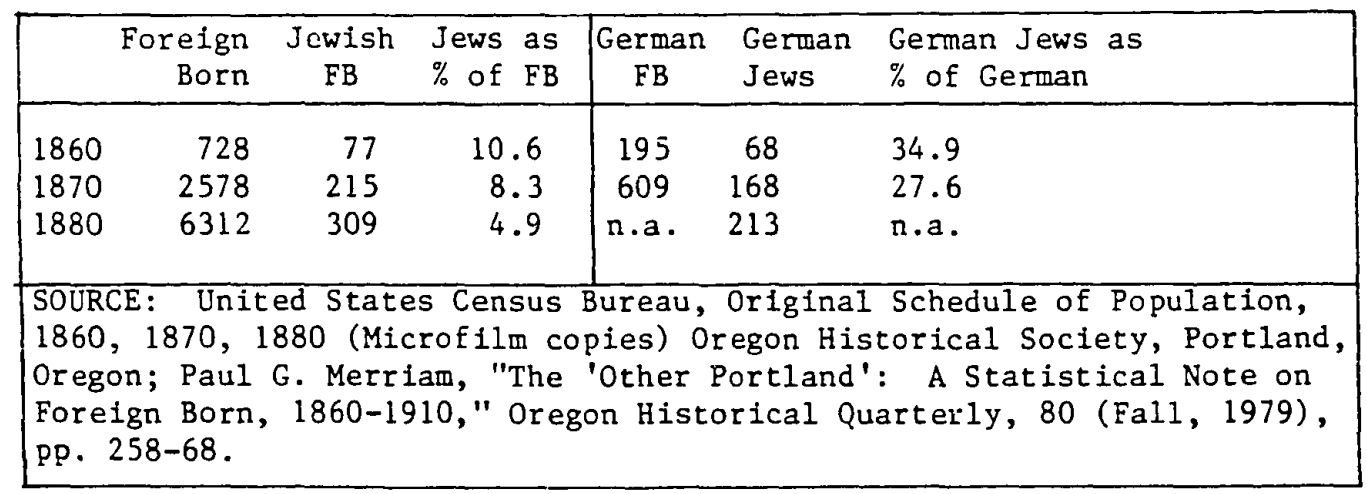

When German Jews arrived in the United States they were loath to discard the German culture and language. German was often the language of the synagogue and in most cases was used in conducting business. ${ }^{22}$ In many locales German Jews jolned in the formation of German cultural 
organizations like the Turnverein, literary and musical societies, and social clubs. 23

A common rural background, recollection of economic distress, and a shared language created a situation in the mid-nineteenth century that brought German Jews and non-Jews together in relative harmony. They shared many social, cultural, political, and charitable interests. ${ }^{24}$ Nowhere was this more apparent than in the cities and towns of the Midwest where Germans settled in vast numbers. Milwaukee, Wisconsin, which by 1865 had a Jewish population of 1500 , boasted a strong social and economic relationship between Jews and non-Jews in the 1850 s and $1860 \mathrm{~s}^{25}$

The German experience in Portland differed in some respects from that in cities of the Midwest. Because most Jews who settled in Portland had lived elsewhere in the United States prior to moving to Oregon, they had already been exposed to American culture and were beginning to adopt English. The West experienced a "second immigration" of people who had first lived in the east and who tended toward acculturation rather than separation. ${ }^{26}$ The records of Jewish organizations in Portland during the years under discussion were kept in English exclusively, unlike the Portland Social Turnverein and the German Aid Society. However, the city's German Jews expressed pride in their heritage and although English was their adopted language and Hebrew was their sacred language, they felt enough affinity for German to require it as a course in the Beth Israel day school which operated from the 1860 s to the mid1870 s. ${ }^{27}$

Jews in Portland participated in German cultural organizations, actively in some cases, passively in others. A Turnverein was established in Portland in 1858. The Turner societies began in Germany as 
physical training societies which stressed liberal and of ten socialist ideals. $^{28}$ Whether Porland's Turnverein espoused socialist beliefs is unknown. Records of the society's early years no longer exist, nor do membership lists from the 1860s. The society's officers included a number of Jews, including Jewish presidents. Few of the fourteen Jewish officers during the 1860 s were also leaders in the Jewish community. Sol Goldsmith, a clerk for J. Kohn and Company in 1862 when he was Turnverein treasurer was president of the Hebrew Benevolent Association in 1864-65. By then Goldsmith was a partner in Elfelt, Weil and Company, a dry goods firm that succeeded Kohn's. Golsmith left Portland by 1870 . Additionally, F. S. Ostheim, Turnverein president in 1863 and 1866, was also president of the Hebrew Ladies Benevolent Society in 1867 and 1868. Only Sam Loewenstein, Turnverein president in 1868 and 1869 advanced in financial and social stature in the city. By 1880 he was president of the Oregon Furniture Manufacturing Company and was a member of the prestigious Concordia Club, a club for the Jewish social elite in the $1880 \mathrm{~s}^{29}$

Dissension enveloped the Turnverein in the early 1870 s and led to is dissolution in May 1871. No record of the dispute exists, but one student of Germans in Portland suggests that it was precipitated by personality conflicts and differences between Republican and Democratic members over the Grant-Greeley presidential campaign. ${ }^{30}$ whatever the reason, the younger members met in August and formed the Portland Social Turnverein, with no Jews included in the new membership. The reorganized society's functions were strictly physical fitness, cultural, and benevolent. 31

Only two men who can be Identified as Jews served as Turnverein 
officers between 1871 and 1885. Ludwig Levy, a Bavarian jeweler in his thirties, who also belonged to B'nat B'rith and Congregation Ahavai Shalom, was an officer throughout these 15 years. Samuel L. Beary, the Oregon born son of a merchant from Turttemburg, served on the Turnverein board in 1878 at the age of eighteen.

The exclusion of Jews from Turnverein membership in 1871 may have been a conscious discriminatory act, or it may have been the result of Jews seeking other avenues of cultural expression, although no Jewish cultural organization existed in the city until 1873. More likely, it was the beginning of a new identification for Portland Jews. While proud of their German heritage and using it to differentiate themselves from their Polish cousins, Portland Jews were beginning to seek greater assimilation into American life. The Hebrew and German school at Beth Israel was in decline in 1871 and 1872. As public education improved, and the community felt less need for their children to speak German, the school's stature dwindled. ${ }^{32}$ On August 25,1872 , at the request of Adolph Waldman and Moses Seller, the Beth Israel Board of Directors voted to use the school house for a separate English school so as not to interfere with the German and Hebrew school. By 1873 the Beth Israel school was reduced to offering two classes every other day for short afternoon lessons. By 1874 the school rooms were being rented to nonJewish teachers for private classes. Instruction by the rabbi remained a late afternoon supplement to public school studies. Religious instruction was given on Sundays. 33

Portland's German Jews assoclated in large numbers with the German Aid Society, a benevolent organization established in 1869 to aid German immigrants in neeu. Before 1885 only Ludwig Levy represented the 
Jewish community among the officers of the society, suggesting that Jews did not play an active role in the administration of the organization or disbursement of funds, a function generally handled by the trustees. The earliest existing membership list for the society is from 1887 and includes eighteen individuals who can be identified as Jews. Several of those were members of the Jewish upper and uppermiddle class social elite that was developing in the 1880 s. Eight of them were memiers of the Concordia Club. Additionally, the membership included several Jewish community leaders who did not join Concordia, specifically Louis Blumauer, Solomon Hirsch, Jacob Mayer, and Philip Wasserman. Presumably, the Jewish leadership lent their names, dues, and benevolence to the German Aid Society, if not their energies. Thirteen of the Jewish members also belonged to the Hebrew Benevolent Association. 34

Jewish membership in the German Aid Society indicated a charitable impulse toward individuals of similar heritage. By the $1880 \mathrm{~s}$, on the other hand, it did not represent a tenacious clinging to German culture. The pioneer Jews accepted the United States as their new home and Americanization came easily. Moreover, in Portland the Jewish population was becoming increasingly native born as the single men who immigrated during the previous decades married and started families.

Perhaps the most important demographic change that occurred among Portland Jewry between 1860 and 1880 was the increase in married couples as a percentage of the adult population. The establishment of families on the frontier signalled a transition from a mobile, unstable population to a permanent, secure component of the city. Just as Congregation Beth Israel was the product of the initial stage of community building, 
the decision by Jewish pioneers to establish permanent residence in Portland resulted in the creation of other organizations designed to serve the needs of a community of families.

The transformation of the Jewish communtty from predominantly single males to family oriented followed a natural progression. Conditions in Europe, where marriage and residence restrictions on Jews produced a large class of single men, encouraged immigration. Unlike the male Irish immigrants who were, in large measure, peasants with families to support and few marketable skills, ${ }^{35}$ the German Jews were petty traders and artisans who were not burdened by familial responsibilities. Once in America, the Jews could move with greater ease from place to place until they found a city or town that met their particular needs and expectations. Over half of the adult Jews in Portland in 1860 were single men, most between the ages of eighteen and thirty. Seventy percent of the adult males were single and they outnumbered single women by more than ten to one. While single men moved onto the frontier in large numbers, single Jewish women did so only in the company of family or friends.

One woman who sought to settle in Portland discovered the perils which could face young women who entered the frontier outside the care of their famtlies. Fanny Hyman, a niece of Portland tobacco merchants Philip and Henry Wasserman, decided in 1858 to move to Portland from Troy, Ohio where she lived with another uncle, Jacob Wasserman. It was arranged that she be accompanied to Portland by Nathan Cohen, a Prussian watchmaker. They travelled to New York City In January, 1858, where they were scheduled to book passage to San Francisco. They stayed in New York with Nathan Hyman, another uncle of Fanny's. The two men 
conspired to detain Fanny until she agreed to marry Cohen, threatening to leave her destitute in New York if she did not accede. Not being allowed to communicate with her relatives for four months, she finally agreed to the union, "protesting and remonstrating against it." The newlywed Cohen's then sailed for San Francisco and Portland in early July. Upon arrival in Portland Fanny left Cohen and took up residence with her uncle, Henry Wasserman. She and Wasserman petitioned the Territorial Legislature to grant a divorce which was aifirmed in December of $1858 .^{36}$ While divorce was uncommon among Portland's pioneer Jews, no stigma apparently attached to Nathan Cohen. He became a member of Congregation Beth Israel and later affiliated with Congregation Ahavai Shalom. 37 Fanny's fate is unknown.

In the two decades following 1860 the percentage of single men in the adult male population dropped significantly to 43.2 in 1870 and 46.6 in 1880 . The slight rise in the latter year resulted, in part, from the immigration of single Geman men who fled the conservative regime of Otto von Bismarck's unified Germany. Many of the Jews who came to Portland in the 1860 s and 1870 s joined relatives who had already established themselves. These new residents, unlike the first Jewish settlers in Portland generally came directly to the city from Europe. Max and Leopold Hirsch arrived in Portland in the 1870s to clerk in the store of their uncle Aaron Meier. They later formed the Hirsch-Weis Company after purchasing Willamette Tent and Awning Company in 1907. Likewise Sigmund Sichel, nephew of Solomon Hirsch, became a clerk in 1873 for L. Fleischner and Company, of which Hirsch was a senior partner. Later in the decade Signund's younger brother Moses left Bavaria to enter his uncle's firm which had become Fleischner, Mayer and Company. 
Bernard Goldsmith, who had family business affiliations in San Francisco, New York, and Munich, sponsored the migration of brothers and nephews to Portland during the 1870 s. $^{38}$

Before the early 1860s, the number of single Jewish women in Portland was so small that many of the men who had attained financial security and were ready to start families travelled to San Francisco, New York, or Europe to seek brides. By 1870 the proportion of single men to single women had decreased to four to one, and by 1880 it was 2.5 to one. The most startling change reflected in the 1870 and 1880 figures concerned the number of married Jews in the population. In 1860 only 44 percent of the adult Jews in Fortland were married, including 82 percent of the women. By 1870 the total married rose to 68 percent and represented a four-fold increase in real numbers over the previous census. The proportional change came almost entirely within the ranks of the male population as early settlers like Levi White, Joseph Bergman, Philip Wasserman, Alex Kaufman, and Aaron Meier started families. The total number of married Jews almost doubled by 1880 , although as a percentage of the adult population the figure dipped to 62 percent. (Table v)

As more marriages occurred among the pioneer Jews of Portland, the number of children in the population increased. In 1860 when single adult males dominated the population, children age 15 years and under accounted for 38 percent of all Portland Jews. By 1870, when many single men had consolidated their positions, married, and started families, the percentage of children in the Jewish population had increased to 49.5 percent. A decade later, as more adults arrived in Portland and many children passed the age of fifteen, the percentage of children 
dropped to thirty-rine. (Table VI)

TABLE V

MARITAL STATUS OF PORTLAND JEWS

18 YEARS OF AGE AND OLDER

$1860-1880$

\begin{tabular}{|c|c|c|c|c|c|c|c|c|c|c|}
\hline & \multicolumn{5}{|c|}{ Males } & \multicolumn{5}{|c|}{ Females } \\
\hline & Tot. & Mar. & $\%$ & Sing. & $\%$ & Tot. & Mar. & $\%$ & Sing. & $\%$ \\
\hline 1860 & 60 & 18 & 30.0 & 42 & 70.0 & 22 & 18 & 81.8 & 4 & 18.2 \\
\hline 1370 & 132 & 75 & 56.8 & 57 & 43.2 & 89 & 75 & 79.8 & 14 & 20.2 \\
\hline 1880 & 236 & 126 & 53.4 & 110 & 46.6 & 172 & 128 & 74.4 & 44 & 25.6 \\
\hline
\end{tabular}

SOURCE: United States Census Bureau, Original Schedule of Population, $1860,1870,1880$ (Microfim copies) Oregon Historical Society, Portland, Oregon.

TABLE VI

POPULATION OF PORTLAND JEWS BY AGE AND SEX $1860-1880$

\begin{tabular}{|c|c|c|c|c|c|c|c|c|c|c|c|c|}
\hline & \multicolumn{4}{|c|}{1860} & \multicolumn{4}{|c|}{1870} & \multicolumn{4}{|c|}{1880} \\
\hline & Male & F em. & Tot & $\%$ & Male & Fem. & Tot. & $\%$ & Male & Fern. & - Tot & $\%$ \\
\hline $0-5$ & 18 & 18 & 36 & 26.7 & 50 & 48 & 98 & 21.0 & 57 & 65 & 122 & 15.9 \\
\hline $6-10$ & 5 & 7 & 12 & 8.9 & 42 & 36 & 78 & 16.7 & 47 & 46 & 93 & 12.1 \\
\hline $11-15$ & 0 & 3 & 3 & 2.2 & 33 & 23 & 56 & 12.0 & 43 & 39 & 82 & 10.7 \\
\hline $16-20$ & 4 & 3 & 7 & 5.2 & 14 & 15 & 29 & 6.2 & 42 & 44 & 86 & 11.2 \\
\hline $21-25$ & 14 & 7 & 21 & 15.6 & 22 & 18 & 40 & 8.6 & 50 & 38 & 88 & 11.5 \\
\hline $26-30$ & 20 & 6 & 26 & 19.3 & 14 & 17 & 31 & 6.6 & 31 & 35 & 66 & 8.6 \\
\hline $31-35$ & 14 & 4 & 18 & 13.3 & 21 & 19 & 40 & 8.6 & 33 & 27 & 60 & 7.8 \\
\hline $36-40$ & 9 & 2 & 11 & 8.1 & 26 & 17 & 43 & 9.2 & 27 & 19 & 46 & 6.0 \\
\hline $41-45$ & 0 & 0 & 0 & -- & 22 & 4 & 26 & 5.6 & 27 & 15 & 42 & 5.5 \\
\hline $46-50$ & 0 & 1 & 1 & 0.7 & 3 & 5 & 14 & 3.0 & 27 & 16 & 43 & 5.6 \\
\hline $51-55$ & 0 & 0 & 0 & --- & 4 & 0 & 4 & 0.9 & 16 & 5 & 21 & 2.7 \\
\hline $56-60$ & 0 & 0 & 0 & --- & 1 & 1 & 2 & 0.4 & 7 & 4 & 11 & 1.4 \\
\hline $61+$ & 0 & 0 & 0 & --- & 2 & 4 & 6 & 1.3 & 6 & 2 & 8 & 1.0 \\
\hline $\begin{array}{l}\text { Total } \\
\%\end{array}$ & $\begin{array}{r}84 \\
62.2\end{array}$ & $\begin{array}{c}51 \\
37.3\end{array}$ & 135 & 100.0 & $\begin{array}{r}260 \\
55.7\end{array}$ & $\begin{array}{l}207 \\
44.3\end{array}$ & ${ }_{3}^{467}$ & 100.1 & $\begin{array}{r}413 \\
53.8\end{array}$ & $\begin{array}{l}355 \\
46.2\end{array}$ & $2^{768}$ & 100.0 \\
\hline
\end{tabular}

The percentage of Jewish children who had been born in the United 
States approached ninety-five percent in 1860 and did not change in 1870 or 1880 . Studying the birthplace of children provides an insight into several aspects of the Jewish migration, settiement, and comunity life in nineteenth century America. The overwhelming majority of American born children in the Jewish community confirms the point that Jewish men emigrated from Europe while single, and established families only upon arrival. By using the "child ladder"--tracing the birthplace of children within a given family--it is likely that we can identify the country in which the parents were married. ${ }^{39}$ Table VII clearly shows that no more than 14.5 percent of the married Jews in any year married and started families in Eurcpe.

TABLE VII

PLACE OF MARRIAGE OR BIRTHPIACE OF FIRST CHILD 1860-1880

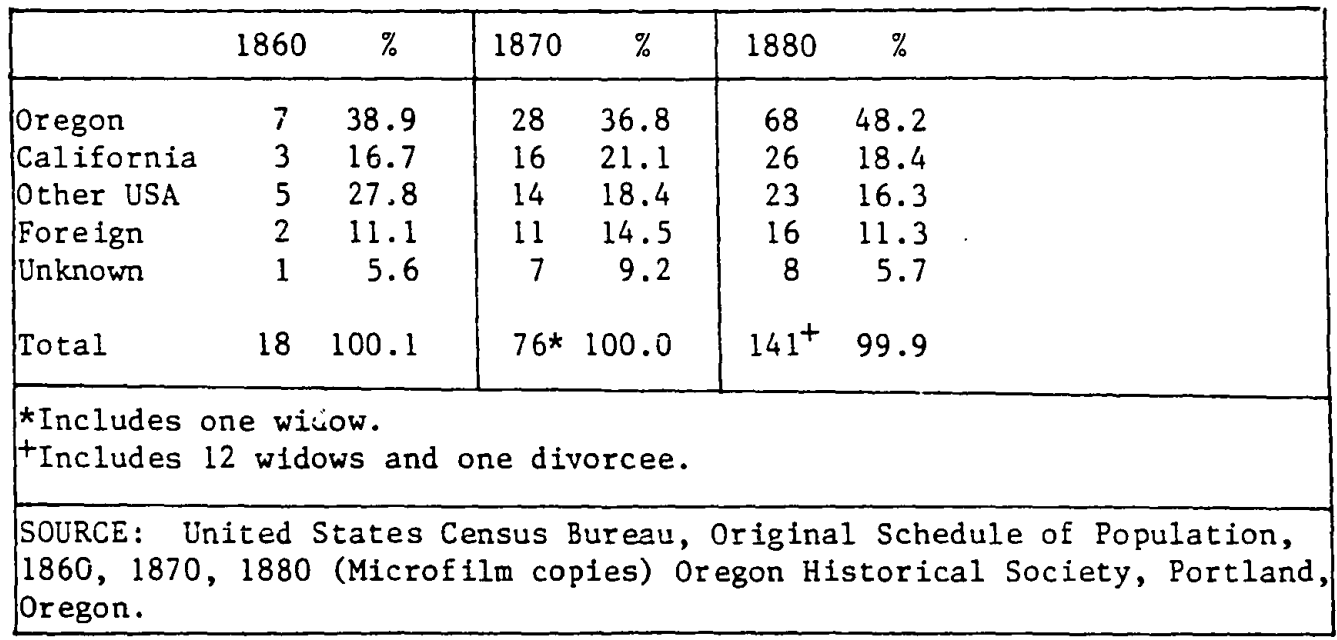

The "child ladder" also reveals the high degree of geographic mobility of Jews on the frontier. While many Jews started families after arriving in Oregon, Table VII indicates that many others began careers and families elsewhere in America or In Canada. For example, David 
Jacobi, a Bavartan bookkeeper and police official, settled in California in the early 1850s, moved to Vancouver Island around 1860, and migrated to Portland sometime after 1862. Prussian produce dealer, later commission merchant, Nillam Gallick left Connecticut in the early 1850 s for California where he remained until at least 1865 before settling in oregon. 40

As the number of native born Jews--particulary children-increased, the community's population became, correspondingly, less foreign born. In 1860 the foreign born element among Portland Jewty was 57 percent, but by 1880 it had decreased to 40 percent. (Table VIII)

TABLE VIII

FOREIGN BORN JEWS AS PERCENT OF JEWISH POPULATION BY AGE

$1860-1880$

\begin{tabular}{|lccc|ccc|ccc|}
\hline $\begin{array}{l}\text { Total } \\
\text { Age } \\
0-15\end{array}$ & $\begin{array}{l}\text { FB } \\
\text { Age } \\
0-15\end{array}$ & $\begin{array}{l}\text { \% FB } \\
\text { Age } \\
0-15\end{array}$ & $\begin{array}{l}\text { Total } \\
\text { Age } \\
16+\end{array}$ & $\begin{array}{l}\text { FB } \\
\text { Age } \\
16+\end{array}$ & $\begin{array}{l}\text { Age } \\
16+\end{array}$ & $\begin{array}{l}\text { Total } \\
\text { Pop. }\end{array}$ & $\begin{array}{l}\text { Total } \\
\text { FB }\end{array}$ & $\begin{array}{l}\text { \% FB } \\
\text { of Tot. } \\
\text { Pop. }\end{array}$ \\
\hline 1860 & 51 & 3 & 5.9 & 84 & 74 & 88.1 & 135 & 77 & 57.0 \\
1870 & 232 & 13 & 5.6 & 235 & 202 & 87.0 & 467 & 215 & 46.0 \\
1880 & 297 & 18 & 5.7 & 471 & 292 & 62.0 & 768 & 309 & 40.2 \\
\hline
\end{tabular}

By 1880 native born individuals constituted 66 percent of the $16-30$ years old age group compared to 32 percent in 1870 and 17 percent in 1860. While this illustrates the aging of young Jews, its importance lies in the effect it would have in the future. Although the early ploneers embraced their new home and sought to adapt to the American way of 11fe, they were still hyphenated Americans with an indelible German 
identity. Their sons and daughters, however grew up with American institutions and education, and matured in an environment that bore little relation to the Europe of their parents. Although their German heritage would provide a distinction between them and the Russian immigrants of the 1890 s and 1900s, they were for all other intents American Jews. The dynamic changes in Portland Jewry in two decades produced far reaching effects in the social and economic structure of the community. ${ }^{4}$ The increase in population created the possibility for organizational development and stability. The growth of families--both nuclear and extended--fostered strong bonds in business and helped build a wellestablished, affluent middle-class community. 
CHAPTER III

THE COMMUNAL IMPULSE

Israel Joseph Benjamin, a world traveler from Moldavia, visited Portland in February 1861 and wrote of the Jewish community: "In spite of the fact that all the Jews living in the State are well-to-do, there is only a cemetery to give visible proof of their religious feeling and needs." He scorned the low salary allotted for the chazan, who was also the Hebrew teacher.

I cannot say much in praise of their benevolence, but, for the sake of historical accuracy, must report just the contrary. They are most stingy. Perhaps the cold and damp climate has affected their hearts and killed every warm feeling. 1

Salary for the community religious leader never reached a large sum, but if Benjamin had remained in the city for three more months, he would have witnessed the laying of the cornerstone for the Pacific Northwest's first synagogue.

Following the creation of the congregation, members of Beth Israel met for services every Friday evening and Saturday morning in Burkes Hall, a loft over a stable and blacksmith shop. In the fall of 1859 the congregation purchased a $100 \mathrm{ft} . \times 100 \mathrm{ft}$. lot from Benjamin Stark for $\$ 750$ and began laying plans for a synagogue. The building was consecrated in August, 1861, with a service officiated by the Reverend Dr. Elkan Cohn of San Francisco's Emanu-E1.2

The presence of Rabbi Cohn at the service commemorating the completion of the synagogue symbolized the bond between the Portland and San 
Francisco religious communities. Beth Israel, besides adopting the constitution of Emanu-E1, borrowed and later purchased the first Torah scroll and shofar (ram's horn blown to announce the Jewish new year) used in Portland from the San Francisco congregation. ${ }^{3}$ Additionally, several of the religious leaders of Beth Israel came from or later moved to San Francisco. 4

For the quarter of a century following the formation of Beth Israel, the congregation experienced continual struggle and turmoil as its members adapted to the social climate of the frontier. Portland Jews were far from the centers of Jewish religious life and had to de: teimine for themselves the type of ritual that best met their needs and expectations. They could turn to the chazan or rabbi for direction, but in more cases than not the congregation found itself at loggerheads with its religious leader. ${ }^{5}$ In this respect, the Beth Israel experience paralleled the general experience found in American Judaism during the mid-nineteenth century. Like most congregations founded in midcentury, Beth Israel was an orthodox institution following a traditional ritual--in this case, the German minhag. And like a large body of the German congregations, it moved inexorably toward a reform stance,

In Europe, the synagogue was the seat of religious law and custom in the community and the rabbi provided the last word on interpretation of the law. In America, however, the European system did not work. Although before 1850 most congregations attempted to pattern their services after the European model, ${ }^{6}$ on the frontier where individual Jews first encountered the rough and open life of the peddler and shopkeeper before thinking of forming a religious organization, the traditional kahal stood little chance of survival. These pioneer: Eought for their 
independence and were not inclined to become part of an authoritarian communal structure.

The attitudes of American Iife leaned toward change--whether it meant minor deviations from tradition, such as the introduction of English sermons by Isaac Leeser in his orthodox Philadelphia congregation, or the more radical steps of allowing mixed seating, organ and choir music, and extensive modification of the prayer book taken by David Einhorn at the reform Congregation Har Sinai in Baltimore.' While larger comunities experlenced doctrinal rifts, secessions of members, and formation of separate congregations, ${ }^{8}$ virtually all congregations were undergoing some kind of change. The modifications in synagogue ritual during the nineteenth century were Americanizations based primarily on the Jews' adaptations to the environment, not the Influence of the German reform movement. Historian Leon Jick observed that "respectability and Americanization were the goals; decorum, reform of ritual, and English were the means." 9 American reform leader Isaac Mayer Wise wrote in 1859: "For our cwn part, we are Jews in the synagogue and Americans everywhere." 10 Thus, with no direction from a central religious authority, and imbued with an independent and democratic spirit, Portland Jews began the struggle to find a common ground of religious beliefs and ritual.

In four of its first five years, the congregation was served by learned laymen. In 1860 an advertisement in the Occident, Isaac Leeser's voice of traditional Judafsm, sought "a gentleman who is capable to act as Minister, Chazan, Shochet, and is also required to teach from 10-15 children in Hebrew," for which the congregation would pay $\$ 1000$ per year. ${ }^{11}$ The German educated Herman Bien accepted the position but 
remained only one year before leaving to pursue a political and journalistic career In Nevada and California. Blen left on bad terms with the congregation, although the nature of the controversy is not clear. The fact that in Germany Bien had studied under David Einhorn, who later became the most radical of American rabbis, suggests that he was too liberal a thinker for Portland Jewry. ${ }^{12}$

For the next two years the congregation was led by Herman Bories, a conservative shoe dealer from Bohemia, who served Portland's Jewish community as shochet, mohel, teacher, and at times chazan, for several. decades, first at Beth Israel and later at Ahavai Shalom. ${ }^{13}$

In 1863 Posen-born Julius Eckman came to Portland--for the first time--to become the first ordained rabbi to serve Beth Israel, despite his traditional Polish background, he had studied under Leopold Zunz at the University of Berlin, the German seat of radical Judaism. ${ }^{14}$ Eckman's background and education were not compatible, but he seemed to meld them into a philosophy of orthodox Judaism that allowed for reform in decorum and certain aspects of worship. Eckman did not fit the role the congregation preferred for its spiritual leader. In fact, the congregation was probably seeking more reform in the law and less in decorum, unlike Eckman who supported changes to enhance the dignity of services, but maintained a serict posture on religious interpretation and would brook no change in the law. Eckman, like Bien, was a journalist. With no chance to start a Jewish press in the limited Portland market and faced with open philosophical hostility from congregation members, Eckman resigned in 1866 and returned to San Francisco. 15 That the congregation was ready fór moderate reform was apparent in 1865 when it joined the Board of Delegates of American Israelites, an 
organization formed in 1859 in an attempt to unite American Jewry. ReIiglous moderates comprised the Board's initial member ship while both Einhorn and Wise rejected 1t. Reform congregations joined in the 1870 s and the Board merged in 1878 with the Union of American Hebrew Congregations, the umbrella of reform Judaism. Membership in the Board of Delegates was probably the final straw for Eckman, who opposed it. ${ }^{16}$

In 1866 Beth Israel advertised for a chazan and teacher "who having passed examination and received his diploma in Germany... be competent to discourse and deliver lectures...."17 The hiring of Isaac Schwab was no panacea for the ills of the congregation. Internal struggles over congregation leadership and the form of ritual to be followed flared at meeting after meeting with fines levied regularly against members for disorderly conduct. ${ }^{18}$ Support for Schwab was split in 1871 and when the Board of Directors was not disposed to rehire him on his terms, he resigned. 19

The struggle between the supporters and proponents of Schwab created the most serious controversy at Beth Israel to that date. In 1869 when the congregation voted to rehire Schwab for two years, he refused the offer, demanding a three year contract. The congregation then voted a one year contract, later compromising on the original two years, which Schwab subsequently accepted. ${ }^{20}$ An article in The Jewish Messenger In October, 1869, claimed that the congregation voted for the twoyear contract while Schwab's opponents were absent from the meeting and that several of those members split from Beth Israel to form Congregation Ahaval Shalom "with the stern purpose to see Judaism ennobled, its forms more 1dealized, but not abolished." 21

Congregation Ahaval Shalow was Incorporated four months after the 
vote cited in The Jewish Messenger, however, evidence of a split from Beth Israel by a portion of its members is inconclusive. Records for Ahaval Shalom do not exist prior to 1912. By checking both the 1912 membership Ilst and a list of congregants in The Jewish Tribune of June 19, 1908, and surveying the Ahava1 Shalom Cemetery, eight names can be found of individuals who belonged to Beth Israel and later joined the new congregation. 22 Whether they left because Schwab was rehired or in general protest over the reforms of Beth Israel is a matter of conjecture. Six of the eight were natives of Prussia and Poland and probably held more traditional views then the majortty of Beth Israel members. One account indicates that "but a handful of men of conservative ideas" organized Ahavai Shalom. ${ }^{23}$ Ten individuals who may have been among the handful are listed in the census of 1870. Most of them were married, in their thirties and forties, and hailed from Prussia, Poland, or Bohemia. Among them was N. Goodman, a dry goods merchant from Posen who had belonged to Beth Israel, but left to become the first president of Ahavai Shalom.

That the congregation assumed a more traditional stance than Beth Israel can be seen through an anonymous letter reprinted in The Jewish Messenger. The author, a member of the new congregation, complained that Beth Israel was attempting to copy the reform congregations of San Francisco and New York. It was:

mimicking third hand here, the fashlonable congregational life of the merchants of New York, which borders closely on nihilism and gentilism. What is to be a synagogue is actually to have every appearance of a radical gentile church, and in its teachings it is to abolish all distinctive marks of the revealed religion of Moses, and set that of reason instead, and that of the reason of every merchant member of those fashionable congregation! 24

The harsh criticism of Beth Israel in 1869 was not justified on 
theological grounds since the changes within the congregation centered on the trappings of worship, not on the ritual itself. Attempts in the 1860 s to institute use of a reform prayer book met with continued defeat. ${ }^{25}$ Changes in decorum and dignity during services were designed to provide a more protestant-like air, to assume a more American appearance, not to emasculate traditional Judaism. The American reform movement, under the early leadership of Isaac Mayer Wise, was an Americanizing influence. It was not until the 1870 s and 1880 s that Reform Judaism began to fully address the issues of the status of divine law, messianism, and Jewish peoplehood. 26

The split between Portland's two congregations widened immediately in 1869 when Ahavai Shalom hired Julius Eckman as rabbi and teacher. Relations between the two congregations, situated within a block of each other on Fifth Avenue, remained cool for several years. Eckman, who remained in Portland for two years, continued his opposition to reform in the pages of San Francisco's Hebrew Observer, a newspaper he once edited. In November, 1869 , just a month before the dedication of the Ahavai Shalom synagogue he wrote, "what avail can be to the men who long ago turned their backs against specially Jewish observances." 27

The synagogues' functions were to provide for the preservation of the customs of Judaism (as defined by each congregation), to educate the young and provide for burying of the dead. ${ }^{28}$ Additionally, the synagogue served as a meeting place for friends and business associates. In larger cities, like New York, synagogues flourished along national, and even provinclal lines, whereby people from the same European locale who followed a particular ritual congregated together, as much socially as religiously. ${ }^{29}$ In Portland men of like interests and backgrounds 
formed the core of the two congregations. While Polish Jews and conservative Prussians made up the Ahavai Shalom membership, German Jews overwhelmingly dominated the Beth Israel membership. Tracing Beth Israel members through the census indicates German Jews (even excluding Prussians) and the native born offspring of Germans formed a signif1cantly greater proportion of the membership than of the total adult population (Table IX).

TABLE IX

CONGREGATION BETH ISRAEL MEMBERSHIP

BY OR.IGIN, $1860-1880$

\begin{tabular}{|c|c|c|c|c|c|c|}
\hline & 1860 & $\begin{array}{l}\% \text { of } \\
\text { Men. }\end{array}$ & 1870 & $\begin{array}{l}\% \text { of } \\
\text { Mem. }\end{array}$ & 1880 & $\begin{array}{l}\% \text { of } \\
\text { Mem. }\end{array}$ \\
\hline Bavaria & 21 & 54.0 & 32 & 41.0 & 25 & 24.7 \\
\hline Baden & 2 & 5.1 & 6 & 7.7 & 5 & 5.0 \\
\hline Wurttemberg & 1 & 2.6 & 0 & --- & 2 & 2.0 \\
\hline Hesse & 6 & 15.4 & 11 & 14.0 & 11 & 10.9 \\
\hline Hamburg & 1 & 2.6 & 0 & --- & 0 & $-\infty$ \\
\hline Prussia & 3 & 7.7 & 10 & 12.8 & 15 & 14.9 \\
\hline Germany, n.d. & 0 & $-\infty$ & 1 & 1.3 & 5 & 5.0 \\
\hline Total German & 34 & 87.4 & 60 & 76.8 & 63 & 62.5 \\
\hline Austria/Bohemia & 0 & --- & 6 & 7.7 & 6 & 6.0 \\
\hline Hungary & 0 & --- & 0 & --- & 1 & 1.0 \\
\hline France/Alsace & 1 & 2.6 & 1 & 1.3 & 5 & 5.0 \\
\hline Poland & 0 & --- & 5 & 6.4 & 6 & 6.0 \\
\hline USA & 4 & 10.0 & 6 & 7.7 & 20 & 19.8 \\
\hline Total & 39 & 100.0 & 78 & 99.9 & 101 & 100.3 \\
\hline
\end{tabular}

Beth Israel's members were the business leaders of the Jewish community. They did not uniformly support the reforms that were taking place in the congregation, but neither did the opponents of reform all 
embrace strictly traditioñal Judaism. Men like Abraham Waldman, a clothing rata1ler from Bavaria, opposed what they viewed as radical departures from Jewish principles, while moderates like Jacob Mayer, co-founder of Fleischner, Mayer and Company, supported limited changes in ritual. Bernard Goldsmith, who a close friend characterized as a "rationalist" and "unitarian;" espoused more radical views. 30

The philosophical differences between members came to a head during the 1870s and culminated in a bitter and violent dispute between the rabbi and conservative elements in 1880. Moses May, a twenty-four year old reform-minded rabbi, was hired by Beth Israel to replace Schwab in 1872. May was described as "a practical and faithful teacher who does his whole duty to his scholars" and delivered sermons that were "wellworded, deep, plain, concise, logical, fearless, progressive, and eloquent...." 31 But he was also a brash, uncompromising, and often tactless reformer. Within a year of assuming the pulpit, May demanded use of Isaac Mayer Wise's reform prayer book, Minhag America. ${ }^{32}$ The congregation rejected the demand in 1873 , but recanted a year later following a blistering letter from May in which he charged that his service to the congregation was being hindered by indifference and a lack of consistency by the members.

And Gentlemen! how is it possible for any minister to do good where there is such a lack of good spirit,... You have no regularity in your school nor in your synagogue, and against all my endeavors to please the Congregation I stand in the midst of a chaos of forms and 1 is very difficult to discern whether to go to the right or to the left.

Shortly after Beth Israel adopted Wise's prayer book and jolned the Union of American Hebrew Congregations, congregation president Charles Friendly attacked what he viewed as an erosion of faith. An opponent of May, Friendly issued a report at the annual meeting of the 
congregation complaining that:

our children will have reason to say that our fathers are not only hippocrytes [sic] but worse than heathens, as that race professes idolatry and practice the same when we profess to be Jehudim but do not practice the good example of our forefathers....

The controversy continued throughout the decade. In 1876 a committee was formed to seek a new rabbi, but May's proponents managed to get him elected in 1877 for three more years. Nevertheless, in 1878 the Board of Directors passed a resolution to advertise for a minister who would use the German minhag. May's supporters again prevailed and the advertisement was quashed. 35

At a special meeting of the congregation in January, 1879, four conservative members leveled a series of charges against May that included insulting the women of the congregation, slandering and blackmailing several members, opening other people's mail, threatening to join the Unitarian Church if Phillp Selling was re-elected president, and being "an immoral man and an unbeliever in the doctrines of the Holy Writ." May was exonerated of the charges by a special committee and on September 21, 1879, was rehired for a two year period by a vote of twenty-eight to ten. 36

In September of the following year May entered into a heated argument with Abraham Waldman in front of the stove and $t: n$ store of Levi Hexter and Levi May. Waldman became enraged and knocked the rabbi to the ground. The two men were separated whereupon May pulled a gun from his coat and fired several shots at Waldman, none of them hitting their target. 38 May subsequently resigned his position, issuing an understated explanation. "Being destrous of promoting harmony in your Congregation and understanding that my resignation as chazan and teacher 
will have a tendency in that direction I hereby tender my resignation..." The congregation voted to give him the balance of his salary, $\$ 1200$, and he left the city. 39

The violent outbreak resulting from the reform controversy at Beth Israel was not unique in the American Jewish experience. Isaac Mayer Wise felt the conviction of his Albany, New York congregants in 1850 when he was physically attacked on the pulpit during services on Rosh Hashanah. However, the struggle for reform generally remained verbal, either in congregational meetings or in the courts. 40

Beside the acrimonious debate over reform, Beth Israel faced serious financial difficulties in the 1870 s, brought on in part by a dwindling membership. Approximately 100 Jews belonged to Beth Israel in 1871. Despite a 67 percent increase in the Jewish population in the seventies, the membership fell to 80 in $1881 .^{41}$ Various means devised to extricate the synagogue from indebtedness included a quaiterly tuition for the German school, sale of the school property, mortgaging the school property, requests for ten members to each sign $\$ 300$ notes, operation of a fair by the "Israelitish Ladies," and creation of a subscription program. ${ }^{42}$ The latter campaign in 1873 failed because opponents of Rabbi May refused to financially support the reforming congregation. Simon Blumauer and Matthias Koshland reported that a lack of harmony existed and "to do justice to one and all we will not take money from our liberal members only." 43

The depression and fires of the decade also hurt the congregation and it did not fully rebound until the mid-1880s. The completion of the Northern Pactf 1c Railroad in 1883 brcight a population surge to Portland that was felt by Beth Israel and new members joined as more Jews arrived 
by rail. A year later the congregation hired Rabbi Jacob Bloch who served Beth Israel for 16 years. Bloch who had been a rabbi in Little Rock and Pine Bluff, Arkansas, and in Sacramento before taking the Portland post, guided Beth Israel into a flourishing period. He shunned the limelight and quietly led the congregation Into the reforms May had espoused during his tenure. ${ }^{44}$ By 1887 Beth Israel's growth created a need for a new synagogue. Louis Fleischner of Fleischner, Mayer and Company organized a subscription fund which raised $\$ 20,525$ from 93 Individuals and seven businesses. A large Byzantine structure very similar to Congregation Emanu-El's Sutter Street Synagogue in San Francisco was completed and dedicated in 1889.45

Little is known of Ahavai Shalom during this period. Two years after its organization the congregation had fifty members and forty-five pupils in its Hebrew school. The wedge that the presence of Julius Eckman on the pulpit drove between the two congregations may have eased in 1879 when Herman Bories became the chazan of Ahavai Shalom. 46 Bories, long a member of Beth Israel, was traditional in his approach to Judaism and may have left Beth Israel during the later years of the May disputes. It is also likely that he accepted the position at a time when Ahavai Shalom needed a chazan and teacher while it searched for a rabb1. Bories had spent his years at Beth Israel acting in just such a capacity.

The first mention of Ahaval Shalom in the records of Beth Israel came in late 1882 when the former requested a meeting of school directors to discuss improvement of Sunday school offerings and instruction. 47 The division that separated the two congregations was easing, although no thought of uniting was ever seriously considered. Differences be- 
between the two synagoglies remained but a closer relationship developed as Portland's Jews gained a social maturity in the 1880s. David SolisCohen, a member of an Influential Philadelphia Sephardic family, symbolized the new relationship. A merchant, lawyer, banker, poet, and author who opposed theological rigidity, he believed in a wholeness regarding Judaism and, in putting his preaching into practice, belonged to both congregations. 48

The dissension that characterized the religious life of Portland Jewry in the 1860 s and 1870 s apparently was not manifest in any great measure in other facets of Jewish communal Iife. The national division between Germans and Poles that partfally explained the split in the religious profile of Portland Jewry remained an issue in social relationships, receiving expression in the 1880 s with the establishment of the Concordia $\mathrm{Club}$ as an institution for the German elite. But for membership in the aid societies, B'nai B'rith, and cultural organizations, being a Jew was the only requirement.

Without the European corporate structures to provide for all their needs, American Jews began to adapt the corporate services to the democratic Institutional 1ife of their new home. During the Colonial and Federal perfods, charity was the function of the synagogue. The Sephardic congregations of the 18 th century tried to emulate the Eurofean synagogue which was the heart of the corporation. That became increasingly difficult as the Jewish population grew. In New York, by 1803, seventeen synagogues were providing charity, loans, burial, and medical aid with little thought given to consolidating their services. Fragmentation along essentially national or provincial lines--an early day 1andsmanschaft--insured the deterioration or disintegration of 
traditional synagogue functions. Not every synagogue could maintain a cemetery, joint administration of the slaughter of animals and preparation of matzoh became impossible, and charity became too diffuse and competitive to be effective. ${ }^{49}$

New York was a special case because of the size of the Jewish community, yet similar problems faced other cities of the East. However, as Jews moved onto the frontier they left behind the fragmented communal life of eastern cities. Virtually all frontier communities established Benevolent Societies to dispense chartty independent of the congregations, again as a reaction to the independence of frontier life. In many cases the charitable organization appeared before the religious body. 50

When the First Hebrew Benevolent Association of Portland, Oregon was incorporated in 1863, four years after it was formed, the prime movers included Levi White and Lazarus Bettman. White, with his brother Isom, settled in Portland in 1858 and opened a dry goods store on Front Street. By 1860 they had accumulated a very modest amount of personal property. The 1860 s were boom times for the Whites and by 1870 Levi White 1 isted $\$ 10,000$ real and $\$ 30,000$ personal property, making him one of Portland's wealthiest Jewish merchants. Bettman began his business career with Simon and Leopold Baum as a clerk in their wholesale dry goods store in McMinnville which was part of a network of establishments operated by the Bettman and Rosenblatt families. 51

By the mid-1860s the proftle of leadership of the benevolent society was firmly established. Young men who had consolidated their positions in Portland's business communtty and had accumulated considerable wealth turned to the charitable organization. Merchants like 
Kalman Haas and Augustus Elfelt served as trustees in 1864 and 1865 . They left the city soon after and their places were filled by merchants Solomon Hirsch, Julius Kraemer, Philip Wasserman, and Bernard Goldsmith. David Friedenrich, a wealthy attorney and one of only two Jewish professionals in the city in 1870 was president during the late 1860s. In the 1870 s and into the 1880 s the driving force in the organization was Louis Fleischner. He and his brother Jacob unlike most Jewish pioneers travelled overland to Oregon by ox team, arriving in 1862. Louis operated a store in Albany until 1859, then peddled goods and engaged in a general merchandise business in Idaho for four years. In 1864 he, Solomon Hirsch, and Alexander Schlussel established L. Fleischner \& Company which merged with Jacob Mayer's wholesale store in 1875 to form Fleischner, Mayer and Company. 52

Perennial trustees during the late 1860 s and 1870 s included wasserman, White, Goldsmith, Hirsch, Kraemer, Julius Loewenberg, and Leon Lewis, all of whom with Louis Fleischner were members of Beth Israel. But more telling for understanding the operation of the benevolent society was that in 1870 they were among the twenty wealthiest Portland Jews, ranging from Kraemer's $\$ 12,000$ to Goldsmith's $\$ 180,000.53$ Although records for the benevolent association do not exist for the years prior to 1884 , a brief sketch of the organization indicates that the wealthier members would disburse charitable funds and receive reimbursement from the assoclation after submitting an itemized 1ist. 54 This loose arrangement differed from synagogue charity in which agreement on disbursement had to be reaclied by the Board of Officers. By the late 1860 s and 1870 s synagogue charity was restricted to free burIals if the family of the deceased had limited means, and donation of 
funds to ald Jews suffering due to catastrophe or epidemic in other locales. 55

The First Hebrew Benevolent Association paid for nursing care, hospital expenses, pharmaceutical costs, funeral costs, and charity to "worthy persons." By 1885 payments were generally made by the treasurer who then received reimbursement from the organization. 56

Quarterly dues of $\$ 3$ were collected from the 104 members in 1885. Capital of over $\$ 15,000$ was loaned out at six to ten percent interest and an additional $\$ 1900$ was placed on deposit. Interest from the loans produced the bulk of the association's income and was probably enough to meet charitable needs. The loans extended in 1885 included two $\$ 5000$ notes to non-Jews and a number of small business notes to members. ${ }^{57}$ Nodel stated that the benevolent association was not associated with Beth Israel in 1859 but that it was run by congregation members. The same held true twenty-six years later. Of the 104 association members in 1885, seventy-one were members of Beth Israel, four were or would be members of Ahavai Shalom, while twenty-nine were unaffiliated or did not appear in congregation records through 1885 . During the 1860 s and 1870 s a handful of men served as officers of both organizations. During this period there was a close relationship between the association and congregation in arranging burials and in the 1880 s the association provided Ioans to Beth Israel. ${ }^{58}$ Nevertheless, charity was dispersed to needy Jews regardless of affillation or origin.

A year after the First Hebrew Benevolent Association incorporated, the first Jewish women's organization was formed in the city, a benevolent society established by wives of local merchants. Ten years later In 1874 it formally incorporated as the First Hebrew Ladies Benevolent 
Soclety of Portland, Oregon, with the expressed purpose "to ald, assist and relieve the poor, needy and sick by contributions of money, provisions, clothing and other necessaries; to prepare the dead for burial and to do all other acts and things usuaily done by Charitable Institutions." 59 The volunteer society served as a mutual support group for young married women whose husbands often left the city on extended busiress trips. The role of the society followed traditional maternal lines--visiting and caring for the sick and comforting the bereaved-in a non-traditional organization. 60

Dues, fines and interest from small loans comprised the funds available for charitable work. Through 1885 the society disbursed no more than $\$ 630$ in any given year for charity, generally in small sums for funeral expenses, to aid families or individuals of limited resources to leave the city, or for the hire of nurses. ${ }^{61}$ while Jewish men provided loans through the First Hebrew Benevolent Association to assist business development, the women's society funds were "exclusively devoted to ladies of the Jewish fatth." ${ }^{62}$ The society found some common ground for cooperation with the men's association--for example, splitting the cost of a full-time nurse--and assisted Beth Israel in its period of financial distress. ${ }^{63}$

Charitable expenditures could be made by individual members, though the regular procedure originally allowed for disbursements by action of the board or by individual authorization of the president. The president and secretary, who made the actual disbursements, were allowed by the Constitution to be men, and both were until 1879 when Cecilie Friedlander replaced Lehman Blum as secretary. In February, 1884, an amendment to the Constitution required that the Bcard of 
Officers approve aii expenditures made by the president. Three months later the president of ten years, Edward Kahn, resigned and was zeplaced by Emma Goldsmith, the wife of former mayor Bernard Goldsmith. ${ }^{64}$

The Ladies Benevolent Society had forty-three members in 1875. By 1886 it increased to seventy-nine and under the leadership of Ema Goldsmith, who Judge Matthew P. Deady described as "a woman of a great deal more than ordinary ability," the society grew to a membership of 177 in 1893 while changing its form of benevolence and administration of capital very $1 \mathrm{i} t \leq 1 \mathrm{e}$. $^{65}$

"Charity was a form of mutual insurance as well as a basic tenet of their Jewish Paith," Nodel wrote of the pioneer Jews. ${ }^{66}$ The benevolent societies created a vehicle for internal stability in the community. As the numbers of Portland Jews increased, the societies acted as a means to insure that their co-religionists would not fall into poverty, while also providing to some an initial business stake. These functions and the family support mechanism inherent in the women's soclety played a central stabilizing role and provided a cohesiveness in the community structure,

Portland Jews recognized the dangers of the frontier and made preparations for burials. Additionally, they recognized that fellow Jews might need some form of assistance in establishing a place in the city. By the mid-1860s as Jewish merchants and artisans began accumulating wealth, investing their capital in the city, and starting families, the need for long range mutual aid became apparent. In 1866 twenty-two men petitioned the District Grand Lodge \#4 of San Francisco to form a B'nai B'rith Lodge in Portland in large part to satisfy their health and death benefit insurance needs. 67 
In 1843 a group of 1 tberal German Jews who wished to unite the fragmented community of New York formed the first B'na1 B'rith Lodge in the United States. The preamble to the B'nal B'rith constitution clearly stated the insurance needs of the members, "providing for, protecting, and assisting the widow and orphan on the broadest principles of humanity." The lodge also served a social, fraternal function and was structured along the 1 tnes of Masonic and Odd Fellow lodges (several founders were members of those fraternal orders) replete with regalia, handshakes, signs and passwords. 68

The Portland lodge, Oregon Lodge 65, was the first organization of its kind in the Pacific Northwest. From an initial membership of about thirty in 1866, the lodge grew to include fifty-seven in 1877 . By 1884 there were seventy-five members in Oregon Lcdge 65 . Seventy-five percent of the members in $1873 \mathrm{remained}$ in Portland In 1884, far exceeding persistence rates for all Jewish adult males in Portland and elsewhere, ${ }^{69}$ thus suggesting that the lodge was an agent of cohesion and a symbol of a stable, permanent community in Portland.

Western B'nai B'rith experfenced some growing pains in the 1870 s. While the national organization was attempting to institute some reforms that would make it look less like a Masonic order, the District Lcdge Executive Council felt disposed to take exception. The Council saw no reason to use Erglish rather than Hebrew titles like Grand Saar, Worthy Grand Baal Hagginze, and Worthy Grand Shomer. "It is a sad commentary upon the state of our Order, which is composed of Jews, to see them trying their best to eradicate all that pertains to Judaism from it." The council did agree, however, that the use of regalia be discontinued. 70 
In Portland more serious matters plagued the membership. A fire In 1872 destroyed the lodge's paraphenalia forcing it to request remittance of $\$ 150$ in dues from the District Lodge. The following year, the great fire of 1873 damaged B'na 1 B'rith property and created a hardship for many members. As a result the Oregon Lodge disbursed $\$ 714.40$ to members, more than twice the payments of San Francisco's Orphir Lodge 21 which had over three times the membership. Additionally, the District Lodge donated $\$ 600$ to Oregon Lodge $65^{71}$

The doctrinal split in the religious community which fell along national lines did not occur in the $B^{\prime}$ nal $B^{\prime} r i t h$, indicating that the desire to obtain mutual benefits was more compelling than provincial cleavages. By tracing members in Oregon Lodge 65 for the years 18661884 through the census, the pluralism of the lodge is clearly revealed. Jews from Bavaria, Prussia, Hesse-Darmstadt, Austria, Poland, France, and Russia found acceptance in the lodge. ${ }^{72}$

An actuarial controversy did embroil Lodge 65 in the mid 1870s. As early as 1873 attempts were made to institute a second lodge in Portland, but the District Lodge would not grant a charter because the Oregon Lodge opposed it. At the 1875 annual meeting the Executive Council reported that the petitioners for a new lodge could not, nor would not, Join the extsting lodge. A letter from Oregon Lodge 65 stated that two lodges could not exist in the city and asked "Will you cut us off in our prime...?" The letter also suggested that the petitioners were old and Infirm and would not form. a healthy lodge. ${ }^{73}$ However, the petitioners eventually carried the day and Pacific Lodge 314 was granted a charter in 1879 .

The charge that the Pactfic Lodge petitioners were old and infirm 
did not bear scrutiny in 1879 (though it may have in 1874). In fact, the opposite was the case. The average age of the thirty-four members of Pacific Lodge in 1879 was thirty-one, and it would have been lower except for the presence of 62 year old Joseph Herris, a clothing merchant from Prussia. The average age of Oregon Lodge members was fortytwo. The wide age disparity was a deterrent to the younger men joining the older lodge because, as William Toll has suggested, "younger men would generally be reluctant to join such a lodge and watch their premiums paid out in benefits to the families of older members."74 Joseph Harris was allowed to join the North Pacific Lodge No. 314 by the younger members because of a District No. 4 rule that disqualified new members over forty-five years of age from participating in the insurance benefits. 75

Most of Pacific Lodge's members in 1879 and into the mid 1880 s were single men who had not advanced in business as far as their counterparts in Oregon Lodge of whom virtually all were married and owned their own businesses. Beside actuarial concerns, the men who formed Pacific Lodge found greater common ground and the possibility for more satisfying social ties among themselves than they could have in the older lodge. 77 The members of Lodge 314 followed the same 1 ines of business as the members of Lodge 65 , the only difference in 1880 being the place in the occupational life cycle. Of the thirty-four inductees in 1879, ten were clerks or salesmen, fifteen listed their occupation as merchant, and the remaining nine were skilled or semi-skilled workers. of the twenty-four members of Oregon 65 located in the 1880 census there were twenty merchants or established entrepreneurs, two artisans, one clerk and one retired. 78 
The organizational framework of Portland's Jews through 1880 was primarily designed to enhance the stability of the community. Even the 11terary soctety formed in 1879 became involved in aid to the needy. The Young Men's Hebrew Association was organized "to promote a better feeline among young men and to unite them in a liberal organization which shall tend to their moral, intellectual, and soctal improvement" and its stated objectlve was "The Protection of Hebrew Interests." 79 By 1882 the YMHA revised its Constitution and By-laws to include as an objective "To mutually assist each other in our general interests and to aid strangers in our city in obtaining employment." A Relief Cominittee was formed to "take notice of all cases deserving their attention and in every way carry out the spirit of our Constitution." 80 The extent of aid provided by the YMHA--or if it ever dispensed aid--is unknown.

The YMHA movement in America was part of the growth of German cultural organizations in the 1850s. After the first YMHA was established in New York in 1851, the associations quickly spread to other cities. They supported reading rooms and libraries for use by young Jews. Lectures, debates, and a variety of cultural events were designed to improve the moral character and intellectual condition of the members. While some events were often social, the YMHAs were not social clubs and generally prohibited card playing and other activities associated with convival organizations. ${ }^{81}$

Like the early YMHAs, Portland's counterpart was almost exclusively German or native-born of German parentage. The 1882 membershif consisted of forty-six active members and ten contributing members. The latter group included long-time Portland residents like Jacob Mayer, 
Joseph Bergman, Louis Fleischner and Samuel M. Lyon who, as contributing members, were required to pay less in annual dues than active members, but who probably underwrote the organization with large donations. All the contributing members were sucsessful merchants or professionals while many of the active members were still clerks or bookeepers. Well over half the YMHA members were single men under thirty years of age and a large portion were the sons of Portland Jewry's leading families. 82 An apparent predecessor to the YMHA was formed in the early 1870 s. The Portland Literary Society appeared in the 1873 City Directory with Samuel Simon, Samuel Beck, Louis Blumauer, and Ben Mayer as officers. All four were native-born sons of local merchants. ${ }^{83}$ The Society disappeared from subsequent directories and its function and reason for failure are unknown.

The Portland YMHA disbanded by 1894 and its failure was lamented in the Jewish press in the 1890 s. $^{84}$ The reasons for disbanding probably centered on limited financial support as the cost of establishing a library and maintaining a reading room may have weighed heavily on the relatively small membership.

The communal organization of Portland Jewry during the "German era" was complete in 1887 with the reorganization of the Concordia Club. Founded in 1879 by young clerks and merchants, the club soon became the province of the Jewish elite, maintaining a decidedly German character. 85 Whereas the early immigration had been almost entirely German, and Beth Israel had become a gathering place for the old German families, Concordic represented just such an enclave in a population that was becoming increasingly non-German in the $1880 \mathrm{~s}$ and $1890 \mathrm{~s}$.

By 1880 Portland Jews supported an insular organizational framework 
that gave group Identity to their ethnicity. However, the congregations, benevolent associations, B'na1 B'rith lodges, and literary societies were not created in a social vacuum. The structure and profile of each organization reflected the environment in which it developed, and the changes in form that evolved during the previous two decades indicated a desire to adapt to and become part of the host society rather than withdraw into a traditional, isolated sub-group. The pioneer Jews embraced the democratic spirit of the frontier and modelled their organizations to fit into it. The result of this development was the relatively easy movement of Jews in the life of the city with the security of having a community structure that could meet the various needs peculiar to their Jewish identity. 
CHAPTER IV

OCCUPATION, PERSISTENCE AND ECONOMIC MOBILITY

Lamenting what he viewed as an erosion of Judaic tradition in Portland's Jewish community, an anonymous author wrote in 1869 that "the religious state of our people here is like that everywhere else in the United States: it is business that absorbs the thoughts and civilities of men."1

Though overstated, there is a ring of truth in the comment. Portland Jews entered the trades familiar to them, drawing on their European experience, and quickly developed modestly successful enterprises. From a handful of small general merchandise shops in the 1850 s the Jewish trades burgeoned into sophisticated wholesale, importingexporting, and speciality businesses by 1880 . After three decades of economic evolution, Jews virtually dominated the city's clothing industry, and owned a large share of the tobacco, furniture, and wholesale stores. 2 The success of Portland's Jewish businessmen was built on a combination of singleness of purpose, familial business nuturing, and sophisticated credit and trading networks.

Restricted in Europe to the petty trades and peddling, Jewish immigrants in the mid-1800s followed the lines of business they had known In Europe with peddling and small shopkeeping becoming the principle occupations of Jews who moved to the frontier in 1840. Continually moving to new locales in search of better markets, the peripatetic Jew 
became a figure that has become a legend in frontier life. The Jewish peddier was a near heroic íigure who shunned cicy life and cracked the countryside selling his goods to farmers and in small towns, of ten to other immigrants with whom he shared a common experience and language. Stories abound of the peddlers who accumulated enough money to open a retail store in a small town or village, then advanced to wholesaling in a larger market, and finally created a financial emptre. ${ }^{3}$ The truth for the great majority of peddlers, however, lay midway along the path from rags to riches. Peddling was not a ronantic enterprise. It was a harsh and lonely existence, as described by historian Howard Morley

Sachar:

The plaint must have been of ten repeated by immigrant sons, lying friendless and alone in Midwestern country inns, listening to the call of strange birds in the woods, the raucous laughter of raw-boned frontiersmen rising from the public rooms belcw. ${ }^{4}$

Still, the peddlers general success was formidable and economic security was the reward.

The Portland market was a rung on the occupational mobility ladder. Because peddling was a transient occupation it cannot be known how frequently peddlers came to the city or how many lived in Portland when not on the road, nor is it possible to ascertain how many men first peddled in Oregon before establishing permanent stores in Portland. The Weil brothers, Abram, Moses and David, peddled goods in the 1850 s in Washington and Yamhill Ccunties. David Weil was a resident of Portland in 1853 and his two brothers were listed on tax assessment roles in Yamhill County from 1854 to $1859 .^{5}$ In 1860 they all lived in Portland and by mid-decade Abram and Moses managed Weil Brothers, a dry goods store, and David was a partner in Elfelt, Weil and Company, also 
a dry goods firm. ${ }^{6}$ The Weils left Portland by 1870 .

The Weils' experience as peddlers-turned-merchants in the same locale was not the norm for Portland Jews. As previously indicated the early Jewish pioneers arrived in Portland after spending a few years in other places, generally New York or California. The fourteen foreign born Jews listed by Joseph Gaston whose dates of arrival in the United States and Portland can be traced averaged six years between initial settlement in America and arrival in Portland. ${ }^{7}$ Thus, most Jews who settled in Portland had previous business experience and came to the city to establish small stores, either on their own or as branches of firms in other cities or towns.

The departure of the Weils from Portland in the 1860 s was indicative of Jewish geographic mobjlity. Persistence in the decade (measured by their appearance in both the 1860 and 1870 census) accounted for only 27.9 percent of those men who listed occupations in the 1860 census. This suggests that for Jews who came to the city in the late 1850 s, Portland was simply a stopping point along the road to economic success.

Over 61 percent of the Jews who did not remain in Portland through the decade had accumulated less than one thousand dollars. That would seem to suggest a correlation between economic and occupational success and persistence. However, the same percentage of Jews who did remain also had accumulated under $\$ 1000 .^{8}$ One of the problems with studying the 1860-1870 persistence is that the bulk of the population immigrated to Portland in the late 1850 s and had not had time to attain much wealth. The capital they did accumulate was refnvested in order to insure a solvent business in the fragile economic atmosphere of a 
frontier urban center.

Some individuals who arrived and departed in the 1860 s remained in Portland for several years before leaving, and during that time they became fairly wealthy. Julius and Kalman Haas operated a successful grocery in Portland until they sold their business to Louis Fleischner in 1864 and extablished a more successful firm in San Francisco. ${ }^{9}$ Some others left the city almost upon arrival. Sigmund Schwabacher, a 19 year old clerk who worked for the Waterman brothers in 1860, left Portland the next year to join his brothers in Walla Walla. They supplied farmers, miners, and pack trains with general merchandise. By 1863 they had branches in four towns, and at the end of the decade the Schwabacher enterprise had spread to Seattle and San Francisco. ${ }^{10}$

In turn, the men who arrived without measurable assets and who remained through the $1860 \mathrm{~s}$, consolidated their positions in the economic community. Of the ten persisters who listed $\$ 1000$ or less in property In 1860 , all accumulated substantial wealth by 1870 with six, in fact, listing over $\$ 10,000$. Aaron Meier claimed $\$ 30,000$, tobacconist Philip Wasserman claimed $\$ 42,000$, and merchant Henry Bloch claimed $\$ 26,000$, including $\$ 20,000$ in real estate.

Despite the ambiguities in the figures for the 1860s, persistence can be linked to economic success and stability. Studies of Jewish communities in Atlanta, Columbus, and Los Angeles indicate that economic stake and property ownership are key elements in geographic stability. The rate of persistence in a locale, according to historian Steven Hertzberg, "tells us much about the quality of the Jewish experience in a given locale, an Indication of satisfaction with present place and 
future prospects." 11

The 1860s was a decade of tremendous growth and change in the Jewish community in Portland. The seventeen adult males whe remained from 1860 were joined by over 100 additional males (not including sons of the persisters who had reached the age of 18 during the decade). Portland in the 1860s witnessed an influx of young men, many with families, who would establish stable, permanent businesses.

Persistence rates for the 1870 s give a far more accurate picture of the community than those for the 1860s. Table $X$ indicates a fortyseven percent persistence rate for Portland Jews from 1870-1880, which although considerably lower then exhibited for Atlanta Jews for the 1870 s ( 56.4 percent) and Los Angeles Jews for the 1880 s ( 54.7 percent), represented a greater stability than shown by immigrant and native born groups in Omaha, Poughkeepsie, Atlanta, New York, and Lcs Angeles. 12 It, also, may have been twice the persistence rate of Germans in Port1and. 13

TABLE X

PERSISTENCE BY MARITAL STATUS

1860-1870 AND 1870-1880

\begin{tabular}{|c|c|c|c|c|c|c|c|c|c|}
\hline & \multicolumn{3}{|c|}{ Married } & \multicolumn{3}{|c|}{ Single } & \multicolumn{3}{|c|}{ Total } \\
\hline & Tot. & - Per. & $\%$ & Tot. & Per. & $\%$ & Tot. & Per. & $\%$ \\
\hline $\begin{array}{l}1860 \\
1870\end{array}$ & $\begin{array}{l}18 \\
75\end{array}$ & $\begin{array}{r}8 \\
39\end{array}$ & $\begin{array}{l}44.4 \\
52.0\end{array}$ & $\begin{array}{l}42 \\
57\end{array}$ & $\begin{array}{r}9 \\
23\end{array}$ & $\begin{array}{l}21.4 \\
40.4\end{array}$ & $\begin{array}{r}60 \\
132\end{array}$ & $\begin{array}{l}17 \\
62\end{array}$ & $\begin{array}{l}28.3 \\
47.0\end{array}$ \\
\hline
\end{tabular}

of the Jews who remained in Portland through the 1870 s almost forty-four percent owned some real estate in 1870, and forty-seven 
percent had accumulated over $\$ 4000$ in real and personal property. of those who had persisted since 1860 , eighty-two percent owned some reai estate and sixty-four percent had accumulated more that $\$ 4000$ (Table $\mathrm{XI})$. The latter figures suggest that as the length of residence increases, the economic stake becomes greater. Further evidence of the correlation between persistence and wealth is seen in the figures for non-persisters. Forty-flve percent of those who left Portland during the 1870 s had accumulated less than $\$ 1000$ in personal weal th by 1870 . However, a quarter of them owned real estate. The fact that such a large number owned real estate, and that 16.4 percent of the nonpersisters claimed assets of $\$ 10,000$ or more, indicated that there was still an urge to seek more fruitful markets (Table XII). J. S. Rosenbaum, a tobacco merchant who with his brother operated branches in New York and San Francisco, left Portland in 1874 after accumulating $\$ 22,000$ to concentrate on business in California. Likewise, Max Goldsmith, who received his business training from his uncle, Bernard Goldsmith, settled in New York where he became a partner in the east coast branch of L. Goldsmith and Company. ${ }^{14}$

Persistence is 1 inked to two other factors--marital status and occupational mobility. Over three quarters of the single males in Portland in 1860 left the city by 1870 compared to only fifty-six percent of the married males. The out-migration of married men in the 1870 s decreased to forty-eight percent, and the incidence of single men leaving dropped to sixty percent. This change in the mobility of single men could have resulted frcm an increase in the number of single females of marrlageable age. Additionally, as the community's population growth slowed in the 1870s and established business firms expanded, more young 
TABLE XI

WEALTH IN 1870 OF JEWS PERSISTING 1860 TO 1870

\begin{tabular}{|ccc|c|c|}
\hline \multicolumn{3}{|c|}{$\begin{array}{c}\text { Tot. } \\
\text { Prop. }\end{array}$} & $\begin{array}{l}\text { Real } \\
\text { Prop. }\end{array}$ \\
\hline $0-1000$ & 1 & 9.1 & 0 & ---- \\
$1001-4000$ & 3 & 27.3 & 4 & 36.2 \\
$4001-7500$ & 0 & ---- & 1 & 9.1 \\
$7501-10000$ & 2 & 18.2 & 1 & 9.1 \\
$10001-15000$ & 0 & --- & 1 & 9.1 \\
$15001-20000$ & 0 & --- & 0 & ---- \\
$20001-30000$ & 2 & 18.2 & 1 & 9.1 \\
$30001+$ & 3 & 27.3 & 1 & 9.1 \\
& 11 & 100.1 & 9 & 81.8 \\
\end{tabular}

TABLE XII

PERSONAL AND REAL WEALTH OF PERSISTERS AND NON-PERSISTERS $1870-1880$

\begin{tabular}{|c|c|c|c|c|c|c|c|c|}
\hline \multirow[b]{2}{*}{$\$$} & \multicolumn{4}{|c|}{$\begin{array}{c}\text { Persisters Wealth } \\
1870\end{array}$} & \multicolumn{4}{|c|}{$\begin{array}{c}\text { Non-Persisters Wealth } \\
1870\end{array}$} \\
\hline & $\begin{array}{l}\text { Total } \\
\text { Wealth }\end{array}$ & $\%$ & Rea1 & $\%$ & $\begin{array}{l}\text { Total } \\
\text { Wealth }\end{array}$ & $\%$ & Rea1 & $\%$ \\
\hline $0-1000$ & 18 & 29.0 & 2 & 3.2 & 30 & 44.8 & 3 & 4.5 \\
\hline $1001-4000$ & 15 & 24.2 & 15 & 24.2. & 16 & 23.9 & 6 & 9.0 \\
\hline $4001-7500$ & 6 & 9.7 & 1 & 1.6 & 5 & 7.5 & 5 & 7.5 \\
\hline $7501-10000$ & 8 & 12.9 & 2 & 3.2 & 5 & 7.5 & 1 & 1.5 \\
\hline $10001-15000$ & 5 & 8.1 & 1 & 1.6 & 2 & 3.0 & 1 & 1.5 \\
\hline $15001-20000$ & 2 & 3.2 & 0 & --- & 4 & 6.0 & 1 & 1.5 \\
\hline $20001-30000$ & 3 & 4.8 & 1 & 1.6 & 3 & 4.5 & 1 & 1.5 \\
\hline $30001+$ & 5 & 8.1 & 1 & 1.6 & 2 & 3.0 & 0 & --- \\
\hline Total & 62 & 100.0 & 23 & 37.0 & 67 & 100.2 & 18 & 27.0 \\
\hline
\end{tabular}

men were needed for sales, clerking, and bookkeeping. Besides providing a vehicle for learning the mercantile trades, clerking generaIlyallowed 
young men to accumulate enough capital to consider marrying and starting a family. Of the 23 single men who persisted in the 1870 s, eleven married by 1880 .

Standing in the occupational strata played an important role in the persistence of Jews, particularly in the 1870s. While the percentage of merchants ${ }^{15}$ in the work force decreased in successive census years, the percentage of merchants persisting through each decade ran approximately ten points higher than the population at large (Tables XIII and IX). Over eighty-two percent of the persisters in 1860 were merchants compared to seventy-two percent of the work force. Similarly, the group that persisted to 1880 was comprised of 69.4 percent merchants in 1870 compared to 59.7 percent of the whole work force.

TABLE XIII

OCCUPATION OF PERSISTERS

1860-1870 AND $1870-1880$

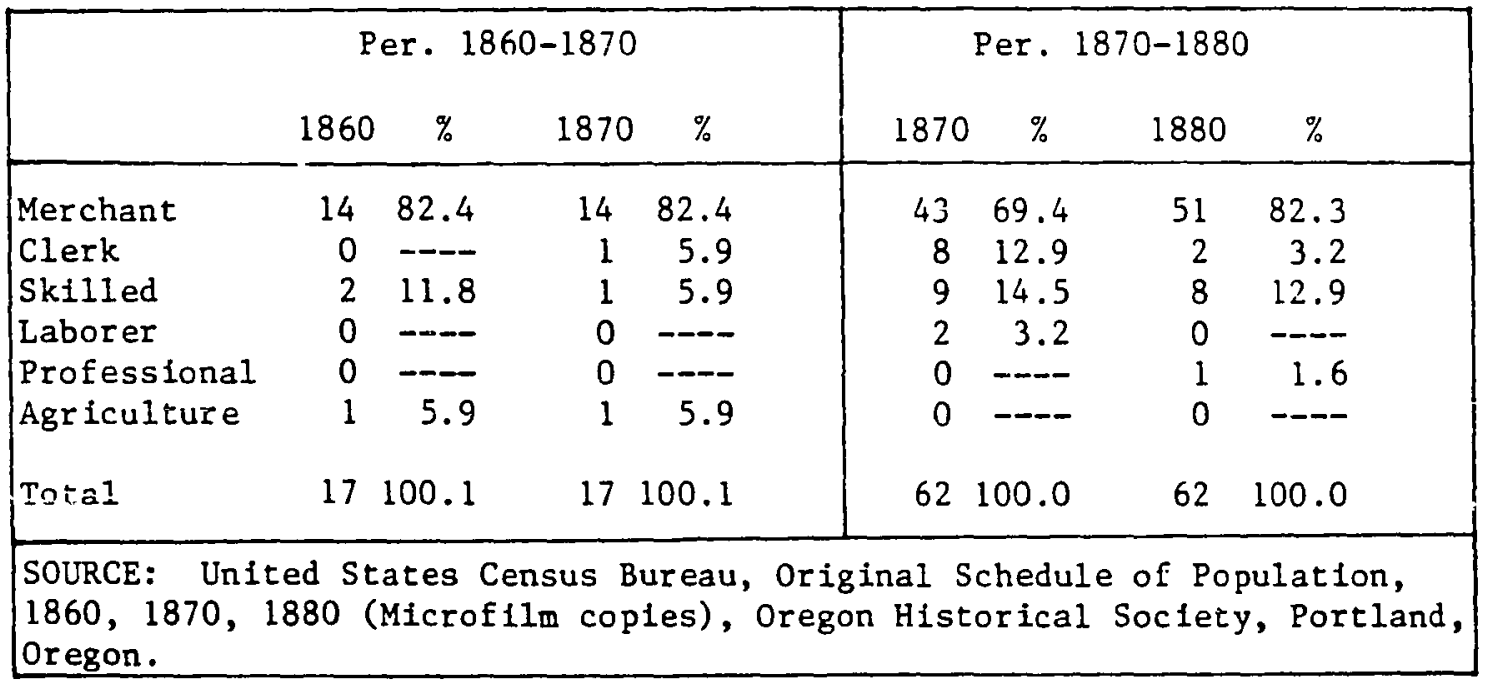

The marital, occupational, and economic status of the persisters provides an explanation of the values that defined stabllity for the 
community. How those factors changed during the persisting decade reveals the social and occupational mobility of Portland Jews. As noted previously, young Jews married after establisining an economic stake in the community. The fact that two-thirds of the single persisters married by 1880 offers some proof of advancement in business and economic success. A clearer picture can be drawn from the changes in occupation. The number of men identified as merchants did not change among those who remained in Portland through the 1860 s. However, mobility was in evidence as butcher Joseph Bergman advanced from the low-skilled labor occupation into the mercantile class, as a grocer. Downward mobility may have occured for Joseph Bachman who listed himself as a merchant in 1860 and a clerk in 1870. However, Bachman accumulated $\$ 10,000$ by 1870 , including $\$ 2000$ in realty, a fact that conflicts with his occupational status as a clerk. Only one other clerk in either 1860 or 1870 owned real estate, Lehman Blum $(\$ 2000)$, and with the exception of Anson Goldsmith $(\$ 5000)$, none had accumulated more than $\$ 3000$ in personal wealth.

The 1860-1870 cohort exhibited upward and downward mobility of 5.9 percent respectively while 88.2 percent remained in the same occupationa1 strata. The 1870-1880 group of persisters was far more occupationally active as twenty-one percent moved upward, over seventy-four percent maintained their positions and almost five percent skidded to a lower strata. This change is characterized by the movement of young men from the clerking ranks in 1870 into the merchandising trades as propietors by 1880 . Ten of the thirteen upwardly mobile Jews of the decade were between 18 and 30 years of age in 1870. Levi May, for example, clerked for his father in 1870 and at 27 years of age had already accumulated $\$ 2000$. In 1880 he was a successful stove and tin dealer in 
partnership with Levi Hexter.

The findings for Portland's Jewish occupational mobility concux with those of Atlanta and Los Angeles concerning the IImits of mobllity. Most Portland Jews belonged to the proprietor, professional, managerial, and official class for whom there was less potential for upward movement once that status was attained. ${ }^{16}$ Immigrant groups generally had several strata through which advancement could occur. Most Italians in New York in 1880 belonged to the unskilled labor class and while their infitial mobility was limited, the potential for advancement was great. 17 In Portland only one unskilled laborer could be located among the city's Jews. There were skilled and sem1-skilled workers in significant numbers, but even in that case many were tailors like Issac Bloom or Marks Rybke who built successful businesses and could be classified as merchant-tailors, or proprietors. Theoretically, then, the chances for "skidding" or downward mobility were greater than upward mobility for Jews of the period. The Atlanta study found that to be true for the Jews who persisted from 1870-1911 as downward movement tended to occur among older Jews who had entered the merchant class and then dropped from 1t. ${ }^{18}$ Two of the Jews in Portland who experienced downward mobility in the 1870 s were over 35 years of age in 1870 .

Mobility can be further understood by studying capital accumulation. If a persisting group remains occupationally stable, as in the case of the 1860-1870 cohort, mobility can be viewed in terms of changes in the type of proprietary occupation and in degree of capital accumulation. A small retaller may enter the fmporting or wholesaling arena as Louis Fleischner, Jacob Mayer, and the White brothers did or become a manufacturer as in the case of Sam Lowenstein. Those movements of ten 
occur in concert with increased financial success. All the persisters. from 1860 to 1870 substantially increased their worth, from Nathan Loeb who lisied $\$ 1200$ in 1860 and $\$ 3200$ in 1870 to Samuel M. Lyon, one of the founders of Beth Israel, whose wealth grew twelve fold from $\$ 3500$ to $\$ 42,000$. The accumulation of wealth and relative occupational stability suggests that the 1860 s was a period of consolidation for those who remained in Portland, a hypothesis which gains more credence when $1 t$ is noted that ninety-four percent of those individuals acquired real estate by 1870 .

Occupational statistics by marital status provides a picture of the life cycle of Jewish businessmen in the 1860 s to 1880 s (Table XIV). Single men, almost exclusively, made up the class of clerks in the community while three quarters of the merchant class were married in both 1870 and 1880 ( 76.6 percent and 74.8 percent respectively) which further indicates the link of occupational mobility to marital status.

TABLE XIV

OCCUPATIONAI CLASS OF PORTLAND MALE JEWS BY MARITAL STATUS $1860-1880$

\begin{tabular}{|c|c|c|c|c|c|c|c|c|c|c|c|c|}
\hline & \multicolumn{4}{|c|}{1860} & \multicolumn{4}{|c|}{1870} & \multicolumn{4}{|c|}{1880} \\
\hline & $M$ & $\mathrm{~s}$ & $\mathrm{~T}$ & $\%$ & $M$ & $\mathrm{~S}$ & $\mathrm{~T}$ & $\%$ & M & $\mathrm{S}$ & $T$ & $\%$ \\
\hline Merchant & 15 & 30 & 45 & 73.8 & 59 & 18 & 77 & 59.7 & 83 & 29 & 112 & 44.3 \\
\hline Clerk & 0 & 4 & 4 & 6.6 & 0 & 26 & 26 & 20.2 & 8 & 57 & 65 & 25.7 \\
\hline Professional & 0 & 0 & 0 & --- & 1 & 1 & 2 & 1.6 & 5 & 7 & 12 & 4.7 \\
\hline Skilled & 2 & 7 & 9 & 14.8 & 13 & 8 & 21 & 16.3 & 28 & 28 & 56 & 22.1 \\
\hline Unskilled & 0 & 0 & 0 & $--\infty$ & 1 & 0 & 1 & 0.8 & 0 & 1 & 1 & 0.4 \\
\hline Other & 1 & 0 & 1 & 1.6 & 1 & 1 & 2 & 1.6 & 1 & 0 & 1 & 0.4 \\
\hline Unknown & 0 & 2 & 2 & 3.3 & 0 & 0 & 0 & --- & 3 & 3 & 6 & 2.4 \\
\hline Total & 18 & 43 & 61 & 100.1 & 75 & 54 & 129 & 100.2 & 128 & 125 & 253 & 100.0 \\
\hline
\end{tabular}


The steady increase of clerks in proportion to merchants in each succeeding decade suggests that the growth of individual businesses required more and more employes. Where two or three partners could handle the buying, selling, and collecting trips as well as manage the store in the 1850 s and 1860 s, by the mid-1870s it was necessary for larger stores to hire clerks, bookkeepers, and salesmen. The large size of Jewish families meant that local merchants were creating their own work force. ${ }^{19}$ The sons, and sometimes daughters, of Bernard Goldsmith, Aaron Beck, Philip Selling, and Jacob Mayer all received their first exposure to business in their fathers' stores. Thus, much of the increase in the number of single clerks was the result of the second generation reaching maturity.

Over sixty percent of the single clerks in 1880 were males new to the city. Some of these young men were native born like George Franklin whose family operated clothing stores in New York, San Francisco, and Portland and sent him to Portland to learn the trade. Still others were foreign born relatives of Jewish merchants who were sponsored to America and became clerks in the firms of uncles and cousins. Twenty year old Moses Sichel, one of the dwindling number of Bavarian imigrants in the 1870s, worked for his uncle Solomon Hirsch in 1880 , later establishing a clothing store in eastern oregon. 20

The increase in skilled and semi-skilled laborers among Jews in 1880 resulted from a growing immigration from Prussia and Poland, as well as an in-migration of artisans who had been in the United States for many years, but who arrived in Portland only after 1870 . Herman Wise, a 40 year old Hungarian tailor, came to America in mid-decade after two children had already been born, settled first in California 
then migrated to Oregon in 1876 or 1877 . Likewise, expressman Mortic Gerstle started a family in Europe in 1870 and settled in Portland at mid-decade. 21

Over seventy-flve percent of the employed Jews in Portland in 1880 held white collar jobs (all individuals in the merchant, clerk, and professional classes). Although lower than the corresponding figures for Jews in Atlanta ( 84 percent), and Los Angeles ( 80 percent), the Incidence of Portland Jews wearing white collars far outstripped non-Jews. 22 While their European background determined the trades they entered in America, Jewish success hinged on and was fostered by family and ethnic bonds. Intra-group business networks that linked Portland with New York and San Francisco, as well as the small settlements of the Oregon hinterland, provided training for young Jews, facilitated extension of credit, and fostered commercial success. The fragility of the frontier economy coupled with the often limited capital Jews held upon arrival in Portland, insured a struggle for economic survival. Lacking capital in reserve, Jews and all other businessmen, had to depend on the extension of credit for survival during times of recession. Attaining credit depended upon receiving a good rating based on investigation of business assets, liabilities, and histories of the principle partners. ${ }^{23}$

The principle rating agency in the country was the R. G. Dun and Company of New York. Credit, by Dun's definition, meant "assets plus character." Peter Decker has shown that in San Francisco R. G. Dun . agents assumed that Jews were of low or questionable character despite their level of assets. Therefore, Jews could not easily find credit from the gentile banking and investment houses. ${ }^{24}$

Dun records for Portland's Jewish businesses displayed some of the 
same characteristics as in San Francisco. The incidence of poor credit ratings and derogatory notations in Dun reports, particularly where a businessman is identified as a Jew, was significant enough to assume that the agents discriminated against Jewish businessmen. A. Burchard, of Burchard and Powers, dealers in second hand furniture, was characterized as "a close fisted Jew" while another report warned that Aaron Meier was "shrewd, close \& calcultg..." and "is considered tricky... it is said that if hard pushed would take care of his private interests before those of crs." 25 While a few firms like L. Goldsmith and Company received good ratings ("the firm heäis a first class reputation") 26 based on the local standing of one or more partners, Dun investigators generally gave negative reports or admonished caution about Jewish businesses.

Jewish business enterprise had to depend on a network of branch merchandising, familial enterprise and insulated credit arrangements. The essence of this networking is evident in a Dun report on $\mathrm{J}$. S. Rosenbaum and Company, a wholesale tobacco and cigar firm. Rosenbaum, In partnership with Nathan Hirstel, maintained credit with A. S. Rosenbaum (a brother) and Company of San Francisco and a New York firm of the same name. The Dun investigator noted, 'We learn from excellent authorities that they have a credit with A. S. Rosenbaum of San Francisco to the amount of $\$ 25,000$. A. S. Rosenbaum nakes nearly all their purchases, but in their name and acts as their Banker." 27

Many of Portland's successful Jewish businesses were branches of family firms in San Prancisco and New York. Firms like Walter Brothers, dealers in imported and domestic carpets, and Neustadter Brothers, a wholesale clothier, had branches in the three cities, each 
managed by a relative. A few Jewish businessmen like Bernard Goldsmith maintained ties with family businesses in Firope. 28

Portland firms were subordinate to San Francisco wholesalers throughout the period, although the growth of local wholesale houses and manufacturers in the late 1870 s and 1880 s began to free Jewish businessmen from that domination. 29 Beyond the New York and San Francisco connections, Portland businessmen created a merchandising network throughout Oregon and the Washington Territory that included establishing branches in smaller markets or staking friends or relatives with a credit of goods. Akin, Selling, and Company, a dry goods house managed by American-born Ben Selling in the 1880 s, sponsored friends and family in small towns like Prineville, Pendleton, and Joseph. ${ }^{30}$

The relationship between Jewish businessmen in the Pacific Northwest included more than an avenue for receiving credit. Some Portland firms interceded on behalf of businesses in the interior for the purchase of Insurance. Ben Selling, for example, used his influence--and co-signature--to obtain insurance for the merchandise of $M$. Kaminsky and Son of Cheney, Washington. Additionally, the business network provided a system for facilitating collections. Selling, for example, asked his friend Sig Sichel, who was IIving in Goldendale, Washington Territory, in the mid 1880 s, to hire an attorney for the collection of a post-due account in that towa. 31

Portland Jews were conservative in their business arrangements, although a few men, like Bernard Goldsmith and Joseph Teal, were continually involved in speculative enterprises and took risks with their capital. 32 But they were atypical among Jewish merchants. Selling was a conservative businessman who scorned the "liberal" lifestyle of some 
young men. He engaged in land and comodity speculation, but was very careful, desiring to insure that the venture was "an excellent investment." 33

The branches that Portland Jewish merchants established served as the training ground for young family members or friends. The training of the younger generation was taken seriously by the elders and was supposed to be accomplished to the exclusion of other interests. Sel1Ing adamantly subscribed to the system and was not above the blunt expression of displeasure when a "trainee" did not exhibit the same view. His young cousin Julius Wertheimer apparently enjoyed the company of a young woman as much as he desired to run a store. Selling advised him:

you must positively let women alone and cards also, if you want your friends to assist you and respect you... When you have made enough money so that you can support a wife it will be time to pay attention to women, until then fet them all severely alone or you will surely regret it. 34

When Wertheimer continued his errant ways, Selling threatened to remove him from the business. Within a month of that warning, Selling transferred Wertheimer to Joseph, Oregon with the admonition that he was sent there

to get you away from bad company and try to make a man of you... You are not up in the country for your health... but tc make and save money. It will not be long before your father and mother will depend entirely on their children for support. 35

The trades were the dominant occupation of Portland Jews, whether as proprletors, clerks, or artisans. By 1880 a handful of professionals appeared in the Jewish workforce, invluding physicians Marcus Mellis and Julius Auerbach, both older men, who were new to Portland during the decade. On the other hand, young attorneys like Henry Ach and 
Joseph Simon were sons of Oregon ploneers. While professionals represented only 4.7 percent of the workforce in 1880 , that figure was more than double over 1870. As the Jewish community attained economic stability and the children of affluent families reached maturity, more sons chose to follow a different occupational road than their fathers. The success of Jews in the business world cannot be told only in terms of the major personalities like Jacob Mayer, Bernard Goldsmith, Ben Selling, and the White brothers, The majority of Jewish merchants operated relatively small or medium size retail outlets. The Hirstel Brothers, bookdealers and grocer Jacob Mitchell who managed modest, but successful businesses more accurateiy represented the emerging stable and affluent middle class community.

With a European background in the mercantile trades where economic survival was marginal, Jewish immigrants were psychologically prepared to challenge the rigors of nineteenth century business life. The success of Jewish merchants In Portland mirrored the experience in other cities where the Jewish population remained relatively small and where it entered the commercial life of the city at the same time as nonJewish businessmen. Despite a few barriers, like credit discrimination, Jews enjoyed the same opportunities as gentiles.

Jews were part of the economic profile of Portland almost from its founding. Because the community was in a stage of expansion, there was room at all business levels for the small number of Jews who chose to stake their future on the banks of the Willamette River. 
CHAPTER V

JEWS IN THE LIFE OF THE CITY

The occupational restrictions placed on Jews in Europe had forced them to cluster in the petty trades and artisan pools. Concentration in those occupational strata produced in the Jews of central and northern Europe a value system that transferred to America and enhanced their chances for success in adapting to a new environment. Milton M. Gordon argues that their European condition meant "the Jews arrived in America with the middle-class values of thrift, sobriety, ambition, desire for education, ability to postpone immediate gratifications for the sake of long range goals, and aversion to violence already internalized."1 In that respect the Jews who migrated to Portland in the third quarter of the nineteenth century held values similar to their gentile counterparts.

That Jewish businessmen played a role in city building from the early stages of Portland's development was important in their integration into the whole of community life. That fact was lost on neither Jew nor non-Jew. From the moment that an organized social life developed in Portland, Jewish participation was evident. When local merchants met to form Portland's first Masonic lodge, Jacob Goldsmith and Levi May were present, and as Willamette Lodge No. 2 completed its first decade in 1860 , fourteen Jewish merchants were or had been members. ${ }^{2}$ All these men were shopkeepers, with a few like Henry Wasserman and 
David Weil experiencing considerable success, which suggests a selective emphasis of the fraternal order. The lodge, particularly on the frontier, provided a socializing mechanism that sanctioned the creation of a middle class solidarity that transcended national and religious boundaries.

In 1861 Portland had two Masonic lodges, one Odd Fellow lodge, and a Royal Arch Chapter. ${ }^{3}$ The 1860 s and 1870 s witnessed a proliferation of secret fraternal orders in the city until in 1880 there were at least thirty lodges representing over half a dozen orders. ${ }^{4}$ The orders of the Masons and Odd Fellows held the greatest attraction for the city's business and professional leaders, including those prominent Jews who were disposed to joining fraternal organizations. During this period Jewish community leaders like Jacob Mayer, Sam Lowenstein, Philip Selling, Julius Kraemer, Joseph Simon, and many others played active rales in local lodges. Bavarians, Prussians, Poles and Bohemians all were invited to membership. The only prerequisite was the proper degree of occupational standing. Thus Posen-born Henry Damz1ger, a successful cigar dealer and president of the Ahavai Shalom Cemetery Association joined the Mayers and Sellings on an equal footing in the Willamette Lodge. 5

In the mid-1860s the Minerva Lodge of the Independent Order of Odd Fellows was established apparently with a predominately Jewish membership. All of its officers in 1867 were German Jews. It is likely that the lodge was created as a German chapter with an initially dominant Jewish membership since German lodges were common throughout the nineteenth century in communities with a substantial German population. Fidelity Lodge No. 120 in San Francisco, like Minerva, began with a 
Jewish majority, as did Harmony Lodge No. 142 in Milwaukie, Wiscon$\sin ^{6}$

In lesser numbers, Jews became members of other secret fraternal orders like the Red Men, Druids, Foresters, United Workmen, Chosen Friends, and Knights of Pythias. The measure of acceptance in the councils of those orders can be understood by studying the positions Jews attained. Jews were conspicious in the frequency with which they appeared on the lists of officers, particularly for the Masons and odd Fellows. Jacob Mayer, who began his Masonic career in San Francisco in 1852 and belonged to Willamette Lodge No. 2, was Grand Treasurer of the Grand Lodge of the Free and Accepted Masons of Oregon--Masonry's governing lodge in the state--in 1881-1883 and was Grand Master, the pinnacle of Masonry, in 1888.

Not all of Portland's leading citizens, Jewish and non-Jewish, adopted the fraternal order with the fervor of Jacob Mayer. Matthew P. Deady, a close frlend of Solomon Hirsch and Bernard Goldsmith, described the rituals of the secret societies as pretentious "Masonic Mummeries." 8 Goldsmith, and undoubtedly several other Portland Jews, joined a masonic order more as a duty required by his station in the community. He wrote in 1889 "I am a Mason although I have never taken any active interest in it." 9

Fraternal participation is a good barometer of Jewish acceptance in Portland, although the community was not without its opponents. Thomas Dryer, editor of the Daily Oregonian during the fifties and perennial candidate for political office, directed his nativist pen toward the city's Jewish population in 1858, charging that they exhibited "duplicity in all social intercourse with the gentile world... 
overreaching and cheating in trade..." 10 After defeat in a race for the territorial legislature Dryer sought a scapegoat, and because the German community was large and visible, his anti-foreign sentiment found a target. And the German Jews were a particularly easy mark. He wrote:

The Jews in Oregon, but more particularly in this city, have assumed an importance that no other sect has ever dared to assume in a free country. They have leagued together by uniting their entire numerical strength to control the ballot boxes at our elections. 11

The Oregon Statesman, an unalterable foe of the Daily Oregonian characterized Dryer "an irresponsible libeller... without integrity or honor," whose "object was to proscribe men on account of their birth place and their religion." The Statesman suggested that the Germans and Jews did vote against him and that his "follies and impudence have driven all honest and consistent men from his support...."12

The vitriol in print derived more from the animosity between the two newspapers than an issue of political anti-Semitism. The Statesman may have been correct when it claimed that "the Jews, as a class" opposed Dryer's candidacy. Considering his political philosophy they had good reason. Nevertheless, four years earlier when Dryer was narrowly defeated for mayor by William S. Ladd, he received four of the eleven Jewish votes in the election. 13

Available city election records indicate that Portland Jews did not form a voting block in the 1850 s and 1860s. Only in elections in which a candidate completely dominated the vote, as in James O'Neill's 1857 mayoral victory over Henry Corbett, did the Jewish vote approach unanimity. Even In 1861 when Henry Wasserman, a Jewish tobacconist and brother of future mayor Philip Wasserman, was narrowly elected city 
treasurer, he managed only ten of eighteen Jewish votes. ${ }^{14}$

Analysis of voting records for the period is full of potential hazards. The Civil War era was a watershed in the political life of American Jewry. Prior to the election of Abraham Lincoln most Jews belonged to the Democratic party, but northern Jews who opposed slavery switched their allegiance to the infant Republican party. Following the war an indeterminate number of Jews returned to the Democratic ranks, particularly when Ulysses Grant ran for president. General Grant's expulsion of Jews from the Tennessee Department in 1862 on charges of war profiteering left bitter feelings in the hearts of many American Jews. However, most remained Republican into the twentieth century. 15

The absence of evidence makes it difficult to determine the affiliation of the vast majority of Portland's Jews. Bernard Goldsmith, elected as Republican mayor of Portland in 1869 noted:

I was a strong Union man during the war. I was a denocrat [sic] before the war. I voted and worked with the republicans [sic] after the war broke out. At the second election of Grant I quit and went back to the old school; to the democratic [sic] party. 16

Goldsmith's close friend and business associate in several speculative adventures, Joseph Teal, was also a Democrat before and after the war. Teal, an ardent supporter of Joseph Lane, the leader of Oregon's Democratic Party and candidate for vice-presiuent $\mathbf{f}_{\overline{11}} 1860$, wrote to Matthew Deady prior to the state convention in December 1859:

But if we can secure the election of 1860 by electing a good sound Democrat, - One who can and will do somthing [sic] besides love the dear people, -One who will stick to the constitution and the rights of the South, Oregon will then enfoy the blessings of a Once more united Democratic party. 17

Like Lane, however, Teal's support for Southern rights was an 
Ideological belief in states' rights, not an expression of pro-slavery sentiment. In the late 1850 s Teal became the only Jew in Oregon to own a slave when he purchased the "negro boy Cole and his grandmother" from a man named Southworth and subsequently gave them their freedom. ${ }^{18}$

Portland Jews viewed local politics and political office as a iueañs of advancing the development of their adopted city. Holding office was almost a duty required of the foundirg fathers. Merchants Augustus Elfelt, A. Rosenheim, Sigmund Rosenblatt, and attorney Morris Fechheimer all served on the Common Council in the 1860 s and 1870 s. Leon Lewis, Henry Wasserman, and Joseph Bachman combined for eight terms in the City Treasurer's office and David Friedenrich was City Attorney in $1868 .^{19}$

For four consecutive terms beginning in 1869 Goldsmith and Philip Wasserman held the mayor's office. Both men typifled the merchant politician who viewed the city with pride and strove to improve its beauty and services. Goldsmith was responsible for the initial purchase of forty acres for City Park (now Washington Park) and forced an ordinance through the Common Council requiring store owners to plant shade trees outside their stores. Wasserman expressed his optimism about the city's future in his annual message of 1872, requesting funds for parks and recreation. 20

Both Goldsmith and Wasserman faced serious issues that required tough, often unpopular positions, and neither should be viewed as merely a booster in office. In the 1860 s the clty witnessed an influx of Chinese laborers who came to work as truck gardeners and wood cutters. Ant1-Chinese sentiment ran high on the west coast as "Workingmen's Associations" sprang up calling for the removal of the Chinese. ${ }^{21}$ In 
1865 several moves were made by the Portland Common Council to tax the Chinese and prohibit their residence in the city. The proposed ordinances were vetoed by Mayor Henry Failing or dropped af ter the city attorney issued negative opinions. ${ }^{22}$

Many prominent Jews found themselves in the middle of the furor over the Chinese. On June 19, 1873, Mayor Wasserman approved a health ordinance that required 550 cubic feet of space for each occupant of an apartment, a measure directed at the Chinese who generally crowded together in rooms with as little as 100 cubic feet per person. ${ }^{23}$ Two days later, Wasserman struck down an attempt by the Common Council to prohibit Chinese laborers being employed on city contracts. He argued that it conflicted with the laws and treaties of the United States and that "the power to act in this matter in my judgement lies solely with the Congress of the United States."24

Ralph and Isaac Jacobs, owners of the Oregon City woolen mills, hired Chinese labor in 1869 and the Oregonian accused them of acting "agalnst the peace and welfare of the community." 25 when white laborers struck the mill following the employment of the Chinese, the proprietors hired more Chinese. On November 23, 1872, the mill was destroyed by fire, believed to have been set by anti-Chinese agitators. ${ }^{26}$

The anti-Chinese forces were led by Irish laborers who felt their jobs were being given to Orientals who would work for lower wages. ${ }^{27}$ But a large portion of the German mercantile class also opposed the Chinese, including some Jewish shopkeepers. Their opposition may have taken form as a means to draw the trade of white laborers. In 1885 Rohn's Clothing store ran a poem in an advertisement in the Oregonian that read, in part: 
Our boys with coolies can't compete, So what's the use of trying?

So Chinese John gets all the work

through white men avaricious. 28

The advertisement appeared in the midst of a wave of anti-Chinese violence in the Portland vicinity in which the Chinase were forcibly expelled from Oregon City, Albina, and Mount Tabor. ${ }^{29}$

Despite some Jewish opposition to the Chinese, the leaders of the community rose to their defense and the defense of aivil order. In February and March, 1886, anti-Chinese forces threatened to expel the Chinese from Portland, causing Mayor John Gates to call out the militia, double the police force, and deputize over 200 citizens. Goldsmith and Wasserman were among the men responding to the crisis. Ben Selling also answered the call and testified to the seriousness of the problem:

We have been threatened with serious trouble on account of the Chinese agitation. At Oregon City the Anti-Coolie club drove the Chinamen out of town during the night. The better class of citizens deprecate this and here in Portland have enrolled about two hundred deputy sheriffs. I am one and have done patrol duty two nights... I think the organization of citizens will prevent any Riot, but if there is one some body is going to be hurt.

The show of strength by the "better class of citizens" preserved the peace and order, and though isolated acts of violence against the Chinese community continued, it never again was threatened by mob violence. Portland's Jews, as a group, and the merchant class, in general, respected civil order and finding any of them among police records was a rarity. Tempers flared at times, as in the confrontation between Rabbi May and Abraham Waldman, or the sibling disagreement between Emil and Aaron May in which the former was charged with defacing a building and assaulting and threatening to kill his brother. But generally the 
violations of the law committed by Jews included citations for minor infractions. Mortic Gerstle was cited for operating an express wagon without a license, M. Wertheimer was cited for driving over a bridge faster than a walk, and Philip Selling violated an ordinance that prohibited "keeping a sign over the sidewalk." 32

On the other side of the law, only a few Jews sought to join the militia or police force. Benjamin Norden, whose family had been in the United States for over two generations, was the Multnomah County Sheriff during the late 1870s. 33 A. Rosenheim, a Common Council member in 1865 and 1867, was elected town marshall in July 31,1867 in a close vote of the council. He appointed deputies and tried to assume office; however, Henry Hoyt, the previous marsha11, refused to surrender the office, claiming Rosenheim's election was illegal. For two months the dispute raged leaving Portland with two non-functioning police forces and often using the services of the county. Although the State Supreme Court ruled against Hoyt, Rosenheim did not assume office. The vacancy was filled by David Jacobi, a 37 year old Bavarian Jew who had yet to advance beyond the occupation of bookkeeper. He was not considered for the post the following year and was defeated in 1869 and 1875 in attempts to become marshall and police captain, respectively. He later served one year as a policeman before being discharged in October, $1871 .^{34}$

Fire occupied the imagination of Portlanders throughout the nineteenth century. Desplte the growing number of brick buildings, Portland was still a city of wood-frame buildings. Fires plagued the city, ranging from the catastrophic fires of 1872 and 1873 that destroyed large sections of the business district to individual fires of natural or incendiary origin. ${ }^{35}$ Several Jewish merchants were victimized by fire 
in the 1870s including Henrietta Ach, S. Levy, Simon and Leopold Baum, Moses Seller, H. Wolf, and as previously mentioned Aaron Meier, Henry Sinsheimer, and the Jacobs brothers. 36

An observer in 1861 felt Portland had the best fire fighting system on the west coast, supporting three fire engine companies and a hook and ladder. ${ }^{37}$ However, the non-professional crews were composed entirely of volunteers. Whereas Jews did not take an active role in police and militia functions, many participated in leadership roles in the various engine companies, including attorney Joseph Simon who became president of the Board of Delegates of the Fire Department in the late 1870 s.

Simon studied law in the early seventies when business in his father's dry goods store slowed. He joined the firm of John H. Mitchell in 1872 , but it was dissolved when Mitchell was elected to Congress. Simon became a leading corporate lawyer during the next decade and developed a political power base that made him the most powerful Republican in the state. He aligned with Henry w. Corbett, Solomon Hirsch, and Jonathan Bourne in the 1880 s and 1890 s to oppose his old mentor Mitchell. During his career, Simon served on the Common Council (1877-1880), in the State Senate $(1880-1891,1895-1898)$, as Mayor of Portland (19091911), United States Senator (1898-1903), and Chair of the State Central Committee of the Republican Party $(1880-1886) .{ }^{38}$

In 1882 State Senator Simon wrote legislation that created the first professional fire department in the city. He subsequently stepped down as head of the department. The first president of the new Board of Commissioners was Jewish merchant Henry Ackerman. ${ }^{39}$

Simon's legislation creating a fire department sprang from a 
commitment to the welfare of the clty, while another important piece of legislation directed toward city services was pushed by Simon in an effort to consolidate his power in Portland. The Board of Police Commissioners, created in 1885, was a three member citizen board that had complete authority over the Portland Police Department. ${ }^{40}$ Fifteen years earlier Portland's first permanent, salaried police department had been established, in part through the efforts of Mayor Bernard Goldsmith. His concern was that the force was too small to insure the security and safety of the community. ${ }^{41}$ Simon's concern was to minimize the strength of the Mitchell Republicans in municipal politics. Two of the three men appointed to the first commission were simon and Bourne. The maneuver succeeded, initially, though by the late 1890s the commission and police department were foundering in scandal. 42 Portland's Jewish merchants did not disproportionately enter the political arena, though their representation exceeded other ethnic groups. Similar to the gentile business community whese leaders played important political roles in Portland and the state, many of the Jewish business elite sought elective office or lobbied for particular causes. Simon, like his non-Jewish counterparts Bourne and Mitchell, was a professional politician. The other Jews who delved into politics were not, although Solomon Hirsch and Ben Selling, both prominent merchants, showed signs of political prowess. Hirsch served in the State Senate from 1874 to 1885 Including one term as Senate President, and in 1889 President Benjamin Harrison appointed him the United States Minister to Turkcy, a post he held until 1892. He lacked the ruthless drive for power that characterized Simon's approach to politics. Hirsch, promoted by Simon, falled to defeat Mitchell for U.S. Senate in 1885 because he 
refused to cast his own yote for himself. ${ }^{43}$

Selling was a staunch Republican, like Hirsch and Simon. While he did not enter political life until the $1890 \mathrm{~s}$, he used his influence to help elect or defeat office seekers. In 1886 he engaged in a letter writing campaign urging his friends and business associates to work for the defeat of a candidate seeking the Republic Party nomination for the State Supreme Court who he termed "a jew-hater [sic]." Selling exhibited some political savvy in cautioning that the 1ssue of race not be raised "as that would only help him in many cases." Selling's efforts succeeded. Supporters of the defeated candidate then sought to unseat Simon as Chair of the Republican State Central Committee. Selling again used his pen, this time in support of his friend Simon. 44

The Jewish leadership, or more accurately, the wealthier Jewish merchants and professionals, took an active interest in the civic and business life of the city. Men like Goldsmith, Wasserman, and the White brothers sat on the boards and associations that oversaw the orderly development of Portland. With William Ladd, Henry Corbett, Reverend Thomas Eliot and others, they worked toward a common end.

The career of Bernard Goldsmith is an example of the Jews' relationship to and view of Portland, althought it was atypical in the breadth of his activities and influence. His political contributions noted above were overshadowed by the extent of his business involvement in promoting city growth. He boasted with justification that "I have been Identified with almost everything that has been going on in this town since I came here." 45

Goldsmith settled in Portland in 1861, already a wealthy man followirg a successful jewelry trade in northern California and southern 
Oregon. ${ }^{46}$ In 1865 with Addison and I. M. Starr, Asa Harker, and Philip Wasserman, Goldsmith formed the first national bank on the west coast. The institution held deposits from the companies of the founders, but experienced little growth over the next four years. In 1869 Henry Corbett and Henry Failing purchased the interests of the Starr brothers and transformed the bank into a financial empire--The First National Bank of Portland. Coldsmith had stepped out of the picture in 1866, though he maintained a large deposit for L. Goldsmith and Company. ${ }^{47}$

In the late 1860s Goldsmith entered the transportation and shipping business on a large scale. He claimed that he and J. McCracken were responsible for the first direct shipment of wheat to England. ${ }^{48}$ Whether that claim is accurate does not change the fact that he was involved in early direct trade with Liverpool, nor does it diminish the importance of that trade. Prior to 1868, wheat bound for England was sold to brokers in San Francisco. Direct shipment to England allowed Portland merchants to sell at lower prices, expand their markets, and thus maximize profits. Goldsmith's role may have been as important as he claimed since by 1869 he operated a brokerage in Portland. 49 Goldsmith participated in the controversy over the north-south railroad and found himself aligned with the California interests in opposition to the Oregon Steam Navigation Company (OSN) directors. Two companies competed for the Portland to Californta line, one on the east side of the Willamette River and one on the west side. The directors of OSN, the shipping company that nonopolized the Columbia River trade, backed the west side because they belleved connection with California could be delayed, thus protecting their interests longer. ${ }^{50}$ Goldsmith supported the east side company. He invested $\$ 20,000$ in the company in 
1868 and with Wasserman, J. C. Hawthorne, and Hamilton Boyd was part of the group that initially graded five or six miles south of Portland before selling out to Ben Holladay. ${ }^{51}$ Hawthorne and Boyd resided on the east side and, in that light, their support can be understood. Goldsmith may have supported the east side line because it would have connected with California much quicker, a desire fostered by his interests in California. Another explanation of his east side support could be Goldsmith's belief that the OSN monopoly--and any monopoly--ran counter to Portland's best interests. In 1868 he and Joseph Teal Incorporated the Willamette Falls Canal and Lock Company and began construction of a system that would facilitate river shipping between Portland and Eugene City. They hoped to break the monopoly of the People's Transportation Company (PTC) above the falls. The state provided $\$ 200,000$ for construction, but it ultimately cost $\$ 400,000$ and Goldsmith bore the brunt of the overrun. 52 When the locks were completed, PTC refused to utilize them. Goldsmith then built several boats and incorporated the Willamette Falls Transportation Company in 1873. For two years he competed with PTC and even challenged OSN on the Columbia. OSN retaliated by entering the Willamette trade. ${ }^{53}$ The existence of three shipping lines on the Willamette and the fact that Holladay's railroad reached Eugene drove prices so low that Goldsmith could not remain solvent. He attempted to sell the locks to the state but a bill to purchase the system was defeated in the State Senate by the Holladay forces. In 1876 Goldsmith sold his company to OSN at a loss of perhaps $\$ 225,000 .^{54}$

Goldsmith maintained that despite his losses, the enterprise had been a worthwhile venture: 
I have always claimed that the greatest benefit I have been to this state was in bullding those locks and canal...The whole carrying trade was in the hands of a monopoly which retarded the growth of the country by the freight rates they charged but as soon as the locks were built it prevented them from charging exorbitant prices for freight. That was a great thing for this state and for this city. They could not see it for a while but have seen it since. I was the only one that suffered by it but it benefitted the state very much. 55

Goldsmith never fully recouped his losses following the sale to OSN.

His penchant for speculation resulted in further hardship in the 1880s when several Idaho mines in which he had an interest failed. 56

Judge Matthew Deady, a close friend of Goldsmith, noted that Goldsmith's speculation often mirrored his desire for civic improvement. 57 Certainly no other Jewish businessman of the period exerted as much influence or affected the economic life of the city to the extent Goldsmith did. Notwithstanding his financial misfortune in the Willamette Falls enterprise, he remained an influential and respected member of the community.

The most important civic organization of the 1870 s and 1880 s was the Board of Trade, the forerunner of the Chamber of Commerce, The business leaders of the city served on the Board and its committees, including the handful of Jews whose success or prestige paralleled Ladd, Corbett, Reed, and banker David P. Thompson. Goldsmith, Wasserman, Hirsch, Isom White, Louis Flelschner, and Julius Loewenbergall held positions on the Board. Benjamin I. Cohen, member of a prominent Baltimore family, was assistant secretary and statistician to the Board. In 1887 he helped incorporate the Oregon Bank, then known as the Portland Trust Company. He was elected bank president in 1890 and remained in that position for twenty years. 58

The cultural 1ife of Portland, like any other urban center, 
depended upon the existence of an educated, wealthy, leisure class for its sustenance: From a limited offering of church choir recitals and small band concerts in the 1850 s and 1860 s, Portland fostered musical, literary, and theatrical organizations through the efforts of its leading citizens. ${ }^{59}$ The Jews of Portland played an active role in that aspect of the city, in some cases acting as prime movers.

The first permanent library association in the city was formed in 1864. William S. Ladd was the first contributor, Oregonian editor Harvey Scott was the first librarian, and Matthew Deady was elected the first president. ${ }^{60}$ Goldsmith attended the first organizational meeting and sat on the board of directors for several years. When Deady ran a life membership campalgn in 1875, Goldsmith purchased the fiftieth subscription. ${ }^{61}$ While Goldsmith and other prominent Jews served on the Portland Library Association board, the most active Jewish member was Morris W. Fechheimer, an attorney, who arrived in Portland in the late 1860 s and immediately entered the cultural and social life of the city. He was a free thinker and an agnostic who retained no organizational affiliation in the Jewish communtty, though he did lecture on Jewish topics. Deady, who grew very fond of Fechheimer, nominated him to the library board in 1872 , a position he held until his death in 1886.62 Fechhelmer and Deady collaborated in 1871 with the former's non-Jewish partner J. W. Whalley, in the organization of one of Portland's first literary societies, the Willamette Society. ${ }^{63}$

It was in the area of music that Portland Jews made their most important mark on the city. Despite early attempts to introduce quality vocal and orchestral music to Portland, it was not until the mid-1870s that instrumental music by local musicians received its first serious 
exposure in the city. Prussian born Simon Harris, the son of dry goods merchant Joseph Harris, established the Amateur Music Society In 1875 and was 1 ts first conductor. Fechheimer and H. Brenner, an Austrian hotel keeper, served as officers of the soclety during the first year. The soclety promoted orchestral music for the next three years, but when Harris travelled to Europe in 1878 it disbanded. In 1882 Harris returned to found the Orchestral Union, serving as its director for several years. The Amateur Music Soclety and Orchestral Union were predecessors of the Portland Symphony Orchestra, founded in $1895 .^{64}$ One of the accouterments of genteel soclety apparently was the musical recitals of the daughters of the well-heeled. Throughout the 1870 s and 1880 s, young women provided musical entertainment in the social halls, salons, and parlors frequented by the communtty's elite. Jacob Mayer's daughters, Clementine and Rose, were particularly popular. Deady wrote of the former: "She is a very charming person, talks well and sings divinely, besides being very pretty." 65

By the mid-1880s Portland Jewry was fully integrated into the economic, political, and cultural life of the city. The relatively small size of the community kept it from becoming isolated and insulated from the gentile community. Nor is there any evidence that they would have chosen to accept that way of life. Only a select few, epitomized by Goldsmith, Individualiy had an impact on the growth of the city. As a group, Portland Jews formed a small, cohesive component of the population and represented a microcosm of the city. Jewish leaders sat in the councils of government with non-Jewish leaders. The vast majority of Jews met the vast majority of other Portlanders in the day to day bustle of city life. 
With the growth of the city came an expanded social consclousness among its citizens. One observer of early Portland history noted, "Leading Jews joined in community activities on an equal footing with Gentiles." 66 But the late 1870 s and 1880 s were years of social definition and the gulf between those who had achileved a great measure of economic success and those who had not was ever widening. The notion of social class was becoming ingrained in Portland as it was in other urban centers. Differences in economic power, political power, and social status created class divisions. ${ }^{67}$ This phenomenon changed the relationship of Jews and gentiles in Portland. But its greatest impact would be felt within the Jewish community itself. Added to the three criteria of class standing was national origin. The division of the religious structure of Portland Jewry, based on nationality and cultural orientation, was compounded in the 1880 s in the social relationship between German and non-German Jews. 


\section{CHAPTER VI}

\section{AN EMERGING SENSE OF CLASS}

On October 27, 1884, "the Hebrews of this city had a grand celebration of the one hundredth anniversary of the life of Sir Moses Montefiore. ${ }^{1}$ The New Market Theater was jammed. Hundreds were turned away and the affair was equal if not superior to any ever before held in this city." 2 Jews and non-Jews alike attended the event honoring the British philanthropist. Matthew Deady, who sat on stage with the dignitaries that included the British Vice-Concul, noted that the theater "was packed from pit to dome." Attorney David Solis-Cohen and ministers Thomas Lamb Eliot of the First Unitarian Church and A. L. Lindsley of the First Presbyterian Church delivered the principle addresses.

Seven months prior to the Montefiore centenary, Portland Jews staged a gala celebration of Purim, a festive holiday celebrating freedom from oppression. Ema Friendly, Gertie Gallick, and Ralph Jacobs recreated the Biblical story of Queen Esther, and the "best orchestra Portland ever saw" performed for an audience estimated to be two-thirds Christians. ${ }^{4}$

Social interaction between Jews and non-Jews, exemplified by the Montefiore and Purim celebrations, occurred with little apparent selfconsciousness. Non-Jews partook of the festivities at the dedications of Portland's synagogues. William S. Ladd and Henry Failing were among the 300 attending the first services at Congregation Ahavai Shalom's new 
building in 1869, and the celebration was even greater twenty years later when the new Congregation Beth Israel synagogue was dedicated. 5 Jews undoubtedly foined in similar activities in the gentile community. Men and women who shared a common goal and a common class structure moved together with ease in polite society. The close ties between the wealthy and prestigious Jews and non-Jews are easily documented. Solomon Hirsch, Morris Fechheimer, Bernard Goldsmith, Philip Wasserman, and the Jacobs brothers, among others, maintained intimate business and social relationships with men like Matthew Deady, Judge Stephen Field, Henry Corbett, J. W. Whalley, and the Dolph brothers. ${ }^{6}$

Relations between the middle classes are not as easily documented. However, a relatively small Jewish population and the fact that it was dispersed residentially ${ }^{7}$ suggests that social intercourse must have occurred, if only at a minimal level. Additionally, as noted in a previous chapter, Portland's fraternal orders provided a common meeting ground for middle class Jews and non-Jews.

Whereas participation in cultural organizations was one form of association, strictly recreational and social organizations like the Alpine Club and Bicycle Club provided another kind of vehicle for intergroup activities. ${ }^{8}$ In 1873 the Progress Ciub was incorporated with "sociability" as its only stated object. All of the officers and trustees during its first year of operation were Jews, although its membership was not exclusively Jewish. During the following years the officers were mixed. The club sponsored parties, dances, and other gatherings that included Portland's soclally active citizens. Among its first gatherings was a banquet honoring wholesale merchant Isom White. ${ }^{9}$ The whirl of social activities in the 1870 s and 1880 s Indicates 
a growing sense of class in Portland. The cultural and social development of the city was promoted, in particular, by the "economic notables" of the city. 10 Historian Paul Gilman Merriam defined an "old line" soctal elite whose position was based on wealth, community service, and long-time residence, ${ }^{11}$ clearly identifying several Jewish merchants as part of the upper class strata of Portland Society.

Eighteen Portlanders, including two Jews, claimed over $\$ 100,000$ in accumulated real and personal property in 1870 . Joseph Teal was the third wealthiest resident of the city claiming property worth $\$ 338,000$, and his friend and business partner Bernard Goldsmith was eighth with $\$ 180,000$. Over the course of the next fifteen years several Jews built fortunes in wholesaling, retailing, and brokerage firms. Merriam distinguishes the "old line" elite by family residence in Portland prior to 1870, which presumably meant that men like Goldsmith, Teal, Ben Selling, the White brothers, Philip Wasserman, joseph Simon, and Louis Fleischner belonged to the group. 12

Portland's elite dominated the cultural and civic life of the city, and in the 1870 s they began to adopt a lifestyle common to the American upper class, including spending the summer season at coastal resorts, taking extended trips to Europe, and sending their children to the best schools. 13

Portland's Jewish elite participared in those activities with relish. Goldsmith sent some of his children to an exclusive high school in Benicia, California, after they attended the Bishop Scott School in Portland. 14 Simon and Ben Selling, Louis Blumauer, Henry Ach, Emil Bories, and Emmanuel Beck were among the alumn of the Portland Academy and Female Seminary, a school attended by the children of the Fafling, Couch, 
Starr, Ankeny, Coffin, and Chapman families in the 1860 s and 1870 s. $^{15}$

In the late 1870 s and early 1880 s travel to the east coast and Europe lured many of Portland's wealthy Jews. Philip Selling, his wife, and daughters travelled for over a year in Europe in the early 1880 s, leaving Ben to manage the family business. They stayed in Germany for an extended period of time visiting friends, family, and the families of other Portland Jews. ${ }^{16}$ Levi White, who dissolved his partnership with brother Isom in 1878, took an extonded trip to Europe where he met other Portlanders, including Simeon Reed, one of Portland's wealthiest non-Jewish businessmen. ${ }^{17}$

The Jewish and non-Jewish elites of the city had a great deal in common, however, there remained a barrier built on an ingrained and, during this period, largely unspoken prejudice. As in cities of the east, Jews were excluded from the very pinnacle of polite male society despite their wealth and reputation. ${ }^{18}$ In Portland's case, Jews were not invited to join the Arlington Club, "the most aristocratic club in the city." 19

The Arlington Club was founded in 1867 without a name or a constitution as a vehicle for businessmen and professionals to "fraternize for mutual enjoyment and relaxation, and to provide a meeting place for discussing their owi and Portland's destiny." The club members reorganized in 1881 and adopted the present name. ${ }^{20}$ The membership, though diverse politically, included Portland's most important non-Jewish businessmen. The men associated with the Oregon Steam Navigation Company and the west side railroad were prominent in the social club. ${ }^{21}$ A student of Portland's business community noted, "It would appear that many of the major decisions affecting Portland's business and political life 
were actually reached during 'informal' discussions held within the club's portals." 22 That means Portland's Jewish elite was not privy to at least part of the decision-making process that fostered local growth.

The reaction of men like Louis Fleischner, Sol Hirsch, and Philip Wasserman is unclear, al though there is no record of Jewish dissatisfaction over exclusion from the Arlington Club. The close social ties between Jews and non-Jews remained, but no suggestion to allow the former into the club ever received public utterance. ${ }^{23}$ Even though Cyrus Dolph and Joseph Simon were close associates, and J. W. Whalley and Morris Fechheimer were long time friends and partners, and Matthew Deady was a good friend of Bernard Goldsmith and Sol Hirsch, the Arlington Club members were never disposed to embracing the Tewish elite.

On three occasions the Arlington Club accepted a member who had one Jewish parent, however in none of the cases did the parent actively participate in Jewish communal organizations, nor did the son identify himself as a Jew. Joseph Teal, a Prussian who entered many speculative ventures with Bernard Goldsmith, married Episcopalian Mary Coleman in the mid-1850s and they raised seven children. Two of the four boys, Joseph N. and Henry, became members of the Arlington Club early in the twentieth cencury. Both were members of the Episcopalian Church. Joseph N. Teal maintained a close friendship with the Goldsmith family, and in fact received his first business training with L. Goldsmith and Company. 24

Benjamin Norden, the son of Benjamin Norden, joined the Arlington Club in the late 19 th century. The father arrived in Portland late in 
the 1850 s and soon entered the public service, servirg severai years as Multnomah County Sheriff. He was an early member of Congregation Beth Israel, but later left the congregation, probably after marrying a non-Jew. Young Benjamin, who studied medicine, was not raised as a Jew. 25

That the elder Teal did not affiliate with Jewish organizations was probably the result of his rejection of Judaism rather than exclusion by other Jews after he intermarried. Another Jew, Benjamin I. Cohen, a member of a prominent Baltimore banking family, also intermarried but remained within the community. While he did not affiliate with a congregation, he was active in the B'nai B'rith. ${ }^{26}$

The Assembly Club founded in the late 1880s, like Arlington, was a club for the social elite. It functioned less as a businessmen's meeting ground than as a convivial organization that sponsored dances and parties for its members. In 1891 it listed no Jews among the membership. 27

To argue that social anti-semitism, or even political anti-semitism lay at the heart of Jewish exclusion from the Arlington and Assembly Clubs would be an oversimplification, particularly in light of the friendships that crossed ethno-religious lines. By the mid-1870s social discrimination, particularly at the top of the social ladder, was evident in New York and other population centers of the east and midwest. The most famous incident was refusal by a Saratoga, New York resort hotel in 1877 to register Joseph Seligman, a New York financier and founder of the prestiglous Union Club of that city. ${ }^{28}$ Prior to the Seligwaii incident, discrimination against Jews occured in locales with Jewish populations, particularly in the extenston of insurance. By the 
mid-1870s, discrimination was becoming more overt. ${ }^{29}$

Julius Nodel noted that during the two decades after Jews first arrived in Portland, they encountered little hostility. With a measure of hyperbole, he contended that "on their westward trek...they discovered something more precious than gold--almost complete absence of antiSemitism." ${ }^{30}$ He suggested for Portland what historian John Higham confirmed regarding other cities with relatively large Jewish populations-that Jews found an "especially favorable status from their large share in molding the basic institutions of the city." 31

The majority of Portland's Jewish merchants and entrepreneurs operated businesses that could not be counted among the financial and commercial institutions that directly affected the economic and political development of the city. ${ }^{32}$ The members of the Arlington club, on the other hand, owned or sat on the boards of corporations that shaped the city's destiny. The fact that a Few Jews like Julius Loewenberg, Bernard Goldsmith, and Joseph Simon held directorships in some of those same corporations did not open the doors of Arlington to them. The Club members were a "company of men" who shared common interests and backgrounds which included religious preference. There can be no question that Jews were deliberately excluded from Arlington because they were Jews. However, through the 1880 s, at least, this social discrimination does not appear hostile nor motivated by political or ideological antiSemitism.

The Portland and Oregon environment was not totally free of overt ani-Jewish feelings. The Dryer incldent of 1858 and the discriminatory reports of R. G. Dun and Company illustrate that fact. Leo Samuel, a Prussian Jew who edfted and published the West Shore, a monthly booster 
magazine, recounted an Inctdent in 1877 of a 11ttle girl being taunted by her public school classmates as a Christ-killer. ${ }^{33}$ Ben Selling, in 1886, opposed the candidacy of a judge to the Oregon Supreme Court who "stated that he never knew a Jew to come into court with an honest claim." Selling noted that the candidate's chances were good if the campaign degenerated into a race fight because "there are many Jew Haters in Oregon." 34 Selling may have been correct, but it would not be until the influx of thousands of orthodox East European Jews that anti-semitism would become a major issue.

Certain stereotypes based on a "conception of Jews in the abstract" carried over into America from the European tradition. Those stereotypes antedated any real problem in America in relations between Jews and non-Jews. The use of slang terms "Shylock" and "to Jew" received common usage in the pre-Civil War era. Yet, there seemed to be no hostility or negative judgements associated with their use. 35

Portland was no different in this respect. Biblical stereotyping, generally a positive comment tying modern day Jews to the patriarchs, resulted in Portland Jews being referred to as "the children of Judah and Benjamin." 36 A much less sensitive remark, but not written with malice, came from Judge Deady after hearing a case in his courtroom. 'Heard argument for 4 hours today on a motion for an injunction in Kahn v. Salmon et Burman--Fechheimer on the one side and Simon on the other. A Jewdicial affair truly." 37

No matter what reason lay behind remarks like Deady's, by the 1880 s Portland society differentiated between Jews and non-Jews. The distinction is easily drawn on ethno-religious lines, but is less clear in the total picture of class development in the city. Portland Jews organized 
a social club that has been described as a counterpart of the Arlington Club. ${ }^{38}$ The Concordia Club became the social center of the Jewish elite in the mid-1880s. While Concordia represented the expression of a new view of themselves for Portland Jews, the city at large identified the Jewish elite somewhat differently.

The evolution of a Jewish upper class in Portland faced with exclusion from the gentile upper class conforms to Milton M. Gordon's definition of "ethclass." The ethclass is "created by intersection of the vertical stratifications of ethnicity with the horizontal stratifications of social class...." ${ }^{39}$ Thus, Solomon Hirsch's ethclass was upper class Jewish while William S. Ladd was upper class white Protestant. Although national origin played a role in distinguishing class structure among Jews, non-Jews did not as readily distinguish Jews along national 1ines.

Concordia was formed in 1878 by young Jewish men who had not yet advanced far in the white collar occupational strata. The officers during the first three years included twenty year old Moses Sichel, twenty-five year old Edward Ackerman, twenty-two year old Solomon Oppenheimer, and twenty-four year old Rudolph Goldsmith. All four were single and worked as clerks in the stores of relatives. 40 The size and composition of the Concordia Club is unknown. Likewise, the reason for its organization and its early activities are unclear. What can be learned from studying the lists of officers is the fact that they were exclusively German or native-born of German parentage. Additionally, the young clerks of 1880 exhlbited the same economic mobility that characterized the earlier generation. By the late 1880 s Moses Sichel was proprietor of a clothing store in eastern Oregon and Rudolph 
Goldsmith worked his way into a management position with Fleischner, Mayer and Company. 41

In the mid-1880s Concordia members Included many of Portland's prominent young Jewish businessmen, including Ben Selling, August Goldsmith, and Nathan Baum. It had assumed every appearance of a social club, offering activities like "full dress" balls and card games. 42 In 1887 Concordia was reorganized with its officers and trustees drawn from the ranks of the Jewish merchant elite. They included members of old Portland families like Selling and Louis Flelschner and men who arrived recently 1ike Edward Ehrman and Adolph Bissinger. ${ }^{43}$ They al1 had two things in common: business success and German background. Concordia's membership consisted of "the best Jewish citizens of Portland," 44 which, defined by the members, meant the best GermanJewish citizens. The club was listed in the 1891 Portland "400" Directory as one of four elite social institutions in the rity, with over one humdred Jewish merchants and professionals on the membership rol1. ${ }^{45}$ Only thirty-five of them can be located in the 1880 census, but the pattern of membership was clear. Eighty-six percent were born in Germany or were members of German families (Table XV). Four Alsatian Jews who were members undoubtedly were viewed as German by the rest of the community. 46

The Prussians among the membership most certainly were not Posener Jews. That assurance is based on a comparison between the membership and the "Calling and Address Iist" in the Portland "400" Directory. Polish merchants Isaac and Ralph Jacobs, owners of the Oregon City Wollen Mills, were among Portland's wealthiest Jews. They were principle financial supporters of Beth Israel in the 1887 building fund 
drive, but despite their standing in the city and inclusion on the 1 ist of 400 prominent citizens, they did not belong to Concordia. Julius Loewenberg, a stove and tin merchant, and speculator from Posen, was also included on the Calling and Address List in 1891 but not on the Concordia membership roster. A friend and business partner of the Goldsmith family, Loewenberg was one of only a handful of Jews to sit among the directors of Portland's leading financlal and non-Jewish commercial institutions. 47

TABLE XV

BIRTHPLACES OF CONCORDIA CLUB MEMBERS LOCATED IN THE 1880 CENSUS

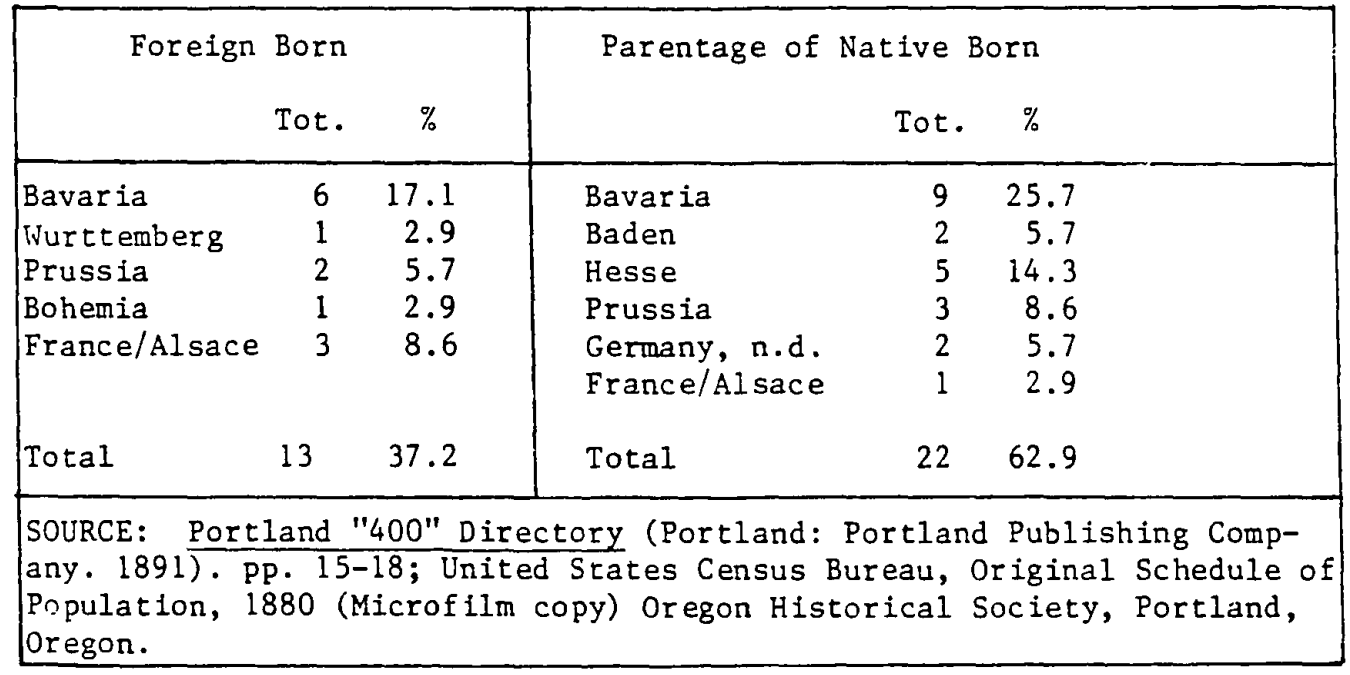

It is possible that the Jacobs and Loewenberg chose not to belong to Concordia. Several older members of the cormunity including Goldsmith, Wasserman, and Hirsch did not join the club. However, it appears more likely that the Jacobs' and Loewenberg's national origin was the determining factor. Several successful young Polish 1migrants in the 1880 s failed to become members, including boot and shoe merchant Morris Marx 
and merchant-tailors Sol Shipper and Henry $J$. White who attained the requisite business success for standing in the upper middle class, but whose Polish heritage kept them from Concordia membership. ${ }^{48}$

A visible link existed between Concordia and Congregation Beth Israel. Beth Israel members were predominantly German, and by the mid-1880s the synagogue "had become the preserve of the old German families." 49 Almost three-quarters of the Concordia membership of 1891 belonged to Beth Israel or were children of families affiliated with the congregation. Only four of the Concordia members were affiliated with Ahavai Shalom. Additionally, over half of the men who contributed to the Beth Israel building fund were members of Concordia. 50 The ties between Concordia and Beth Israel paralleled the non-Jewish community in the same way that Trinity Episcopal Church provided the religious cement that bound the Protestant social elite. The First Presbyterian and First Unitarian Churches were also important spiritual centers for Portland's gentile elite. 51

Not all of Portland's Jewish elite joined Concordia, though all of the Concordia members were part of the Jewish upper and upper middle class. The 1891 membership did not include Ben Selling, Joseph Simon, Sam Simon, or Sig Sichel, though all four were members at one time or another. Nor were all the Jews listed on the "Calling and Address List" included in Concordia. Thirty-eight Jews were viewed by the publisher of the Portland "400" Directory as part of the city's social elite, but only nine of them belonged to Concordia that year. ${ }^{52}$ The Jacobs' and Loewenberg have been discussed. Jeanette Meier, Aaron Meier's widow and matriarch of the Meler, Frank, and Hirsch familles, could not be a member because the club was for men only. As suggested above, older 
residents may have declined membership, leaving the club to the younger men in the community. Besides those mentioned, Levi White, Meyer Rosenblatt, Matthias Koshland, Jacob Fleischner, and Lev1 Hexter all appear among the " $400 "$ ", but not in the Concordia Club.

The inclusion of the Jacobs and Loewenberg among the "400" indicates that the non-Jewish portion of soclety did not clearly distinguish between German and Polish Jews, a distinction certainly drawn by the Jews themselves. The German-Polish split that caused, in part, the creation of two religious congregations in the Jewish comrunity was further institutionalized by the development of the Concordia Club. German Jews viewed their culture and heritage as far superior to that of the Poles. Because Portland's Jewish population was small and the identifiable Polish contingent remained relatively limited in the mid1880s, the division does not appear to have been as divisive as in San Francisco. 53 With a population of 16,000 Jews by 1880 , a distinct line was drawn in San Francisco between the two groups. Harriet Lane Levy, author and member of a San Francisco Prussian-Polish family, noted the difference between German and Pole in her autobiography:

That the Batern (Bavarians) were superior to us, we knew. We took our position as the denominator takes its stand under the horizontal line. "Polack" confessed second class. Why Poles lacked the virtue of Bavarians I did not understand, though I observed that to others the inferiority was as obvious as it was to is that our ashman and butcher were of poorer grade than we, because they were ashman and butcher... upon this basis of discrimination everybody agreed and acted. The birthplace of parents determined the social rank of themselves and their offspring. Birth in the kingtom of Bavaria provided entrace to the favored group, as a cradle in Poland denled it.... Many a distinguished Jewish San Franciscan's Polish background was laundered to become pure German. 54

The problem became more pronounced in Portland after 1890 when large numbers of East European and Russian Jews arrived in the city. 
Marriage between Germans and Poles during this period was unheard of. It was more likely that a Jew would marry a gentile. However, intermarriage was not an issue in Portland's Jewish community during the 19th Century. From 1776 to 1840 "outmarriages" accounted for an estimated twenty-nine percent of all marriages in the United States involving Jews, but as the Jewish population increased, the incidence of mixed marriages decreased. The Jewish leadership at midcentury uniformly opposed it, from the traditional Isaac Leeser, who noted there was no Jewish law forbidding it but felt it was wrong theologically, to the radical David Einhorn, who argued that to sanction it was "to furnish a nail to the coffin of the small Jewish race." 55

Besides Benjamin Cohen and Joseph Teal, perhaps as few as three mixed marriages occurred in Portland between 1860 and 1880,56 although the number may have been higher. We must expect that a certain number of Jews came to Portland with little or no Jewish identity. The rejection of Jewishness was far more serious in 19 th century American Jewry than intermarriage. Julius Nodel wote that "The blind desire to blend into the American melting pot prompted many to throw off completely every trait they thought might distinguish them from their Christian neighbors." 57 The rejection of Judaism and non-affiliation with Jewish organizations is euphemistically called "leakage." 58

It is impossible to know how many pioneer Jews threw off the mantle of their Jewishness in order to fully assimilate into the gentile community. One who trled was David Wittenberg who rejected his religion and maintained no ties to his Jewish background except through his relationship with some family members who continued to embrace Judaism. But Wittenberg was not able to fully divorce himself or his family from 
their heritage. Despite attendance at the Unitarian Sunday School and the family's denial of Judaism, the Wittenberg children were of ten the targets of anti-Semitic remarks by their public school classmates. 59 Intermarriage and "leakage" represented only minor problems for Portland Jewry. Class structure and the evolving tension created by development of a self-conscious elite were more immediate issues. One of the characteristics that helped stabilize class development in most large Jewish centers and insured continuity of the elite was "intramarriage." Young men and women of prominent families married each other, thus perpetuating and strengthening the bonds of class and, as important, solidifying business relationships. ${ }^{60}$ In cities like New York and San Francisco where the Jewish communities were large with correspondingly large upper and upper-middle classes, the class-bred marriages of the elite could remain pure. In Portland, even with a smaller and less well defined elite, marriages seldom occured outside of class and never outside of nationality.

In New York the children of financiers and merchant princes married, generally following informal agreements between families. Arranged marriages occurred with regularity between the Lehman, Kuhn, Schiff, Loeb, Warburg, Seligman, Hellman, Guggenheim, Strauss, and Rosenwald families. ${ }^{61}$ In San Francisco economic and social bonds were tied by the marriage of the children of the Sloss, Gerstle, Greenbaum, Lilienthal, Hecht, Levinson, Fleishhacker, Brandenstein, and Dinkelspiel families. 62

Business relationships and class standing were cemented by several marriages in Portland. Rudolph Goldsmith married Emma Fleischner, the niece of his employer Louis Fleischner; Sigmund Frank married Aaron 
Meier's daughter Fannie in 1885, a decade after becoming Meier's partner; and Levi Hexter, Philip Wasserman, Charles Lauer, Solomon Hirsch, and Julius Kraemer all married daughters or younger sisters of their business partners. ${ }^{63}$ The most intricate and far reaching intra-marriage involved the Meiers, Franks, Hirsches, Sellers, Koshlands, Dittenhoefers, Mayers, and Falks. All eight families operated successful retail or wholesale firms with branches reaching throughout Oregon, Idaho, Washington and California. ${ }^{64}$

To suggest that all those marriages were contracted or arranged by the families would be an exaggeration. The independent spirit of pioneer Jews must be considered. When Rosa Hirsch of Salem agreed to marry Sam Baer of Baker City, speculation made the rounds of Portland Jewish society that Celia Friendly, daughter of Charles Friendly, had refused him. 65

Portland Jews did not congregate together residentially during this period. In the 1850 s and 1860 s they generally lived in or near their stores, most of which were located on Front or First Streets. The only pattern that can be ascribed to them was the movement away from the business district as they accumulated more wealth. By the 1880 s Jews were found scattered throughout the city as the wealthier members of the community moved further and further west, to the Park Blocks and beyond to 16 th and 17 th Avenues. Sigmund Frank, Ben Selling, Isaac Gevurtz, and Abraham Meier lived adjacent to non-Jews Simon Benscn, Cyrus Dolph, and Henry Ladd Corbett as the 1890 s dawned. 66

Ralph and Isaac Jacobs built identical ornate mansions that rivalled the homes of William Ladd and Henry Corbett side by side in the Park Blocks in the 1880 s. $^{67}$ In the 1880 s a number of Portland's wealthiest 
businessmen moved from what is now the southwest portion of the city and built magnificent homes in the "Nineteenth Street" district in what is now Northwest Portland. Among the residents of the neighborhood were Isom White and Matthias Koshland. ${ }^{68}$

By 1887 Portland Jews were stable, affluent, and supported a well organized community structure. Few, if any, members of the community belonged to the class of the city's poor. They had evolved in thirtyfive years into a class conscious community of merchants and professionals. Portland was a cosmopolitan city with a full compliment of social and cultural organizations. The tone of the city was distinctly affected by the New England background of many of its non-Jewish leaders. ${ }^{69}$ The class-consciousness of the gentile community allowed intersection with the Jews at most, but not all levels. Thus, at middecade Portland Jewry experienced a dual class structure, one relative to the non-Jewish community and one based on intra-group relations. 
CONCLUSION

As the 1890 s approached, Portland Jewry occupied a comfortable position in the city. During the previous four decades, the Jews of the clty built a community fashioned by business acumen, mutual support mechanisms, and adaptation to the environment. Although some avenues of social expression were closed to them, they enjoyed a freedom unknown in the cities and towns of Europe. Affluence and stability characterized the community in the mid-1880s. While few enjoyed the economic success of Solomon Hirsch or Philip Wasserman, most had achieved a solid standing in the city's mercantile middle class.

The pioneer Jews, perhaps more than any other ethnic group, fit into the mold of the city. From its founding, Portland exhibited a distinctively conservative flavor that arose from the influence of New England born merchants who dominated the city's business life. As Paul Merriam has noted, Portland "had neither the bustling and exotic quality of San Francisco nor the boom and bust impermanance of bonanza cities of the mining districts." 1 Portland began as a commercial city and remained so through the 1880 s. The conservative, commercial minded German Jews formed a mercantile class which found success where they could find a stable, sober business atmosphere.

The reorganization of the Concordia Club in 1887 provides a natural point from which to review the pioneer Jews of Portland. It represented the culmination of an evolufionary process which saw Portland Jewry grow from a handful of young, aggressive entrepreneurs fighting fur survival 
in the early 1850s into a socially and ciuically active and class conscious component of the city. From the entrance of the Jews into the city they had identified their Interests with those of Portland and its non-Jewish residents. While integrating into the life of the city at every possible level, they retained an attachment to their heritage and structured their internal development in a distinctively Jewish manner. The institutions they created supported their sense of a Jewish identity, but they also reflected the dynamic frontier society the Jews encountered. The Concordia Club signalled a maturation in Portland Jewry that paralleled the changes within the gentile community. The pioneer Jews, like their non-Jewish neighbors, began to define themselves in terms of class. As William Toll stated, "The reorganization of the Concordia Club marked the debut of a self-conscious Jewish upper class, as opposed to an established patriarchy which mingled with aspiring newcomers." 2

Despite the emergence of a social elite and some division between Germans and Poles, the Jewish communtty in the mid-1880s was markedly homogenous. The issues that threatened to disrupt the community during its gestation period were met squarely and dealt with to the satisfaction of the majority. The issues of proper burial, religious ritual, charity, and social interaction which arose in all Jewish communities in America were no less apparent in Portland. After some initial struggle, a religious pluralism developed in the community that resulted in the organization of two congregations that addressed with a minimum of rancor the needs of both modernists and traditionalists.

Establishment of two B'nai B'rith lodges by 1880 served the insurance and death benefit needs of the community. More importantly, 
Creation of the second lodge indicated changing social patterns among Portland's Jews. The community was ageing and a new generation had reached adulthood. Recognition of differing social desires and interests between the younger and older members of the community convinced them that two lodges were needed.

The benevolent societies were, perhaps, the adhesive that held the community together. The First Hebrew Benevolent Association provided aid to individuals just starting out in the city. Along with discreet charity to the sick and the needy, the society insured that a poor class did not develop among the Jewish population. Mutual assistance through small loans helped stabilfze businesses and aided economic growth. Mutual support among the members of the Ladies Benevolent Society lessened the burden of life in a frontier community, particularly when husbands were out of the city on extended buying and selling trips.

In 1887 Portland Jews had every reason to be optimistic about their future. They were successful in business. With few exceptions they were embraced by the non-Jewish residents of the city. And they had built a solid foundation on which their institutions could grow and prosper. With the basic institutions of Jewish life in place, Portland's predominantly German Jews could look forward with confidence. A division between German and Polish Jews did exist in the coumunity and should not be underestimated. It was as real (particularly at the top of society) as the barrier between Arlington and Concordia. Yet, just as the Jewish and non-Jewish elites had a common meeting ground outstde of club portals, Germans and Poles met as equals in B'nai B'rith, benevolent society, and business. Additionally, the percentage of Poles In the population, while growing in the late 1870 s and 1880 s 
remained much smaller than the German contingent. Furthermore, the Poles were part of the ploneer Jewish milieu and despite cultural differences, they sought the same success and acceptance in the city as the Germans. Moreover, the split between the two groups was insignificant compared to the division between the pioneer Jews and the orthodox Russian Jews who entered the city after 1890 .

Between 1881 and the beginning of World War I in 1914 approximately two million Jews--eight times the American Jewish population in 1880-immigrated to the United States in response to official and unofficial ant1-Jewish violence in Russia and a breakdown in the traditional agrarian economy of Eastern Europe. Although most of the new immigrants remained in eastern seaboard ports of entry where they found large Jewish populations, many migrated west, either on their own or as part of a resettlement program. ${ }^{3}$ By the turn of the century Russian Jews equalled or outnumbered Portland's German Jews. Thus a new era in Portland Jewry's development began--an era that radically changed the profile of the community.

The German response to the Russians can be understood only by studying the former's development prior to 1890 . Growing with the city from its infancy, the pioneer Jews created an ethnic community that showed the affects of a frontier environment. Their institutions acquired a democratic nature which was the antithesis of the Russian experience. The pioneer Jews viewed the newcomers with shock and horror-a viewpoint which was reciprocal. To the affluent German Jews the Russians were backward and clannish, indeed, an embarrassment. The Russlans, on the other hand, were shocked by the liberalism of the GermanAmerican Jews. To the new immigrants' mind, even Congregation Ahavai 
Shalom exhibited too progressive an air. They segregated themselves, partly from a desire to be with others of like mind and partly because they were poor and had to reside where they could afford to live. The Russian settlement encompassed south Portland from Harrison Street to Curry Street and between the Willamette River and Fifth Avenue on the west side of the river. ${ }^{4}$ To the residentially dispersed German Jews, the area represented the spectre of European ghettoes.

Initially, the two groups shunned each other. The Russians formed separate congregations and established a Russian B'nai B'rith chapter. Although the immigrants followed occupations similar to those of the pioneer Jews, their occupational status fell below that of the Germans. A Russtan merchant, for example, could operate a junk store, and although classed as a merchant, his work did not carry the status of a large retail or wholesale merchant such as Louis Fleischner or Ben Selling. 5

Thus, the class distinction that appeared in the 1880s widened with the Immigration of Russian Jews. National origin was further entrenched as the determining factor in class standing in the community. However, that began to gradually change early in the twentieth century. While the pioneers would not associate socially with the Russians, many of them followed the charitable impulse and played key roles in dispensing aid to the new arrivals. Ben Selling, Sig Sichel, and Julius Lowenberg provided the leadership. Additionally, a few of the new immigrants became successful in business in a short time and turned their attention to aiding their fellow Russians. These two groups of men joined in 1910 to form the B'nal B'rith Bullding Association to provode an athletic and cultural center for the Jewish community. That step, in concert with 
the earlier consolidation of three of the four lodges of the city, initiated the first step in the erosion of a class system built on national differences ano the creation of one based on wealth. 6

These events, the German reaction to the Russians and the subsequent developments in relations between the two groups, must be seen, in part, as the products of the German Jewish experience in Portland between 1850 and 1890 . The Jews who built the original community in Portland placed a premium on stability and order. The steady and successful growth of any merchant class depends on order as does its continued well-being. The Russian Jews represented a potential disruption to the stability of the community. The Germans recognized this and addressed the problem by supplying aid and services that were designed to help in the transition to American life. This step called for no social interaction. However, men like Selling who recognized that a complete social division was also disruptive took the first tentative steps to establish social ties between the two groups. Concordia remained German and mary of the old German families remained aloof, but a new leadership would emerge in the second decade of the twentieth century. ${ }^{7}$

Speaking at the service commemorating the eightieth anniversary of the founding of Congregation Beth Israel, historian Jacob Rader Marcus praised the character, enterprise, and industry of Portland's pioneer Jews :

In no other state in the Union has the Jew adjusted himself to his environment better than nregon.... There is no other state in which the Jew reached such high positions in the political life of the commonwealth... The foundations were laid strong and deep by the pioneers who built the Jewish Community.

The pioneer German Jews came to Portland seeking economic reward. With 
some American experience behind them before they arrived, they chose not to transplant traditional European Jewish culture in their new home. While they established traditional ethnic institutions, they adapted them to the non-traditional environment of the frontier. That form of integration was not unique to the Jews, but the level of success they enjoyed was not duplicated by any other group in Portland's formative years. 
NOTES

INTRODUCTION

1 E. Kimbark MacColl, The Shaping of a City (Portland: Georgian Press, 1976), p. 1.

2 Israel Joseph Benjamin, Three Years in America, trans. Charles Reznikoff (Philadelphia: The Jewish Publication Society of America, 1956), II, 158 .

${ }^{3}$ Jacob Rader Marcus, "The Periodization of American Jewish History," Publications of the American Jewish Historical Society, 47 (195758), 125-33.

4 Oscar Handlin, "A Twenty Year Retrospective of American Jewish Historiography," American Jewish Historical Quarterly, 65 (June 1976), 297-301.

5 Ibid., 298-99.

6 William Toll, "The 'New Social History' and Recent Jewish Historical Writing," American Jewish History, 69 (March, 1980), 326.

7 Ellis Rivkin, The Shaping of Jewish History (New York: Charles Scribner's Sons, 1971), pp. 168-69, 195-97.

8 Lloyd R. Gartner, "The History of North American Jewish Communities," Jewish Journal of Sociology, 7 (June, 1965), 22-23.

9 Moses Rischin, "Introduction," in Moses Rischin (ed.), The Jews of the West: The Metropolitan Years (Waltham, 'iassachusetts: American Jewish Historical Society, 1979), pp. 5-7. For the best discussion of 
the use of quantitative sources for writing Jewish cnmmunity histories, see Marc Lee Raphael, "The Utilization of Public Local and Federal Sources for Reconstructing American Jewish Local History: The Jews of Cclumbus, Ohio," American Jewish Historical Quarterly, 65 (September, 1975), 10-35.

10 See Steven Hertzberg, Strangers Within the Gate City (Philadelphia: The Jewish Publication Society of America, 1978); Marc Lee Raphael, Jews and Judaism in a Midwestern Community, Columbus, Ohio, 1840-1975 (Columbus: Ohio State University Press, 1979).

11 See Thomas Kessner, The Golden Door (New York: Oxford University Press, 1977); Jonathan S. Mesinger, "Peddlers and Merchants: The Geography of Work in a Nineteenth Century Jewish Community," Discussion Paper Series, No. 38, Department of Geography, Syracuse University, October 1977); The Jews of the West, ed. Moses Rischin. The latter volunie contains articles on Los Angeles, San Francisco, Denver, and Portland. Neither Mesinger nor Raphael (Jews and Judaism) are used elsewhere in this study.

12 To11, "New Social History," 325-26, 333.

13 Ibid., 331.

14 Hertzberg, Strangers Within the Gate City, p. 6.

15 Kessner, The Golden Door, p. xvii.

16 Abraham J. Karp, "Introduction" in Abraham J. Karp (ed.), The Jewish Experience in America (Waltham, Massachusetts: American Jewish Historical Society, 1969), II, Ix.

\section{CHAPTER I}

1 Paul Gilman Merriam, 'Portland, Oregon, 1840-1890: A Social and 
Economic History," Diss. University of Oregon, 1971, pp. 13-15, 19-20. Merriam quotes Jesse Quinn Thornton, Oregon and California in 1848 (New York: Harper and Brothers, 1850), I, 329.

2 MacColl, The Shaping of a City, p. 17.; Merriam, "Portland, Oregon," pp. 185-86.

3 Merriam, "Portland, Oregon," pp. 20-21.

4 Ibid., pp. 21-23; Ear1 Pomeroy, The Pacific Slope (New York, 1965;

rpt. Seattle: University of Washington Press, 1973), p. 135.

5 Robert Levinson, The Jews of the California Gold Rush (New York: KTAV Publishing House, 1978), pp. 21-22; Fred Rosenbaum, Architects of Reform (Berkeley: Judah L. Magnes Memorial Museum, 1980), pp. 1-2; Peter R. Decker, "Jewish Mobility in San Francisco" in The Jews of the West, p. 12 .

6 Robert E. Levinson, "American Jews in the West," Western Historical Quarterly, 5 (July, 1974), 288.

7 Stanley Feldstein, The Land That I Show You (Garden City, New York: Anchor Press, 1978), pp. 42-53; H. G. Reissner, "The GermanAmerican Jews, 1800-1850," Leo Baeck Institute Yearbook, 10 (1965), 73-74.

8 Julius J. Nodel, The Ties Between (Portland: Temple Beth Israel, 1959), P. 7; F. H. Saylor, "Portland, Oregon--Its Founders and Early Business Men," The Oregon Native Son, 2 (1900-01), 345; Samuel M. Suwol, Jewish History of Oregon (Portland: Samuel Suwol, 1958), pp. 1-2.

9 Willamette Lodge \#2 A.F. and A. M., 1850-1950 (Portland: BedeHibbitt, Inc., 1951), n. pag.; Rudolf Glanz, The Jcws of California from the Discovery of Gold until 1880 (New York: Walden Press, Inc., 1960), pp. 160-61 . 
10 Joseph Gaston, Portland, Oregon: Its History and Builders

(Portland: S. J. Clarke Publishing Company, 1911), II, 608-09; Nodel, The Ties Between, pp. 7, 35; The Golden Book, Congregation Beth Israel Records (Microfilm copy) Oregon HistoricaI Society, Portland, Oregon.

11 United States Census, Seventh Census, 1850: Original Schedule of Population for Oregon (Microfilm copy), Oregon Historical Society; U.S. Census, 1860; Washington County Tax Rolls, 1852 (Microf 1lm copy), Oregon Historical Society; Washington County Census, 1853 (Microfilm copy), Oregon Historical Society. Portland was in Washington County until 1854 when Multnomah County was created. Merriam claims the 1850 U.S. Census listed three Jewish merchants, but there is no evidence to substantiate his figure. See Merriam, "Portland, Oregon," p. 56.

12 Gaston, Portland, Oregon, II, 144-48, 608-09; Suwol, Jewish History of Oregon, p. 2.

13 Merriam, "Portland, Oregon," pp. 186-88.

14 Levinson, "American Jews in the West," 286.

15 Merriam, "Portland, Oregon," pp. 185-217; MacCo11, The Shaping of a City, pp. 5, 17-37.

16 Moses Abrams to Isaac Leeser, July 20, 1855, Isaac Leeser Papers, Dropsie Collection, American Jewish Archives, Cincinnati, Ohio (Photocopy, Jewish Historical Society of Oregon, Portland, Oregon); U.S. Census, 1860; Levinson, Jews of the California Gold Rush, pp. 131-32.

17 The term "adult" is used here to mean 16 years of age and older. The age of 18 is used in other discussion concerning adult Jews, unless otherwise noted.

18 Gaston, Portland, Oregon, III, 494-96, and II, 234-37; Levinson, Jews of the California Gold Rush, p. 129; Leon Harris, Merchant Princes 
(New York: Harper and Row, 1979), pp. 263-65; "History of the Meier and Frank Company," typescript, Western Jewish History Center, Berkeley, n.d., pp. 1-3.

19 Information from biographles in Gaston, Portland, Oregon, vols. II and III; and U.S. Census, 1860.

20 Nodel, The Ties Between, p. 5. See Congregation Beth Israel Records, (microf $11 \mathrm{~m}$ ), Oregon Historical Society; First Hebrew Benevolent Association Records, Jewish Historical Society of Oregon; First Hebrew Ladies Benevolent Society Records, Jewish Historical Society of Oregon; Young Men's Hebrew Assoctation, Jewish Historical Society of Oregon.

21 The issues of Americanization and acculturation, and retention of a sense of Germanness are discussed in greater detail in the following chapters.

22 Paul G. Merriam, "The 'Other Fortiand': A Statistical Note on Foreign Born, 1860-1910," Oregon Historical Quarterly, 80 (Fall, 1979), 260-66. For nativity information on Portland's early non-Jewish business leaders see MacColl, The Shaping or a City, pp. 17-35.

23 Gaston, Portland, Oregon, III, pp. 593-94, 667. Additional Information on the Bergmans and Seller was taken from the U.S. Census, 1860 .

24 Merriam, "Portland, Oregon," p. 210.

25 U.S. Census, 1860; Portland City Directory, 1863 (Portland:

S. J. McCormick), pp. 27, 53, 122; Portland City Directory, 1864, p. 43. 26 The failure of many Jews to remain in Portland for more than a few years is related in great part to the level of satisfaction they felt with their lives in the city. Three-quarters of the Jews who listed $\$ 1000$ or less in property in the 1860 Census left the city during the 
1860s. Persistence--in this case, the appearance in consecutive censuses--is discussed in deta11 in Chapter IV.

27 Harvey W. Scott, History of Portland, Oregon (Syracuse: D. Mason and Company, 1890), pp. 140-41; Merriam, "Portland, Oregon," p.

214. William S. Ladd built Portland's first brick building in 1853 .

28 Nodel, The Ties Between, p. 12.

29 Lloyd R. Gartner, "History of North American Jewish Communit1es," 23; Kenneth D. Roseman, "American Jewish Institutions in their Historical Context," Jewish Journal of Sociology, 16 (June, 1974), 26; Mitchell Gelfand, "Progress and Prosperity: Jewish Social Mobility in Los Angeles in the Booming Eighties," in The Jews of the West, p. 26; Retssner, "German-American Jews, 1800-1850," 85; Rosenbaum, Architects of

Reform, pp. 4, 14-15.

30 Feldstein, The Land That I Show You, Pp. 16-19; Reissner, "German-American Jews, 1800-1850," 85; Howard Morley Sacher, The Course of Modern Jewish History, rev. ed. (New York: Delta, 1977), pp. 25-30. 31 Nachan Glazer, American Judaism, 2nd ed., rev. (Chicago: The University of Chicago Press, 1974), pp. 18-20, 34; Roseman, "American Jewish Community Institutions," 26-29.

32 Glazer, American Judaism, p. 19.

33 Abrams to Leeser, July 20, 1855.

34 The Golden Book, Beth Israel; Nodel, The Ties Between, pp. 12-13. 35 Feldstein, The Land That I Show You, pp. 44-46; Rosenbaum, Architects of Reform, p. 4 .

36 The Weekly Gleaner, San Francisco, May 28, 1858, p. 5.

37 Articles of Incorporation, 1859, Congregation Beth Israel Records, (Photocopy) Jewish Historical Society of Oregon. 
38 Leon A. Jick, The Americanization of the Synagogue, 1820-1870

(Hanover, New Hampshire: University Press of New Enğland, i976́), p.

47; J. D. Einstein, "The History of the First Russian-American Jewish

Congregation" in The Jewish Experience in America, II, 141-43; Reissner, "German-American Jews, 1800-1850," 85, 88-90; Rosenbaum, Articles of

Reform, p. 4.

39 Membership in 1861 and founders are listed in The Golden Book and The Weekly Gleaner, May 28, 1858. Members' nativity was traced in the U.S. Census, 1860 .

40 See Table I.

41 William Toll, "Fraternalism and Community Structure on the Urban Frontier," Pacific Historical Review, 47 (August, 1978), 373, 376-77.

42 Gaston, Portland, Oregon, II, 609; Harris, Merchant Princes, p.

263-64; "History of the Meier and Frank Company," p. 5.

43 Merriam, "Portland, Oregon," pp. 218-219.

44 Nodel, The Ties Between, p. 34.

45 For charity regarding burials see Minutes, Meetings of the Board of Officers, Congregation Beth Israel Records, February 27, 1873, August 6, 1873, December 8, 1873 .

46 Graenum Berger, "American Jewish Community Service, 1776-1976:

From Traditional Self-Help to Increasing Dependence on Government Support," Jetish Social Studies, 38 (Sumer-Fall, 1976) 229; Glazer, American Judaism, p. 34 .

47 Portland City Directory, 1863, p. 121. Gaston, Portland, Oregon,

III, 492-96; Node1, The Ties Between, p. 34 .

48 Benevolent Society officers in Portland C1ty Directory, 1863, p. 121. 
49 Articles of Incorporation, January 30, 1863, First Hebrew Benevolent Association Records, Jewish Histurical Society of Oregon.

50 Nodel, The Ties Between, pp. 18-19.

51 Ibid., p. 34.

\section{CHAPTER II}

1 Daily Oregonian, Portland, Oregon, January 5, 1862.

2 Calculations for Portland's population are based on figures in Merriam, "The 'Other Portland'," p. 262. Jewish population figures are based on a search of the U.S. Census, $1860,1870,1880$. Since the Census did not indicate religion of the respondent, names had to be compiled from other sources and checked against the census. However, many Jews did not affillate with Jewish organizations and could not be traced in that manner. The formula used for those not listed in other primary sources was to include those individuals with the same family name as known Jews and who were born in foreign states and followed occupations common to Jews of the era.

3 Toll, "Fraternalism," $37 \hat{\imath}-73$.

4 Merriam, "Portland, Oregon," pp. 256-58, 261-62.

5 B. Hamb urger Report, Dun and Company Records, Dun and Bradstreet Collection, Baker Library, Harvard University (photocopies, Jewish Historical Society of Oregon, Portland, Oregon); Galland, Goodman and Company Report, Dun and Company.

6 L. Goldsmith and Company Report, Dun and Company; Bernard Goldsmith Dictation, Bernard Goldsmith Papers, Bancroft Library, University of California, Berkeley.

7 A. Meier Report, Dun and Company; Harris, Merchant Princes, pp. 
264-66; Merriam,"Portland, Oregon," pp. 312-13

8 Sinsheimer Report, Dun and Company.

9 Jick, Americanization of the Synagogue, pp. ix-x.

10 Marcus Lee Hansen, The Atlantic Migration, 1607-1860 (Cambridge:

Harvard University Press, 1951). pp. 85-87, 119-22; Mack Walker, Germany and the Emigration, 1816-1885 (Cambridge: Harvard University Press, 1964), pp. 4-5, 157 .

11 Walker, Germany and the Emigration, p. 51.

12 Sacher, Course of Modern Jewish History, pp. 25-30, 53-57, 6166, 98; Lucy Dawidowicz, The War Against the Jews, 1933-1945 (New York: Holt, Rinehart and Company, 1975), pp. 32-33; Arthur Hertzberg, The Zionist Idea (New York: Atheneum, 1975), p. 22.

13 Sacher, Course of Modern Jewish History, p. 103; Ernest Hamburger, "The Jews in Public Service Under the German Monarchy," Leo Baeck Institute Yearbook, 9 (1964), 207-09; Wilhelm Harmelin, "Jews in Leipzig Fur Industry," Ibid., 9 (1964), 245-46; Herbert Strauss, "PreEmancipation Prussian Policies Towards the Jews, 1815-1847," Ibid., 11 (1966), 129; Jacob Toury, "Jewish Manual Labor and Emigration: Records from Some Bavarian Districts, 1830-1857," Ibid., 16 (1971), 48-51; Adolf Kober, "Jewish Emigration from Wurttemberg to the United States of America, 1848-1855" in The Jewish Experience in America, III, 98-100.

14 For example, see Myron Berman, Richmond's Jewry, 1769-1976

(Charlottesville: University Press of Virginia, 1979), p. 136; Raphael, "The Jews of Columbus," 13.

15 Goldsmith Dictation.

16 Oscar Handlin, "The American Scene," in A. E. Zucker (ed.), The Forty-Eighters (New York: Colurbia University Press, 1950), pp. 32-37. 
17 See biographies in Gaston, Portland, Oregon, II and III.

18 Portland City Directory, 1870, p. 21; Merriam, "Portland,

Oregon," p. 59; The Jewish Messenger, New York, October 15, 1869.

Further Information concerning Congregations Beth Israel and Ahavai

Shalom is presented in Chapter III.

19 Norton B. Stern and William M. Kramer, "The Major Role of Polish Jews in the Pioneer West," Western States Jewish Historical Quarterly, 8 (July, 1976), 326-44.

20 Julian Bartys, "Grand Duchy of Poznan under Prussian Rule," Leo Baeck Institute Yearbook, 17 ( 1972), 197-98; Strauss, "PreEmancipation Prussian Policies," 116-17.

21 The figures for German Jews include those individuals who listed their birthplace as Prussia or "Germany". Stern and Kramer claimed that many Prussians and "Germans" were actually Polish.

22 Reissner, "German-American Jews," 92-93; Sacher, Course of Modern Jewish History, p. 171.

23 Louis J. Swichkow, "The Jewish Community of Milwaukee, Wisconsin" In The Jewish Experience in America, III, 162-64; Car1 Wittke, We Who Built America, Rev. ed. (Cleveland: Western Reserve Unfversity, 1964), p. 206 .

24 Reissner, "German-American Jews," 94-95; Wittke, We Who Buiit America, p. 329.

25 Swichkow, "The Jewish Community of Milwaukee," 162-65.

26 Nathan Glazer and Danlel P. Moynihan, Beyond the Melting Pot, 2nd ed. (Cambridge: MIT Press, 1970), p. 10.

27 Nodel, The Ties Between, pp. 35-36. For reference to the German school see Minutes, Special Meetings, Beth Israel, September 24, 1865 
and Minutes, Board of Officers Meetings, Beth Israel, Augusi 25, 1872 .

28 Augustus J. Prahl, "The Turner" in The Forty-Eighters, pp.

79-109. Many Turner youth became revolutionaries in 1848 and were subsequently forced to leave Germany. The societies were transplanted to America in 1848 and espoused physical fitness and liberal principles. The slavery issue and Civil War strained the internal politics of the Turner societies and by the end of the 1870 s they resembled cultural rather than political organizations.

29 A 1 ist of officers for each organization was compiled from Portland City Directory for the years 1863-1885.

30 Thomas Ryland Robinson, "The German-Americans in Portland, Oragon, 1858-1887," Thesis Reed College 1973, p. 43.

31 Souvenir Program, Twentieth Annual Gymnastics Exhibition, 1927, Portland Social Turnverein Records, Oregon Historical Society, Portland, Oregon.

32 Node1, The Ties Between, p. 36; Alfred Powers and Howard McKinley Corning, The History of Education in Portland (Portland: WPA Adult Education Project, 1937), p. 22.

33 Minutes, Board of Officers Meetings, August 25, 1872, Beth Israel; Minutes, Special Meetings, December 21, 1873, September 30, 1874, Beth Israel.

34 Membership List, 1887, German Ald Society, Portland Social Turnverein Records; Portland "400" Directory (Portland: Portland Publishing Company, 1891), pp. 15-18; Scott, History of Portland, p. 366; Dues List, 1887, Hebrew Benevolent Society Records. 35 Lawrence J. McCaffery, The Irish Diaspora in America 
(Bloomington, Indiana: Indiana University Press, 1976), pp. 63, 66-68.

36 Petition for Divorce, December 9, 1858, Oregon Territorial Documents, State Library, Salem, Oregon (microfilm, Oregon Historfcal Society); Jacob Wasserman to Henry Wasserman, February 14, 1858 and Jacob Wasserman to Fanny Cohen, July 30, 1858, Territorial Documents. 37 Lucile Sanders McDonald, "The David Wittenberg Family" typescript, Oregon Historical Society, 1945, p.53; Nodel, The Ties Between, p. 8. The infant son of Nathan and Rosa (his second wife) Cohen is buried in the Ahavai Shalom Cemetery.

38 Gaston, Portland, Oregon, II, p. 149, III, p. 759; Goldsmith Dictation; L. Goldsmith and Company Report, Dun and Company; Tol1, "Fraternalism," 377. Max and Leopold Hirsch were not related to the Hirsch brothers (Maier, J. B., Edward, and Solomon) who immigrated to Portland in the 1850s.

39 Merriam, "Portland, Oregon," p. 38. Merriam uses the "child ladder" to trace geographic mobility. By noting in each census the birthplace and age of each child in a family, it is possible to follow the migrations of families. Determining the country of marrlage by use of the "child ladder" is not a fool-proof methodology. A couple may have married in Europe and started a family only upon reaching the Untted States. However, checking individuals in secondary sources provides enough empirical evidence to warrant use of the child ladder. 40 Information on Jacobi and Gallick is from U.S. Census, 1880. 41 Chapters III through VI chronicle the growth of Portland Jewry's organizational, economic, and class structure as well as chart Jewish Interaction with the gentile community. 


\section{CHAPTER III}

1 Benjamin, Three Years in America, II, 158.

2 Golden Book, Beth Israel; Node1, The Ties Between, Pp. 13-14, 18-20. Cohn was rabbi at Emanu-Ẽ from 1860-1889.

3 Golden Book, Beth Israel.

4 Node1, The Ties Between, pp. 20, 22-23; Joshua Stampfer, "The Life and Works of Julius Eckman," Unpublished Manuscript, (copy) Jewish Historical Society of Oregon, n.d., pp. 108, 145-48.

5 Jick, The Americanization of the Synagogue, p. 58 .

6 Hyman B. Grinstein, The Rise of the Jewish Community of New York, 1654-1860 (1946; rpt., Philadelphia: The Porcupine Press, 1976), p. 11.

7 Feldstein, The Land That I Show You, pp. 71-72; Sacher, Course of Modern Jewish History, P. 176; Allan Tarshish, "The Charleston Organ Case" in The Jewish Experience in America, II, 281-315.

8 Bertram W. Korn, American Jewry and the Civil War Rev. ed. (New York: Atheneum, 1970), p. 12; Reissner, "German-American Jews," 88-90; Grinstein, Rise of the Jewish Community of New York, p. 5 .

9 Jick, Americanization of the Synagogue, p. 183.

10 Ibid., p. 173.

11 Quoted in Nodel, The Ties Between, p. 20.

12 Ibid., pp. 20-21; Rosenbaum, Architects of Reform, pp. 13, 15; Edgar M. Kahn, "The Saga of the First Fifty Years of Congregation EmanuE1, San Francisco," Western States Jewish Historical Quarterly, III (April, 1971), 135-37.

13 Minutes, Special Meetings, Beth Israe1, October 29, 1865, 
April 18, 1869; Portland City Directory, 1879, p. 75; Nodel, The Ties Between, pp. 20-21. A shochet is a person trained in the slaughter of food animals according to Jewish law and ritual. A mohel is a circumciser. A chazan, or cantor, chants the prayers during religious services.

14 Michael A. Meyer, "Jewish Religious Reform and Wissenschaft des Judentums," Leo Baeck Institute Yearbook, 16 (1971), 21-26.

15 Nodel, The Ties Between, pp. 22-23; Rosenbaum, Architects of Reform, pp. 8-11; Stampfer, "Julius Eckman," op. 145-48, 150-51.

16 Minutes, Special Meetings, Beth Israel, October 8, 1865; Allan Tarshish, "The Board of Delegates of American Israelites, 1859-1878" in The Jewish Experience in America, II, 123-39.

17 Minutes, Special Meetings, Beth Israel, April 23, 1866. 18 See for example, Minutes, Special Meetings, Beth Israel, September 30,1866 , July 7, October 20, December 29, 1867, March 14, September 26,1869 .

19 Minutes, Special Meetings, Beth Israel, May 7, July 2, October 15, 1871 , August $11,1872$.

20 Minutes, Special Meetings, Beth Israel, March 14, August 1, September 26, 1869, April 3, 1870.

21 The Jewish Messenger, October 15, 1869; Minutes, Special Meetings, Beth Israel, March 14, 1869.

22 Members of Beth Israel were compiled from a survey of congregation minutes and subscription lists. For Ahavai Shalom members see Minute Book, 1912-1920, Congregation Ahavai Shalom Records, Jewish Historical Society of Oregon, Portland, Oregon; and The Jewish Tribune, Portland, Oregon, June 19, 1908. 
23 The Jewish Tribune, Jume 19, 1908.

24 The Jewish Messenger, October 15, 1869.

25 Minutes, Special Meetings, Beth Israel, July 7, October 6, 1867, March 29, June 21, 1868.

26 Glazer, American Judaism, pp. 37-40.

27 Quoted in Stampfer, "Julius Eckman," pp. 171-72; Merriam, "Portland, Oregon," p. 59.

28 Golden Book, Beth Israel; Toll, "Fratarnalism," 379-80; Stampfer, "Julius Eckman," p. 169. Stampfer quotes from the Ahaval Shalom Articles of Incorporation.

29 Grinstein, Rise of the Jewish Community of New York, p. 172; Glazer, American Judaism, p. 34.

30 The religious views of the three may be seen in Minutes, special Meetings, Beth Israel, July 7, October 6, 1867, March 29, 1868, September 21, 1879; Matthew Paul Deady on Bernard Goldsmith, Goldsmith Papers, Bancroft Library, University of California, Berkeley, California.

31 Minutes, Special Meetings, Beth Israel, December 21, 1873; The Reformer and Jewish Times, New York, October 19, 1877.

32 Nodel, The Ties Between, pp. 24-25.

33 Minutes, Special Meetings, Beth Israel, March 31, 1874.

34 Minutes, Special Meetings, Beth Israel, October 13, 1874.

35 Nodel, The Ties Between, p. 26.

36 Minutes, Special Meetings, Beth Israel, January 29, 1879.

37 Minutes, Special Meetings, Beth Israel, April 13, September 21, 1879.

38 Node1, The Ties Between, Pp. 28-31; Daily Oregonian, October 2, 1880. 
39 Minutes, Meetings of the Board of Officers, Beth Israel, September 24, 1880; Minutes, Special Meetings, Beth Israel, October 3, 1880. 40 Jick, Americanization of the Synagogue, pp. 115-30; Glazer, American Judaism, p. 33. Wise left the Albany, New York congregation after losing a doctrinal dispute with the membership. In 1854 he became rabbi of Congregation Bene Yeshurun in Cincinnati, Ohio.

41 Portland City Directory, 1871; Nodel, The Ties Between, p. 44.

42 Minutes, Special Meetings, Beth Israel, October 6, November 3, 1872, March 30, May 12, 1873, March 1, March 22, 1874; Minutes, Meetings of the Board of Officers, Beth Israel, July 27, 1873.

43 Minutes, Meetings of the Board of Officers, Beth Israel, JuIy $27,1873$.

44 Node1, The Ties Between, p. 44.

45 Building Fund Subscription List, 1887, Beth Israel. See Rosenbaum, Architects of Reform, p. 31 for a photograph of Emanu-E1.

46 Portland City Directory, 1871, pp. 15, 17; The Scribe, Portland, Oregon, February 18, 1921. The Scribe noted that Bories served as chazan of Ahavai Shalom for one year.

47 Minutes, Special Meetings, Beth Israel, November 12, 1882.

48 Nodel, The Ties Between, p. 53; The Jewish Tribune, June 19, 1908.

49 Grinstein, Rise of the Jewish Community of New York, pp. 131-72;

Glizer, American Judaism, p. 34.

50 Marlene Gaines, "The Early Sacramento Jewish Community," Western States Jewish Historical Quarterly, 3 (January, 1971), 66-70; John LivIngston, "The Industrial Removal office, the Galveston Project, and the Denver Jewish Community" in Jews of the West, p. 51; Rosenbaum, 
Architects of Reform, p. 15; Justin G. Turner, "The First Decade of Los Angeles Jewry" in The Jewish Experience in America, III, 70-74.

51 Gaston, Portland, Oreger, II, 663, 782; S. Rosenblatt and Company report, Dun and Company; Robert E. Levinson, "The Jews of Eugene," Lane County Historian, 13 (Spring, 1968), 3-5; U.S. Census, 1860, 1870. 52 Gaston, Portland, Oregon, II, 258-62, III, 492-96. Benevolent association officers for the years 1863-1886 are found in Portland City Directory for those years. Information on David Friedenrich is from U.S. Census, 1870.

53 Statistics on personal wealth are from U.S. Census, 1870.

54 "History of the First Hebrew Benevolent Association," First Hebrew Benevolent Association.

55 Minutes, Spectal Meetings, Beth Israel, December 12, 1867; Minutes, Meetings of the Board of Officers, Beth Israel, February 27, March 3, December 8, 1873.

56 For example see Day Book, June 15, August 13, 1885, February 20, April 16, August 6, 1886, April 14, 1887, Hebrew Benevolent Association. 57 7 Day Book, pp. 2-3. 9-13, Hebrew Benevolent Association. 58 Minutes, Meetings of the Board of Officers, Beth Israel, December 8,1875 , December 5, 1876; Balance Sheet, Apr 11 24, 1889, Treasurer's Report, Apri1, 19, 1890, Hebrew Benevolent Association. See 1ist of dues payers for $1885,1886,1887$ in Day Book, Hebrew Benevolent Assoclation.

59 Articles of Incorporation, First Hebrew Ladies Benevolent Society, June 8, 1874; Portland City Directory, 1865, p. 147.

60 William Toll, "German Women, Russian Women and the Jewish Social Network in Portland, Oregon, 1870-1930," Annual Meeting of the 
Organization of American Historians, San Francisco, April 10, 1980.

61 Minutes, Ladies Benevolent Society, March 24, September 19, 1874, March 15, 1876, November 27, 1881.

62 Article I, Section 3, Constitution, Ladies Benevolent Soclety, May $24,1874$.

63 Minutes, Ladies Benevolent Society, March 21, 1875, March 15, 1876, May 24, 1886; Minutes, Spec $1 a 1$ Meetings, Beth Israel, September 30,1886 , June 21,1874 .

64 Minutes, Ladies Benevolent Society, July 6, 1879, February

24, May 25, 1884; To11, "German Women, Russian Women ." Society of-

ficers are found in Portland City Directory from 1865-1876, 1880-1881.

65 Deady on Goldsmith, Goldsmith Papers.

Et Nodel, The Ties Between, p. 34

67 Proceedings, District Grand Lodge No. 4, 1866 (San Francisco:

District Grand Lodge No. 4, 1866), p. 74; To11, "Fraternalism," 380.

68 Edward E. Grusd, B'nai B'rith: The Story of a Covenant (Ner:

York: Appleton-Century, 1966), pp. 12-14, 20-21, 27-28; Roseman. "American Jewish Community Instit:!tions," 28-29.

69 See membership lists in Proceedings, District Grand Lodge No. 4, 1864, p. 70; Ibid., 1874, p. 90; Ibid., 1885, p. unknown. Persistence in Portland and other communities is discussed in Chapter IV.

70

Ibid., 1875, pp. 13-18.

71 Ibid., 1873, pp. 11-12; Ibid., 1874, pp. 49-50, 54 .

72 Oregon Lodge No. 65 members were found on membership lists in Proceedings, District Grand Lodge No. 4 for the years $1866-1867,1873-$ 1878, 1885. Lodge members were checked against the U.S. Census, 1860, 1870, 1880. See also Toll, "Fraternalism," 381. 
73 Proceedings, District Grand Lodge, No. 4, 1874, pp. 65-66;

Ibid., 1875, pp. 45-46.

74 Toll, "Fraternalism," 383. The average age for Lodge No. 314 members was compiled from Inttiation Book, North Pacific Lodge No. 314 , Western Jewish History Center, Berkeley, California. The Lodge No. 65 average age is from Toll, "Fraternalism," 381.

75 Toll, "Fraternalism," 384.

76 Initiation Book, North Pacific Lodge No. 314. Nativity information is from U.S. Census, 1880.

77 Toll, "Fraternalism," 381.

78 Initiation Book, North Pacific Lodge No. 314. This record contains name, age, marital status, occupation, and in some cases nativity of initiates.

79 Preambie, Article I, Section 2, Constitution, Young Men's Hebrew Association, 1879, Jewish Historical Society of Oregon, Portland, Oregon. 80 Article I, Section 2, Constitution, revised 1882, YMHA; Article VII, Section 5, By-Laws, revised 1882, YMHA.

81 Feldstein, The Land That I Show You, p. 80.

82 Membership 1ist 1882, YMHA. Members were chccked against the U.S. Census, 1880 .

83 Portland City Directory, 1873, p. 49.

84 See for example, American Hebrew News, January 19, 1894, March 3, 1899 .

85 The Concordia Club is discussed in greater detail in Chapter VI.

CHAPTER IV

1 The Jewish Messenger, New York, October 15, 1869. 
2 Portland City Directory, 1880, pp. 230-315. The business directary lists 14 Jewish stores among the 17 clothing stores. Additionally, over one-quarter of the cigar and tobacco stores, half the furniture stores, and all of the wholesale general merchandise firms were owned by Jews.

3 Feldstein, The Land That I Show You, pp. 61-69; Sacher, Course of Modern Jewish History, pp. 168-70. See also Harris, Merchant Princes. Several of the families Harris discusses fit the "peddler to prince" model.

4 Sacher, Course of Modern Jewish History, p. 170.

5 Assessment Rolls, Yamhil1 County, for the years 1855-1859, Territorial Documents; "Shemantic Emigration to the Pacific Northwest," Oregon Native Son, $2(1900-01), 374$.

6 Portland City Directory, 1865, pp. 45, 79.

7 See biographies for Solomon Hirsch, Sig Sichel, Aaron Meier, Sigmund Frank, Louis Fleischner, Simon Blumauer, Levi White, Levi Hexter, Lazarus Bettman, Jacob Fleischner, Bernard Goldsmith, Jacob Mayer, Joseph Bergman, and Max Hirsch in Gaston, Portland, Oregon, II and III.

8 All statistical information presented in this chapter is taken from the U.S. Census, $1860,1870,1880$, unless otherwise noted. 9 Gaston, Portland, Oregon, II, 261; Bernice Scharlach, "Abe Haas: Portrait of Proud Businessman," Western States Jewish Historical Quarterly, 12 (October, 1979), 5-7.

10 Emilie B. Schwabacher, Schwabacher History, typescript, pp. 1-2, Schwabacher Family Papers, University of Washington, Seattle, Washington; Bailey Gatzert Dictation, Bancroft Library, University of California, Berkeley, California. 
11 Gelfand, "Jewish Social Mobility In Los Angeles," 37-40; Hertzberg, Strangers Within the Gate C1ty, pp. 140-44; Steven Hertzberg, "Unsettled Jews: Geographic Mobility in a Nineteenth Century City:" American Jewish Historical Quarterly, 67 (December, 1977), 126.

12 Gelfand, "Jewish Social Mobility in Los Angeles," 37; Hertzberg, Strangers Within the Gate City, Pp. 143, 250. All figures for New York, Poughkeepsie, and Omaha are cited In Hertzberg.

13 Robinson, "German-Americans in Portland, Oregon," p. 25.

14 J. S. Rosenbaum and Company Report, Dun and Company; L. Goldsmith and Company Report, Dun and Company.

15 The terms used in defining occupational strata are generic and encompass a variety of occupations. Merchant, as used in this study, refers to proprietors and branch managers and includes speculators, "capitalists", peddlers, brokers, and dealers in real estate. Clerk is used to define bookkeepers, agents, salesmen, and clerks. Skilled workers include artisans like jewelers and harness makers, as well as semi-skilled occupations like butcher and barber. Professional includes teachers, rabbis, doctors, lawyers, architects, and public officials.

16 Hertzberg, Strangers Within the Gate City, p. 144.

17 Kessner, The Golden Door, pp. 44-70.

18 Hertzberg, Strangers Within the Gate City, pp. 144-45.

19 Toll, "German women, Russian Women." Toll notes a decline in fertility, by which he means a decline in child bearing, among German Jews in the 1890s.

20 Gaston, Portland, Oregon, II, 149. For information on Franklin see U.S. Census, 1880 and Portland City Directory, 1880, p. 124. 
21 U.S. Census, 1880. Information on the geographic mobility of Wise and Gerstle was obtained by use of the "child ladder."

22 Gelfand, "Jewish Social Mobility in Los Angeles," 34-36; Hertzberg, Strangers Within the Gate City, pp. 101, 236-37; Kessner, The

Golden Door, p. 49; Raphael, "The Jews of Columbus," 13.

23

Decker, "Jewish Mobility in San Francisco," 14.

24 Ibid., 14-15.

25 A. Meier Beport, Dun and Company.

26 L. Goldsmith and Company Report, Dun and Company.

27 J. S. Rosenbaum and Company Report, Dun and Company.

28 Minutes, Special Meetings, April 29, 1866, Beth Israel records; Portland City Directory, 1885, p. 400.

29 Ben Selling to "Dear Uncle," July 4, 1886, Ben Selling Papers, Oregon Historical Society, Portland, Oregon; Toll, "Fraternalism," 378.

30 Selling to Gus Winckler, January 10, 1883; Selling to Dear Folks, December 24, 1883, Selling to Julius, March 24, 1885, Selling Papers.

31 Selling to W. K. Tichenor, February 23, 1883, selling to M. K. and Son, October 23, 1884, Selling to Sig Sichel, March 28, 1885, Selling Papers.

32 Deady on Goldsmith, Goldsmith Papers; Goldsmith Dictation, Goldsm1th Papers. Teal listed his occupation in the 1870 census as Real Estate Dealer, and in 1880 as Capitalist.

33 Selling to "Dear Uncle," March 1, April 19, 1883, July 4, 1886, Selling to W. K. Tichenor, February 23, 1883, Selling Papers.

34 Selling to Julius, September 15, 1884, Selling Papers. 35 Selling to Julius, February 26, March 24, 1885, Selling Papers. 


\section{CHAPTER V}

1 Milton M. Gordon, Assimilation in American Life (New York: Oxford University Press, 1964), p. 186.

2 Willamette Lodge No. 2 , n. pag.

3 Benjamin, Three Years in America, II, 158.

4 Portland City Directory, 1880, pp. 30-45.

5 Willamette Lodge No. 2, n. pag. Officers of the various fraternal lodges were located in Portland City Directory for the years 18361885 .

${ }^{6}$ Robert E. Levinson, "The Jews of Jacksonville, Oregon," Thesis University of Oregon, 1962, pp. 44-45; Swichkow, "The Jewish Community of Milwaukee," 163-64; One Hundred Years of Freemasonry, 1857-1957 (San Francisco: Fidelity Lodge No. 120), n. pag.; Portland City Directory, 1868 , p. 29. The 1872 Directory referred to Minerva Lodge as a German lodge.

7 Albert M. Friedenberg, "A List of Jews who Were Grand Masters of Masons in Varlous States of this Country," Publications of the American Jewish Historical Society, 19 (1910), 99. See Portland City Directory for the years 1863-1885 for fraternal organization of ficers.

8 Malcolm Clark, Jr. (ed.), Pharisee Among the Philistines (Portland: Oregon Historical Soclety, 1975), I, 138, 160, II, 418.

9 Goldsmith Dictation, Goldsmith Papers.

10 Daily Oregonian, October 23, 1858.

11 Ibid., October 16, 1858.

12 Oregon Statesman, Salem, Oregon, May 4, September 21, October 16,1858 . 
13 Election Returns, 1854, City of Portland, Council Documents, Portland Archives and Records Center, Portland, Oregon.

14 Election Returns, 1854-1864, Council Documents, Portland Archives. The returns for Wasserman are incomplete, representing only Wards 1 and 3 .

15 Korn, American Jewry and the Civil War, pp. 15-55, 121-55;

Nathaniel Weyl, The Jew in American Politics (New Rochelle, New York: Arlington House, 1968), pp. 51-64; Wittke, We Who Built America, pp. 329-30. Korn gives the best account of Grant's order to expel Jews from the Tennessee Department.

16 Goldsmith Dictation, Goldsmith Papers.

17 Joseph Teal to Matthew Deady, December 5, 1859, Matthew P. Deady Papers, Oregon Historical Society, Portland, Oregon.

18 "Slavery in the Pacific Northwest," Oregon Native Son, 2 (190001), 314. The quote is from the Lane County Deed of Sale.

19 Scott, History of Portland, pp. 198-203. Scott 1 ists all the principle city officials from 1851-1889.

20 Goldsmith Dictation, Goldsmith Papers; Mayor's Annual Message, July 3, 1872, Council Documents.

21 Daily Oregonian, June 13, 1873. The newspaper reported the existence of a chapter of the Protectors of American Industry and the formation of the Anti-Chinese Protective Alliance No. 1.

22 Mayor's Veto, September 22, 1865, Council Documents; City Attorney's Opinion, September 25, 1865, Council Documents; Charles Abbot Tracey, IIT, "The Police Function in Portland, 1851-1874," Ozegon Historical Quarterly, 80 (Summer, 1979), 151.

23 Tracey, "Police Finction in Portland," 80 (Fall, 1979), 205-06. 
24 Mayor's Veto, June 21, 1873, Council Documents.

25 Quoted in Janet Baisinger, "Oregon Wooien Mills, 1850-1890,"

Graduate Project, Oregon Historical Soclety, 1980, p. 3.

26 Ibid., pp. 4, 22.

27 Malcolm Clark, Jr., "The Bigot Disclosed: 90 Years of Nativism," Oregon Historical Quarterly, 75 (June, 1974), 125.

28 Merriam, "Port1and, Oregon," p. 78.

29 Daily Oregonian, February 23, March 1, March 5, 1886; Clark, "The Bigot Disclosed," 129 ; Scott, History of Portland, p. 225.

30 Nelson Chia-Chi Ho, Portland's Chinatown (Portland: Bureau of Planning, 1978), P. 10.

31 Selling to "Dear Bernie," March 23, 1886.

32 Portland Police Arrest Records, 1875, 1880, 1885, Portland State University, Portland, Oregon. Arrests and citations noted were: Mortic Gerstle, July 24, 1880, Emil May, November 29, 1880, Philip Selling, December 21, 1880, M. Wertheimer, March 23, 1885.

33 Portland City Directory, 1879, p. 28; Ibid., 1880, p. 185; U.S. Census, 1860,1880 .

34 Tracey, "Police Function in Portland, "156-58, 291. 35 Portland City Directory, 1874, p. 65; Ibid., 1882, pp. 54-55; Clark, "The Bigot Disclosed," 126.

36 See Dun and Company reports on A. Meier, H. Wolf, Leon Ach, S. Levy, H. Sinsheimer, and Baum Brothers and Company. For the Jacobs brothers see Baisinger, "Oregon Woolen Mills," p. 22.

37 Benjamin, Three Years in America, II, 157-58.

38 Simoí Dictation, Bancroft Library, University of California, Berkeley, California. For detailed information on Simon's later career 
see MacColl, Shaping of a City.

39

Simon Dictation.

40 MacColl, Shaping of a City, pp. 62-63.

41 Tracey, "Police Function in Portland," 164-66.

42 MacCo11, Shaping of a City, pp. 62-63, 192-200.

43 Ibid., p. 61; E. Kimbark MacColl, The Growth of a City (Portland:

The Georgian Press, 1979), pp. 48-51; Gaston, Portland, Oregon, II, 14748.

44 Selling to "Friend Leo," May 21, 1886; Selling to "Dear Uncle," May 21, 1886; Selling to A. Levy, May 29, 1886; Selling to "Dear Friend," May 29, 1886; Selling to "Friend Leopold," June 19, 1886, Selling Papers. For a brief sketch of Selling's career see MacColl, Growth of a City, pp. 50-53.

45 Goldsmith Dictation, Goldsmith Papers.

46

Ibid.

47 Burt Brown Barker, "Early History: The First National Bank of Portland, Oregon," typescript, Oregon Historical Soclety, 1941, pp. 1-58. 48 Goldsmith Dictation, Goldsmith Papers.

49 Merriam, "Portland, Oregon," pp. 231-32; L. Goldsmith and Company Report, Dun and Company.

50 Merriam, "Portland, Oregon," pp. 233-39.

51 Joseph Gaston, "The Genius of the Oregon Railway System," Oregon Historical Quarterly, 7 (June, 1906), 114; Ell1s Lucia, The Saga of Ben Holladay (New York: Hastings House, 1959), p. 243; Goldswith Dictation, Goldsmith Papers.

52 Goldsmith Dictation, Goldsmith Papers; Deady on Goldsmith, Goldsmith Papers. 
53 Goldsmith Dictation, Goldsmith Papers; Irene Lincoln Poppleton, "Oregon's First Monopoly: The Oregon Steam and Navigation Company," Oregon Historical Quarterly, 9 (September, 1908), 295.

54 Goldsmith Dictation, Goldsmith Papers; Poppleton, "Oregon's First Monopoly," 295; Clark, Pharisee Among the Philistines, I, 98, 211

55 Goldsmith Dictation, Goldsmith Papers.

56 Deady on Goldsmith, Goldsmith Papers; Judge Stephen Field to Deady, April 24, 1890, December 5, 1892, Deady Papers; Clark, Pharisee Among the Philistines, II, 532, 594.

57 Deady on Goldsmith, Goldsmith Papers.

58 It Seems Like Yesterday: The History of the Oregon Bank, 18871962 (Portland: The Oregon Bank, 1962), n. pag. For Jewish members of the Board of Trade see Portland City Directory from 1875.

59 Merriam, "Portland, Oregon," pp. 144-45, 148-63.

60 Ibid., p. 151.

61 Goldsmith Dictation, Goldsmith Papers; Clark, Pharisee Among the Philistines, I, 212.

62 Morris Fechheimer to Deady, December 29, 1869, Deady Papers; Clark, Pharisee Among the Philistines, I, 69, 182, II, 442, 492.

63 Clark, Pharisee Among the Philistines, I, 13, 14. 64 Merriam, "Portland, Oregon," 148-49; Portland City Directory, 1875.

65 Selling to Parents, March 4, 1884; Selling to Parents, n.d., Selling Papers; Clark, Pharisee Among the Philistines, I, 121, 221, 276.

66 Merriam, "Portland, Oregon," 61.

67 Gordon, Assimilation in American Life, p. 40. Gordon cites 
those three criterla as the basis for defining social class.

\section{CHAPTER VI}

1 Montefiore was a British Jew who pledged his life and fortune to the amelioration of Jewish suffering around the world. For a brief sketch of his life, see Sacher, Course of Modern Jewish History, pp. 133-36.

2 Selling to Julius Wertheimer, October 27, 1884, Selling Papers.

3 Selling to Julius Wertheimer, October 27, 1884, Selling Papers; Clark, Pharisee Among the Philistines, II, p. 455.

4 selling to "Dear Folks," n.d., Selling Papers.

5 Nodel, The Ties Between, pp. 19-20, 43-44; Stampfer, "Julius Eckman," p. 170.

6 Matthew Deady's diaries and papers, in particular, illustrate the friendships between Jews and non-Jews in Portland. He had a special affinity for Goldsmith, Teal, Wasserman, Hirsch, and Fechheimer.

7 To11, "Fraternal 1sm," 383; MacColl, Growth of a City, pp. 46-48. 8 Merriam, "Portland, Oregon," p. 147. A petition to the City Council in 1880 from the Bicycle Club carried the signatures of five Jews. See Chapter $V$ of this study for more on cultural and fraternal integration of Jews and non-Jews.

9 Clark, Pharisee Among the Philistines, I, 140, 165, 201; Portland City Directory, 1873, p. 50; Ibid., 1874, p. 119; Ibid., 1875, p. 142; Ibid., 1876, p. 25. The Progress Club does not appear in the Directory after 1876.

10 Merriam, "Portland, Oregon," p. 164n.

11 Ibid., p. 167. 
12 Ibid., 165-66; U.S. Census, 1870. Merriam does include Goldsmith, Selling, and Wasserman on a partial list of "old line elite."

13 Merriam, "Portland, Oregon," PP. 170-72.

14 Goldsmith Dictation, Goldsmith Papers; Bernard Goldsmith to Deady, July 23, 1879, Deady Papers.

15 Corning and Powers, History of Education in Portland, pp. 5773; J. C. Morèland, "Pioneer Seat of Learning: The Portland Academy and Female Seminary," Oregon Native Son, 2(1900-0i); 293-94.

16 See Selling Papers for letters to his parents who were trave1ling for an extended period in Europe. For example, December 24, 1883, March 17, May 13, 1884.

17 Merriam, "Portland, Oregon," pp. 172-73; Gaston, Portland, Oregon, II, 663-64.

18 Merriam, "Portland, Oregon," pp. 62-63, 169; MacColl, Shaping of a City, pp. 175-76; MacCol1, Growth of a City, p. 3.

19 Portland "400" Directory, p. 9.

20 Arlington Club and the Men Who Built It (Portland: The Arlington Club, 1968), pp. 1, 10.

21 ibid., pp. 7, 16.

22 MacCo11, The Shaping of a City, p. 174.

23 MacCo11, Growth of a City, p. 3.

24 Arlington Club, p. 109. Henry Teal became a member in 1909.

For Joseph Teal's relationship with the Goldsmiths, see Joseph N. Teal

Diary, 1879, Joseph Nathan Teal Papers, Oregon Historical Society, Portland, Oregon.

25 Arlington Club, p. 110. Henry Teal became a member in 1909. For other information on the Nordens, see U.S. Census, 1860, 1880 . 
26 Initiation Book, North Pacific Lodge No. 314, B'nai B'rith;

It Seems Like Yesterday, n. pag.

27 Portland "400" Directory, pp. 13-14.

28 Naomi W. Cohen, "Anti-Semitism in the Gilded Age: The Jewish

View," Jewish Social Studies, 41 (Summer-Fall, 1979), 188; John Higham, Send These to Me (New York: Atheneum, 1975), pp. 148-49; Wey1, The Jew in American Politics, p. 82.

29

Cohen, "Anti-Semitism in the Gilded Age," 188-90; Morris U.

Schappes, A Documentary History of the Jews in the United States, 1654-

1875, 2nd ed. (New York: Schocken, 1976), pp. 286, 510-11.

30 Node1, The Ties Between, p. 7.

31 Higham, Send These to Me, p. 113.

32 MacColl, Shaping of a City, pp. 493-96. MacColl 1ists "100

local banks, businesses, associations and partnerships" and their principle directors. None of the businesses can be described as Jewish firms.

33 The West Shore, Portland, Oregon, January, 1876.

34 Selling to "Friend Leo," May 21, 1886; Selling to A. Levy, May 29, 1886; Selling Papers.

35 Higham, Send These to Me, pp. 117-22, 138-41.

36 Dally Oregonian, January 5, 1862.

37 Clark, Pharisee Among the Philistines, II, 442.

38 Merriam, "Portland, Oregon," p. 169; MacCo11, Shaping of a City, p. 176 .

39 Gordon, Assimilation in American Life, p. 51.

40 Portland City Directory, 1879, p. 47. All ages are for 1880 and come from the U.S. Census, 1880 . 
41 Portland City Directory, 1890, p. 391; Kathleen Kyan, The Goldsmith Company (Portland: The Goldsmith Company, n.d.), n. pag. of the officers between 1878 and 1884 who can be located in the 1880 census, ten were German or of German parentage and one was born in Denmark.

42 Selling to Jake, March 16, 1886, Selling Papers.

43 To11, "Fraternalism," 390, 390n.

44 MacCo11, Shaping of a City, p. 176; MacColl quotes from the Portland BIue Book, 1890 .

45 Portland "400" Directory, pp. 15-18.

46 Alsace is a border province between Germany and France. During the Napoleanic era, French Jews received even greater exposure through emancipation to the host society's culture than German Jews. See Sacher, Course of Modern Jewish History, pp. 53-65.

47 MacColl, Shaping of a City, Pp. 493-96. Between 1885 and 1915 Loewenberg was a director of the Merchants National Bank, Northwest Fire and Marine Insurance Company, Northwest Trading Company, and participated in several mining partnerships.

48 Henry J. White, for example, belonged to B'nai B'rith Lodge No. 314. By 1890 he was successful enough that he employed several other lodge members. See Toll, "Fraternalism," 385.

49 Toll, "Fraternalism," 390.

50 Ibid., 391 .

51 MacColl, Shaping of a City, pp. 176-78.

52 Portland "400" Directory, pp. 15-18, 31-91.

53 As early as March, 1851 San Francisco had well over 300 Jenish housebo?ds. In April two congregations formed after a heated debate 
over who would be hired as community shochet (ritual butcher). The division was along German-Polish lines. Two benevolent societies were founded that also followed national lines.

54 Quoted in Irene Nare11, Our City: The Jews of San Francisco (San Diego: Howell-North, 1981), p. 49.

55 Moshe Davis, "Mixed Marriage in Western Jewry," Jewish Journal of Sociology, 10 (December, 1968), 179-81; David Ellenson, "A Jewish Legal Decision by Rabbi Bernard Illowy of New Orleans and Its Discussion in 19th Century Europe," American Jewish History, 69 (December, 1979), 183; Korn, American Jewry and the Civi1 War, p. 3.

56 All marriages performed in Multnomah County from 1855 to 1879 have been compiled and published by the Genealogical Forum of Portland, Oregon in several installments of its publication, The Bulletin.

57 Nodel, The Ties Between, p. 32.

58 Handlin, "A Twenty Year Retrospective," 304-05.

59 McDonald, "The Wittenberg Family," p. 18.

60 Gordon, Assimilation in American Life, p. 43.

61 Levinson, Jews of the California Gold Rush, p. 31 . For an intimate look at New York's German-Jewish elite see Stephen Birmingham, Our Crowd: The Great Jewish Families of New York (New York: Harper and Row, 1967).

62 Levinson, Jews if the California Gold Rush, p. 31. Nare11, Our

City is a testimony to the Jewish elite of San Francisco.

63 Ryan, The Goldsmith Company, n. pag.; Gaston, Portland, Oregon,

I and II for Information on Julius Kraemer, Solomon Hirsch, Sigmund

Frank, Levi Hexter.

64

Harold Hirsch Interview, July 8, 1977, Jewlsh Oral History 
Project, Portland, Oregon.

65 Selling to "Dear Folks," January 28, 1884, Selling Papers.

66 MacColl, Growth of a City, pp. 47-48.

67 The Jacobs' homes are pictorially featured in Fred DeWolfe,

01d Portland (Portland: Press-22, 1976), n. pag.

68 Richard Marlett, Nineteenth Street (Portland: Oregon Historical Society, 1976), pp. 6, 79, 84 .

69 Merriam, "Portland, Oregon," pp. 183-84.

CONCLUSION

1 Merriam, "Portland, Oregon," p. 332.

2 Toll, "Fraternalism," 390.

3 Rivkin, Shaping of Jewish History, pp. 196-97; Sacher, Course of Modern Jewish History, pp. 240-60, 302-15; Moses Rischin, The Promised City (Cambridge, 1962; rpt. New York: Harper and Row, 1970), p. 270; Feldstein, Land That I Show You, pp. 118-73. In his chapter on Russian Jewish immigration Feldstein discusses the various resettlement schemes, devised primarily by the German Jews of New York. For the effects of these plans on one western community, see Ifvingston, "The Industrial Removal Office," 50-74. A brief account of IRO activities in Portland is found in William Toll, "They Built a New Home," The Historical Scribe (Spring, 1980), 1-2.

4 Maccoll, Growth of a C1ty, pp. 54-61; Nodel, The Ties Between, pp. 47-48.

5 To11, "Fraternalism," 396-98.

6 William Toll, "Mobility, Fraternalism, and Jewish Cultural Change: Portland, 1910-1930" in Jews of the West, pp. 78-80. 
7 For a discussion of changing leadership in the community, see

Ibid., pp. 75-107.

8 Quoted in The First 100 Years of B'nal B'rith Lodge, Portland, Oregon (Portland: B'nai B'rith Lodge No. 65), n. pag. 
BIBLIOGRAPHY

PRIMARY SOURCES

Manuscript Materials

Congregation Ahavai Shalom Records, Jewish Historical Society of Oregon, Portlana, Oregon.

Congregation Beth Israel Records. Articles of Incorporation (Photocopy). Jewish Historical Society of Oregon, Portland, Oregon.

Congregation Beth Israel Records (Microfilm). Oregon Historical Society, Portland, Oregon.

B'nai B'rith North Pacific Lodge \#314 Records. Western Jewish History Center, Judah L. Magnes Memorial Museum, Berkeley, California.

Matthew P. Deady Papers. Oregon Historical Society, Portland, Oregon.

R. G. Dun and Company Records. Dun and Bradstreet Collertion. Baker Library, Harvard University, Cambridge, Massachusetts (Photocopies, Jewish Historical Society of Oregon, Portland, Oregon).

First Hebrew Benevolent Association Records. Jewish Historical Society of Oregon, Portland, Oregon.

First Hebrew Ladies Benevolent Society Records. Jewish Historical Society of Oregon, Portland, Oregon.

Bailey Gatzert Dictation. Bancroft Library, University of California, Berkeley, California.

Bernard Goldsmith Papers. Bancroft Library, University of California, Berkeley, California.

Isaac Leeser Papers. Dropsie Collection. American Jewish Archives, Cincinnati, Ohio. (Photocopy, Moses Abrams to Isaac Leeser, Jewish Historical Soclety of Oregon, Portland, Oregon).

Oregon Territorial Documents (Microfilm). Oregon Historical Society, Portland, Oregon.

City of Portland. Council Documents. Portland Archives and Record Center, Portland, Oregon. 
- Pollce Arrest Records. Millar Library, Portland State University, Portland, Oregon.

Portland Social Turnverein Records. Oregon Historical Soclety, Portland, Oregon.

Schwabacher Family Papers. Susalow Library, University of Washington, Seattle, Washington.

Ben Selling Papers. Oregon Historical Society, Portland, Oregon.

Joseph Simon Dictation. Bancroft Library, University of California, Berkeley, California.

Joseph Nathan Teal Papers. Oregon Historical Society, Portland, Oregon.

United States Census office. Seventh Census, 1850. Original Schedule of Population for Oregon (Microfilm). Oregon Historical Society, Portland, Oregon.

- Eighth Census, 1860. Original Schedule of Population for Oregon. Oregon Historical Soclety, Portland, Oregon.

- Ninth Census, 1870. Original Schedule of Population for Oregon. Oregon Histor'.cal Society, Portland, Oregon.

- Tenth Census, 1880. Original Schedule of Population for Oregon. Oregon Historical Society, Portland, Oregon.

Washington County. Census, 1853 (Microfilm). Oregon Historical Socfety, Portland, Oregon.

- Tax Rolls, 1852 (Microfilm). Oregon Historical Society, Portland, Oregon.

Yamhill County. Assessment Rolls, 1855-1859 (Microfilm). Oregon Historical Soclety, Portland, Oregon.

Young Men's Hebrew Association Records. Jewish H1storical Society of Oregon, Portland, Oregon.

Published Sources, Directories

Benjamin, Israel Joseph. Three Years in America. 2 vols. Trans. Charles Reznikoff. Philadelphia: The Jewish Publication Society of America, 1956.

Clark, Malcolm Jr., ed. Pharisee Among the Philistines: The Diary of Judge Matthew P. Deady, 1871-1892. 2 vols. Portland: Oregon Historical Soclety, 1975. 
Portland City Directory. Portland: Various Publishers, 1863-1886.

Portland "400" Directory. Fortland: Portland Publishing Company, 1891.

Proceedings, District Grand Lodge No. 4. San Francisco: District Grand Lodge No. 4, 1866-67, 1873-78, 1885 .

Newspapers and Periodicals

American Hebrew News (Portland).

Daily Oregonian (Portland).

Jewish Messenger (New York).

Jewish Tribune (Portland).

Oregon Statesman (Salem, Oregon).

Reformer and Jewish Times (New Tork).

Scribe (Portland).

Weekly Gleaner (San Francisco).

West Shore (Portland).

Oral History Interviews

Harold Hirsch Interview, July 8, 1977 by Shirley Tanzer. Jewish Oral History Project, Portland, Oregon.

SECONDARY SOURCES

Books

Arlington Club and the Men tho Built It. Portland: Arlington Club, 1968 .

Berman, Myron. Richmond's Jewry, 1769-1976. Charlottesville, Virginia: Untversity Press of Virginia, 1979.

Birmingham, Stephan. Our Crowd: The Great Jewish Families of New York. New York: Harper and Row, 1967.

Dawidowicz, Lucy. The War Against the Jews, 1933-1945. New York:

Holt, Rinehart and Winston, 1975. 
De Wolfe, Fred. old Portland. Portland: Press-22, 1976.

Feldstein, Stanley. The Land That I Show You. Garden City, New York: Anchor Press, $19 \overline{978 .}$

The First 100 Years of B'nai B'rith Lodge, Portland, Oregon. Portland: B'naf B'rith Lodge $\$ 65,1966$.

Gaston, Joseph. Portland, Oregon: Its History and Builders. 3 vols. Portland: S. J. Clarke Publishing Company, 1911.

Glanz, Rudolf. The Jews of California: From the Discovery of Gold Until 1880. New York: Walden Press, Inc., 1960.

Glazer, Nathan. American Judaism. 2nd ed., rev. Chicago: The University of Chicago, 1974.

Glazer, Nathan and Daniel P. Moynihan. Beyond the Melting Pot: The Negroes, Puerto Ricans, Jews, Italians and Irish of New York City. 2nd ed. Cambridge: MIT Press, 1970.

Gordon, Milton M. Assimilation in American Life: The Role of Race, Religion, and National Origin. New York: Oxford University Press, 1964 .

Grinstein, Hyman B. The Rise of the Jewish Community of New York, 1654-1860. Philadelphia, 1946; Reprint, Porcupine Press, 1976.

Grusd, Edward E. B'na1 B'rith: The Story of a Covenant. New York: Appleton-Century, 1966.

Handlin, Oscar. Adventure in Freedom: Three Hundred Years of Jewish Life in America. New York: McGraw-Hill Book Company, Inc., 1954.

Hansen, Marcus Lee. The Atlantic Migration, 1607-1860. Cambridge: Harvard University Press, 1951.

Harris, Leon. Merchant Princes: An Intimate History of Jewish Familles Who Built Great Department Stores. New York: Harper and Row, 1979 .

Hertzberg, Arthur. The 2ionist Idea: A Historical Analysis and Reader. New York: Atheneum, 1975.

Hertzberg, Sieven. Strangers Within the Gate City: The Jews of Atlanta, 1845-1915. Philadelphia: The Jewish Publication Society of America, 1978 .

Higham, John. Send These to Me: Jews and Other Immigrants in Urban America. New York: Atheneum, 1975.

Ho, Nelson Chia-Chi. Portland's Chinatown. Portland: Bureau of Planning, 1978. 
It Seems Like Yesterday: The History of the Oregon Bank, 1887-1962. Portland: The Oregon Bank, 1962.

Jick, Leon. The Americantzation of the Synagogue, 1820-1870. Hanover, New Hampshire: University Press of New England, 1976.

Kessner, Thomas. The Golden Door: Italian and Jewish Immigrant Mobility in New York City, 1880-1915. New York: Oxford University Press, 1977.

Korn, Bertram W. American Jewry and the Civil War. Rev. ed. New York: Atheneum, 1970 .

Levinson, Robert E. The Jews of the California Gold Rush. New York: KTAV Publishing House, 1978.

Lucia, Ellis. The Saga of Ben Holladay. New York: Hastings House, 1959 .

MacCo11, E. Kimbark. The Growth of a City: Power and Politics in Portland, Oregon, 1915 to 1950. Portland: The Georgian Press, 1979.

- The Shaping of a City: Business and Politics in Portland, Oregon, 1855 to 1915. Fortland: The Georgian Press, 1976.

McCaffery, Lawrence J. The Irish Diaspora in America. Blounington, Indiana: Indiana University Press, 1976.

Marlett, Richard. Nineteenth Street. Portland: Oregon Historical Society, 1976.

Nare11, Irene. Our City: The Jews of San Francisco. San Diego: Howe11-North, 1971.

Nodel, Julius J. The Ties Between: A Century of Judaism on America's Last Frontier. Portland: Temple Beth Israel, 1959.

One Hundred Years of Freemasonry, 1857-1957. San Francisco: Fidelity Lodge No. 120, 1957.

Pomeroy, Earl. The Pacific Slope: A History of California, Oregon, Washington, Idaho, Utah, and Nevada. New York, 1965; Reprint, Seattle: University of Washington Press, 1973.

Powers, Alfred and Howard Mckinley Corning (eds.). The History of Education in Portland. Portland: WPA Adult Education Project, 1937.

Rischin, Moses. The Promised City: New York's Jews, 1870-1914. Cambridge, 1962; Reprint, New York: Harper and Row, 1970.

Rivkin, Ellis. The Shaping of Jewish History: A Radical New Interpretation. New York: Charles Scribner's Sons, 1971.

Rosenbaum, Fred. Architects of Reform: Congregational and Community 
Leadership, Emanu-E1 of San Francisco, 1849-1980. Berkeley: The Judah L. Magnes Memorial Museum, 1980.

Ryan, Kathleen. The Goldsmith Company. Portland: The Goldsmith Company, n.d.

Sacher, Howard Morley. The Course of Modern Jewish History. Rev. ed. New York: Delta, 1977.

Schappes, Morris U. A Documentary History of the Jews in the United States, 1654-1875. 2nd ed. New York: Schocken, 1976.

Scott, Harvey W. History of Portland, Oregon. Syracuse: D. Mason and Company, 1890 .

Suwol, Samuel M. Jewish History of Oregon. Portland: Samuel Suwo1, 1958.

Walker, Mack. Germany and the Emigration, 1816-1885. Cambridge: Harvard University Press, 1964.

Wey1, Nathirilel. The Jew in American Politics. New Rochelle, New York: Arlington House, 1968.

Willamette Lodge \#2 A. F. and A. M., 1850-1950. Portland: BedeHibbitt, Inc., 1951 .

Wit:ke, Carl. We Who Built America: The Saga of the Immigrant. Rev. ed. Cleveland: Western Reserve University, 1964.

Articles

Bartys, Julian. "Grand Duchy of Poznan Under Prussian Rule: Changes in the Economic Position of the Jewish Population, 1815-1848," Leo Baeck Institute Yearbook, 17 (1972), 191-204.

Berger, Graenum. "American Jewish Communal Service, 1776-1976: From Traditional Self-Help to Increasing Dependence on Government Support," Jew1sh Social Studies, 38 (Summer-Fa11, 1976), 225-46.

Clark, Malcolm, Jr. "The Bigot Disciosed: 90 Years of Nativism," Oregon Historical Quarterly, 75 (June 1974), 109-90.

Cohen, Naomi W. "Anti-Semitism in the Gilded Age: The Jewish View," Jewish Social Studies, 41 (Summer-Fal1, 19i9), 187-210.

Davis, Moshe. "Mixed Marrlage in Western Jewry: Historical Background to the Jewish Response," Jewish Journal of Soclology, 10 (necember, 1968), 177-203.

Decker. Peter R. "Jewish Mobility in San Francisco: Social Mobility 
on the Urban Frontier" in Moses Rischin (ed.), The Jews of the West: The Metropolitan Years. Waltham, Massachusetts: American Jewish Historical Soc lety, 1979. 12-23.

Eisenstein, J. D. "The History of the First Russian-American Jewish Congregation" in Abraham J. Karp, (ed.), The Jewish Experience in America, vol. 3. Waltham, Massachusetts: American Jewish Historical Society, 1969. 140-151.

Ellenson, Dav1d. " $A_{+}$Jewish Legal Decision by Rabbi Bernard Illowy of New Orleans and Its Discussion in 19th Century Europe," American Jewish History, 69 ( December, 1979), 174-95.

Frledenberg, Albert M. "A List of Jews Who Were Grand Masters of Masons in Various States in This Country," Publications of the American Jewish Historical Soclety, 19 (1910).

Gaines, Marlene. "The Early Sacramento Jewish Community," Western States Jewish Historical Quarterly, 3 (January, 1971), 65-85.

Gartner, Lloyd. "The History of North American Jewish Communities: A Field for the Jewish Historian," Jewish Journal of Sociology, 7 (June, 1965), 22-29.

Gaston, Joseph. "The Genius of the Oregon Railway System," Oregon Historical Quarterly, 7 (June, 1906), 105-32.

Gelfand, Mitchell. "Progress and Prosperity: Jewish Social Mobility in Los Angeles in the Booming Eighties" in Moses Rischin (ed.), The Jews of the West: The Metropolitan Years. Waltham, Massachuset ts: American Jewish Historical Society, 1980. 24-49.

Hamburger, Ernest. "Jews in Public Service Under the German Monarchy," Leo Baeck Institute Yearbook, 9 (1964), 206-38.

Handlin, Oscar. "A Twenty Year Retrospective of American Jewish Historiography," American Jewish Historical Quarterly, 65 (June, 1976), 295-309

- "The American Scene" in A. E. Zucker (ed.), The FortyEighters: Political Refugees of the German Revolution of 1848 . New York: Columbia University Press, 1950. 26-42.

Harmelin, Wflhelm. "Jews in the Leipzig Fur Industry," Leo Baeck Institute Yearbook, 9 (1964), 239-66.

Hertzberg, Steven. "Unsettled Jews: Geographic Mobility in a Nineteenth Century City," American Jewish Historical Quarterly, 67 (December, 1977), 125-29.

Kahn, Edgar M. "The Saga of the First 50 Years of Congregation EmanuE1, San Francisco," Western States Jewish Historical Quarterly, 3 (Apri1, 1971), 129-47. 
Karp, Abraham J. "Introduction" in Abraham J. Karp (ed.), The Jewish Exferience in America, vol. 2. Waltham, Massachusetts: American Jewish Historical Soctety, 1969. vii-xix.

Kober, Ado1f. "Jewish Emigration from Wurttemberg to the United States of America, 1848-1855" in The Jewish Experience in America, vol. 3. Waltham, Massachusetts: American Jewish Historical Society, 1969. 1-26.

Levinson, Robert E. "American Jews in the West," Western Historical Quarterly, 5 (July, 1974), 285-94.

. "The Jews of Eugene," Lane Cuunty Historian, 13 (Spring, 1968), 2-16.

Livingston, John. "Industrial Removal office, the Galveston Project, and the Denver Jewish Community" in Moscs Rischin (ed.), The Jews of the West: The Metropolitan Years. Waltham, Massachusetts: American Jewish Historical Society, 1979. 50-74.

Marcus, Jacob Rader. "The Periodization of American Jewish History," Publications of the Arcrican Jewish Historical Society, 47 (1957$58), 125-33$.

Merriam, Paul G. "The 'Other Portland': A Statistical Note on Foreign Born, 1860-1910," Oregon Historical Quarterly, 80 (Fall, 1979), 258-68.

Meyer, Michae1 A. "Jewish Religious Reform and Wissenschaft des Judentums," Leo Baeck Institute Yearbook, 16 (1971), 19-41.

Moreland, J. C. "Pioneer Seat of Learning: The Portland Academy and Female Seminary," Oregon Native Son, 2 (1900-01), 286-94.

Poppleton, Irene Lincoln. "Oregon's First Monopoly: The Oregon Steam Nevigation Company," Oregon Historical Quarterly, 9 (September, 1908), 274-304.

Prahl, Augustus J. "The Turner" in A. E. Zucker (ed.), The FortyEighters: Political Refugees of the German Revoluticn of 1848 . New York: Columblá Unfversity Priess, 1950. 79-109.

Raphael, Me $\cdots$ Lee. "The Utilization of Public, Local and Federal Sources for Reconstructing American Jewish Local History: The Jews of Columbus, Ohio," American Jewish Historical Quarterly, 65 (September, 1975), 10-35.

Reissner, H. G. "The German American Jews, 1800-1850," Leo Baeck Institute Yearbook, 10 (1965), 57-116.

Rischin, Moses. "Introduction" in Moses Rischin (ed.), The Jews of the West: The Metropolitan Years. Waltham, Massachusetts: American Jewish Historical Sociecy, 1979. 5-11. 
Roseman, Kenneth D. "American Jewish Community Institutions in Their Historical Context," Jewish Journal of Sociology, 16 (June, 1974), $25-38$.

Saylor, F. H. "Portland, Oregon--Its Founders and Early Business Men," Oregon Native Son, $2(1900-01), 329-57$.

Scharlach, Bernice. "Abe Haas: Portrait of a Proud Businessman," Western States Jewish Historical Quarterly, 12 (October, 1979), 3-24.

"Shemantic Emigration to the Pacific Northwest," Oregon Native Son, 2 (1900-01), 374 .

"Slavery in the Pacific Northwest," Oregon Native Son, 2 (1900-01), 314.

Stern, Norton B. and William M. Kramer. "The Major Role of Polish Jews in the Pioneer West," Western States Jewish Historical Quarterly, 8 (July, 1976), 326-44.

Strauss, Herbert. "Pre-Emancipation Prussian Policies Towards the Jews, 1815-1847;" Leo Baeck Institute Yearbook, 11 (1966), 107-36.

Swichkow, Louis J. "The Jewish Community of Milwaukee, Wisconsin, 18601870" in Abraham J. Karp (ed.), The Jewish Experience in America, vol. 3. Waltham, Massachusetts: American Jewish Historical Society, 1969. 152-76.

Tarshish, Allan. "The Board of Delegates of American Israelites, 18591878" In Abraham J. Karp (ed.), The Jewish Experience in America, vol. 2. Waltham, Massachusetts: American Jewish Historical Society, 1969. 123--39.

- "The Charleston Organ Case" in Abraham J. Karp (ed.), The Jewish Experience in America, vol. 2. Waltham, Massachusetts: American Jewish Historical Society, 1969. 281-315.

To11, William. "Fraternalism and Community Structure on the Urban Frontier: The Jews of Portland, Oregon--A Case Study," Pacific Historical Review, 47 (August 1978), 369-403.

- Mobility, Fraternalism, and Jewish Cultural Change: Portland, 1910-1930" in Moses Rischin (ed.), The Jews of the West: The Metropolitan Years. Waltham, Massachusetts: American Jewish Historical Society, 1979. 75-106.

- "The 'New Social History' and Recent Jewish Historical Writing," American Jewish History, 69 (March, 1980), 325-41.

$\frac{1-2 .}{1-}$ "They Built a New Home," Historical Scribe, (Spring, 1980),

Toury, Jacob. "Jewish Manual Labor and Emigration: Records from Some Bavarian Districts, 1830-1857," Leo Baeck Inst1tute Yearbook, 16 
$(1971), 45-62$.

Tracey, Charles Abbot, III. "The Police Function in Portland, 18511874 ," Oregon Historical Quarterly, 80 (Spring, Sunmer, Fall, 1979), 5-29, 134-69, 286-322.

Turner, Justin G. "The First Decade of Los Angeles Jewry: A Ploneer History, 1850-1860" in Abraham J. Karp (ed.), The Jewish Experience in America, vol. 3. Waltham, Massachusetts: American Jewish Historical Society, 1969. 63-76.

Unpublished Works

Baisinger, Janet. "Oregon Woolen Mills, 1850-1980." Graduate Project, Oregon Historical Society, 1980.

Barker, Burt Brown. "Early History: The First National Bank of Portland, Oregon." Typescript, Oregon Historical Society, 1941.

"History of the Meier and Frank Company." Typescript, Western Jewish History Center, Juda' L. Magnes Memorial Museum, n.d.

Levinson, Robert E. "The Jews of Jacksonville, Oregon." Master's Thesis, University of Oregon, 1962.

McDonald, Lucile Sanders. "The David Wittenberg Family." Typescript, Oregon Historical Society, 1945.

Merriam, Paul Gilman. "Portland, Oregon, 1840-1890: A Social and Economic Hfstory." Ph.D. Dissertation, University of Oregon, 1971.

Robinson, Thomas Ryland. "The German-Americans in Portland, Oregon, 1858-1887." Bachelor's Thesis, Reed College, 1973.

Stanpfer, Joshua. "The Life and Works of Julius Eckman." Unpublished Manuscript. (Copy) Jewish Historical Society of Oregon, n.d.

Toll, William. "German Women, Russian Women, and the Jewish Social Network in Portland, Oregon, 1870-1930." Annual Meeting of the Organization of American Historians, San Francisco, April 10, 1980. 